\title{
A esterilização cirúrgica feminina no Brasil, controvérsias na interpretação e desafios na aplicação da Lei 9263.
}

Sergio Toshio Yamamoto

Dissertação apresentada ao Programa de Pós - Graduação em Saúde Pública para obtenção do título de Mestre em Saúde Pública.

Área de concentração: Saúde, Ciclos de vida e Sociedade.

Orientadora: Prof $^{\mathrm{a}} \mathrm{Dr}^{\mathrm{a}}$. Augusta Thereza Alvarenga.

São Paulo 
É expressamente proibida a comercialização deste documento, tanto na sua forma impressa como eletrônica. Sua reprodução total ou parcial é permitida exclusivamente para fins acadêmicos e científicos, desde que na reprodução figure a identificação do autor, título, instituição e ano da tese/dissertação. 
Dedico este trabalho aos meus pais, Toshiko e Ryoiti (in memorian), aos meus irmãos e em especial a minha avó Kin Sakuma (in memorian) que nunca deixaram de acreditar na minha caminhada em busca de meu sonho, a de obter minha graduação médica.

À minha querida esposa Cristina, pelo incentivo e apoio nos momentos de dificuldades e a compreensão pelos períodos de minha ausência.

Aos meus filhos Rafael e Letícia, que me proporcionaram muitas alegrias e a dose de estímulo redobrado para prosseguir em busca dos meus sonhos. 


\section{AGRADECIMENTOS}

À Prof ${ }^{a} \operatorname{Dr}^{\mathrm{a}}$ Augusta Thereza Alvarenga, pela dedicação e incansável empenho na orientação desta dissertação.

À Prof ${ }^{a}$ Paula Licursi Prates, pelos incentivos e seus inestimáveis auxílios durante toda esta caminhada.

À Colega de pós-graduação, mestranda Maria Cristina Pires, por compartilhar muitos momentos até a etapa final deste trabalho.

Aos professores da pós-graduação especialmente a Prof ${ }^{a} \mathrm{Dr}^{\mathrm{a}}$ Maria da Penha Vasconcellos pelo constante incentivo.

Aos funcionários Leandro Cleto e lara Aparecida de Macedo do Departamento de Saúde Materno-Infantil pela sua presteza e ajuda durante a realização deste trabalho.

À Prof ${ }^{\mathrm{a}} \mathrm{Dr}^{\mathrm{a}}$ Marcia Maria de Aquino, Diretora da Divisão Médica do Hospital Maternidade Leonor Mendes de Barros pelo incentivo e compreensão.

Às secretárias da Diretoria da Divisão Médica do Hospital Leonor Mendes de Barros, Lourdes Marico Amano Kimura e Maria de Lourdes Claro pelo apoio e colaboração.

A todos os profissionais médicos, enfermeiros, psicólogos e assistentes sociais do Hospital Maternidade Leonor Mendes de Barros que colaboraram com suas entrevistas.

A todos os amigos e médicos residentes do Hospital Maternidade Leonor Mendes de Barros pelo apoio e incentivo. 
À Supervisora Técnica de Saúde da Penha, Janice Olivia Galvane por sua colaboração em permitir o trabalho de campo em suas unidades básicas de saúde.

Aos profissionais da Supervisão Técnica de Saúde da Penha, médicos, psicólogos, enfermeiros e assistentes sociais que colaboraram com suas entrevistas.

À Rachel Altman que prontamente fez a transcrição das minhas entrevistas.

Às pessoas que indiretamente deram suporte para a realização deste trabalho Maria Damiana e Luzinete de Jesus.

A todos aqueles cujos nomes eu deixei de citar, mas ao lerem estas palavras incorporarão meus sinceros agradecimentos. 
YAMAMOTO, S.T. A esterilização cirúrgica feminina no Brasil, controvérsias na interpretação e desafios na aplicação da Lei 9263. [Dissertação de Mestrado] São Paulo: Faculdade de Saúde Pública da USP; 2011.

\section{RESUMO}

Introdução: A esterilização cirúrgica foi historicamente considerada como importante problema de Saúde Pública, dada sua alta prevalência em nosso país. Em 2006 (MS), era o método contraceptivo mais utilizado, entre as mulheres de 15 a 49 anos, sendo sua prevalência de 29,1\%. Esta prática aconteceu no Brasil em um cenário de clandestinidade, como crime e conduta antiética, salvo em algumas situações de risco de vida, acompanhadas de distorções como a cesárea para fins exclusivos de esterilização. A regulamentação da Lei 9263/96 representou abertura ao direito e ao acesso das mulheres à esterilização cirúrgica. No entanto, seu texto foi considerado ambíguo, induzindo a diferentes interpretações por profissionais, notadamente em relação a sua aplicação a mulheres muito jovens. Objetivos: Identificar como profissionais de saúde conhecem e interpretam a Lei 9263/96; que artigos da Lei apresentam controvérsias na sua interpretação e aplicação; as questões éticas, morais, sociais e clínicas relacionadas com tais controvérsias e que desafios se colocam para cumprimento da mesma como resposta aos direitos das mulheres. Procedimento Metodológico: Pesquisa de natureza qualitativa, com entrevistas de 27 profissionais de saúde da cidade de São Paulo. $\mathrm{Na}$ interpretação das narrativas foi utilizada a Análise de Discurso. Resultados: Nos discursos dos vários profissionais há um reconhecimento positivo de que a Lei se apresenta como disciplinadora da prática médica, retirando o procedimento de sua condição de ilegalidade. São identificadas controvérsias em relação ao texto da Lei, sobretudo no que se refere à idade de 25 anos ou dois filhos vivos e, também, à sua realização no momento do parto. Os discursos permitem revelar a complexidade de que se reveste a aplicação da lei, tendo em vista o peso que os critérios sociais assumem no processo de aprovação e execução da esterilização, na medida em que a mesma passa a caracterizarse, em nível de serviços de saúde, como um procedimento ao mesmo tempo clínico e de intervenção social. Conclusão: Constata-se a importância da esterilização cirúrgica estar inscrita de fato no contexto do planejamento familiar, 
garantindo previamente 0 acesso às informações sobre os diferentes métodos, seus benefícios e riscos, colocando- se a esterilização como último recurso. As controvérsias e desafios descritos no trabalho apresentam contribuições ao abrirem novas perspectivas para o entendimento do problema e melhor aplicação da Lei.

Palavras- chave: lei 9263/96, esterilização feminina, esterilização masculina, direitos sexuais, direitos reprodutivos, políticas de saúde. 
YAMAMOTO, S.T. Female surgical sterilization in Brazil -

controversies in the interpretation and challenges in application of

Law 9263/96. [Master's Degree thesis] São Paulo: School of

Public Health USP,

2011.

\section{ABSTRACT}

Introduction: Surgical sterilization has historically been regarded as an important public health problem given its high incidence in Brazil; according to the Ministry of Health, in 2006 it was the most widely used contraceptive among women from 15 to 49 years of age, and accounted for $29,1 \%$ of the cases. In Brazil this practice was done clandestinely, like a crime or unethical conduct, except in situations involving risk of life, and even in these cases there were distortions - such as cesareans performed for the sole purpose of sterilization. The regulation of Law 9263/96 represented the establishment of the right of women to have access to surgical sterilization. However its text was considered ambiguous, leading to different interpretations by professionals, especially with respect to its application to very young women. Objectives: To identify how health professionals know and interpret Law 9263/96; which articles of the Law are controversial in their interpretation and application of the Law; the ethical, moral, social and clinical questions related to such controversies and which challenges have to be met to comply with said law to ensure Women's Rights are attended. Method: qualitative research, involving interviews with 27 health professionals from São Paulo. Content's Analysis was used to interpret the narratives. Results: In their interviews many professionals recognize that the law disciplines this medical practice, removing its illegal stigma. They also identify controversies in relation to the Law, especially as regards the age of 25 or two living children and of the procedure being done at the time of delivery. The discourses reveal the complexity that law enforcement is covered around. The sterilization carries strong social approval criteria to be performed, at the same time that (at the Health Service level) sterilization becomes a clinical and social intervention procedure. Conclusion: The importance of surgical sterilization as a factor to be entered into the context of family planning is shown clearly, thereby ensuring access to advanced information about the different methods, their benefits and risks, and placing sterilization as a last resort. 
The controversies and challenges described in the paper show contributions to opening new perspectives for the understanding of the problem and improved enforcement of the Law.

Keywords: law 9263/96, female sterilization, male sterilization, sexual rights, reproductive rights, health policies. 


\section{ÍNDICE}

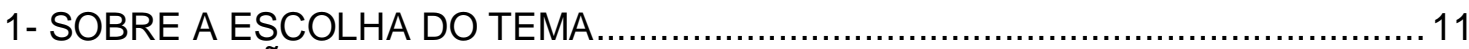

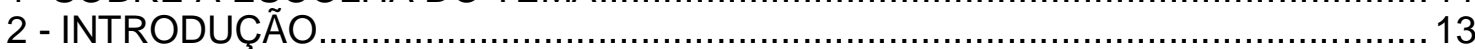

2.11 - A esterilização cirúrgica como uma questão social e de Saúde Pública ........13

2.1.1 - A esterilização cirúrgica em homens e mulheres no contexto da

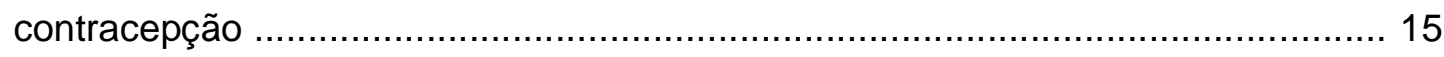

2.1.2 - A esterilização cirúrgica precoce e implicações para a saúde pública ...........17

2.22 - A clandestinidade como cenário da esterilização cirúrgica antes da regulamentação da lei

2.33 - A contracepção no contexto dos Direitos Sexuais e Direitos Reprodutivos

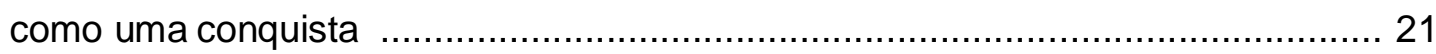

2.44 - A Regulamentação da Lei 9263/96 como reconhecimento dos .....................26

Direitos Sexuais e Direitos Reprodutivos no Brasil ............................................... 26

2.55 - Sobre a regulamentação da Lei 9263/96 e controvérsias do texto oficial: divergências na interpretação e desafios na aplicação da lei 9263/96 como relevante

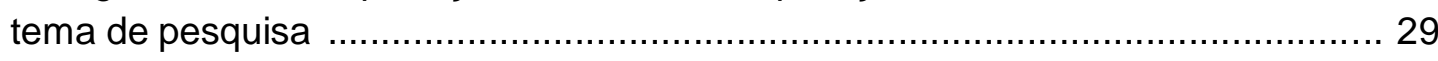

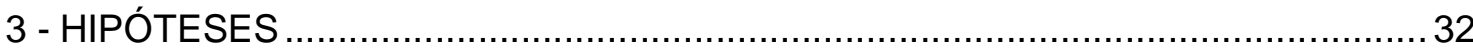

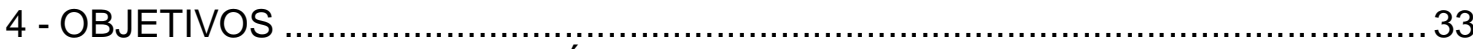

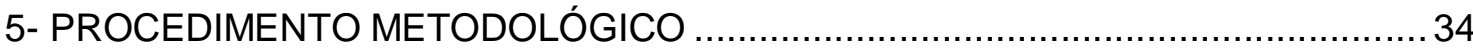

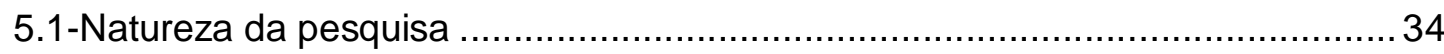

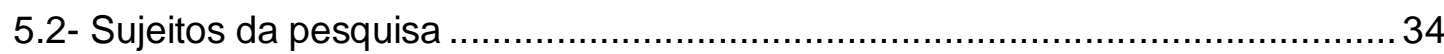

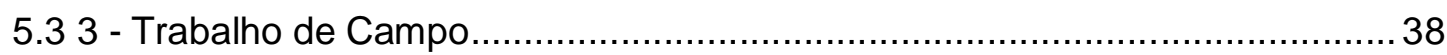

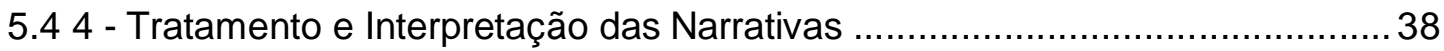

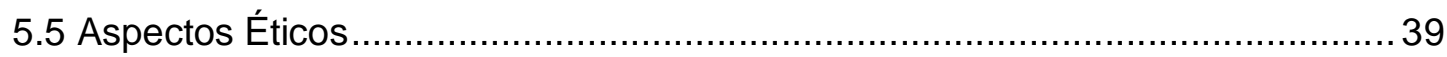

6. ANÁLISE DOS DISCURSOS DE PROFISSIONAIS DA SAÚDE ...........................40

6.11 Caracterização dos sujeitos de pesquisa..................................................... 40

6.2 Concepção dos profissionais sobre a esterilização como método contraceptivo

6.2.1 A esterilização como opção de método contraceptivo...................................... 46

6.2.2 A esterilização como último recurso.............................................................. 49

6.33 Concepção dos profissionais sobre a regulamentação da lei 9263/96 ….........54

6.3.1 A regulamentação como disciplinadora da prática médica ...............................54

6.3.2 A regulamentação como ampliadora do acesso à esterilização cirúrgica .........58

6.4 4 A esterilização cirúrgica na prática dos serviços de saúde ............................... 63

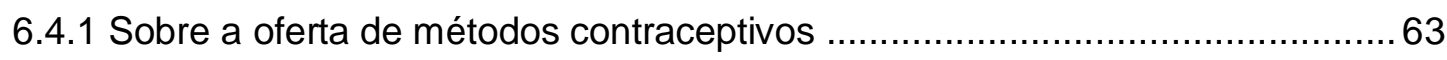

6.4.2 O processo para aprovação da esterilização pelas equipes .............................65

6.4.3 Sobre o significado da equipe multidisciplinar no processo de aprovação da esterilização 
6.4.4 Motivos pelos quais casais, homens ou mulheres escolhem a esterilização cirúrgica

6.4.5 Critérios definidores para as tomadas de decisões pelas equipes.

6.4.6 Sobre concordâncias e divergências no processo de aprovação pelas equipes.

6.4.7 A regulamentação da esterilização cirúrgica contemplando o desejo do casal como um direito: do uso ao abuso

6.5 Das ambiguidades e das controvérsias da lei 9263/96 aos dilemas nas decisões

6.5.1 Sobre a esterilização em casal jovem com idade inferior a 25 anos e dois filhos vivos, neste caso mulher com 21 anos, com relacionamento conjugal estável.......103

6.5.2 A respeito da situação de solteiro(a) sem filhos e com idade superior a 25 anos.

6.5.3 A respeito de homem ou mulher com mais de 2 filhos e mais de 25 anos sem parceiro atual 124

6.5.4 Sobre a situação de momento do parto com processo aprovado, ter indicação médica de parto cesárea e a mulher não ter duas ou mais cesáreas anteriores ... 132

6.6 Sobre o aperfeiçoamento da lei 9263/96 no discurso dos profissionais ........... 143

7- CONSIDERAÇÕES FINAIS ............................................................... 176

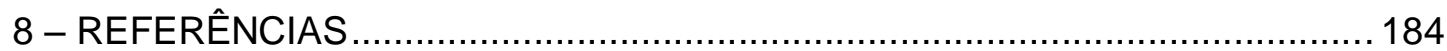

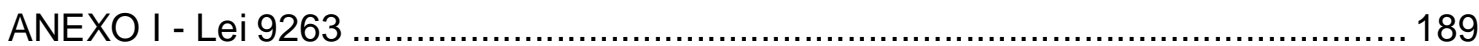

ANEXO II - Roteiro Temático ....................................................................... 195

ANEXO III: Termo de Consentimento Livre e Esclarecido ........................................ 199 


\section{1- SOBRE A ESCOLHA DO TEMA}

Em 1988 apresentamos no Congresso Mundial de Ginecologia e Obstetrícia realizado no Rio de Janeiro uma casuística de 20 casos de reversão de laqueadura tubária, com resultado de 70\% de gestações após cirurgia de re- anastomose tubária com protocolo rigoroso de triagem, através de laparoscopia prévia, estudo esse desenvolvido no Hospital Brigadeiro em São Paulo (Hospital Público).

Naquela época a esterilização cirúrgica era realizada em um contexto onde não havia uma legislação específica. Somente em 1996 o procedimento foi regulamentado através da Lei 9263 (anexo I) e já se observava, naquela ocasião uma demanda para a re-canalização tubária por arrependimento, provenientes das diversas regiões do país. Um caso marcante de arrependimento foi o fato, que me recordo até hoje, de uma mulher de 36 anos, com cinco filhos vivos de três parceiros de uniões anteriores e com cinco partos cesáreas anteriores, ter procurado o serviço para essa finalidade, determinada a "propiciar um filho" a qualquer custo ao parceiro atual, jovem de 28 anos. Apesar da orientação sobre os riscos, inclusive de vida, ela insistia em fazer a reversão da laqueadura tubária. Inconformado e perplexo apresentei à equipe o caso, que foi discutido e decidido por atender à solicitação da mulher, mesmo com a minha opinião desfavorável, pois o desejo da mulher tinha amparo previsto no nosso código de ética médica. Felizmente para ela, "o sacrifício" teve um final feliz e a mesma engravidou. Naquele contexto, o que me chamou atenção foi que o arrependimento da esterilização cirúrgica pode acometer também as mulheres maduras e multíparas dispostas a ter uma possibilidade de gerar um filho a qualquer custo, a exemplo do caso descrito, cuja expressão permanece viva em minha memória "Posso morrer, mas quero fazer a cirurgia para dar um filho a este homem".

A regulamentação da Lei 9263 em 1996 teve o inegável mérito de propiciar o direito e o acesso das mulheres à esterilização cirúrgica, entretanto, o 
controverso texto da lei traz desafios e conflitos entre os profissionais de saúde que atuam na aplicação da lei pela não concordância com alguns critérios da mesma. A alta prevalência da esterilização cirúrgica em nosso meio e a prática do procedimento em mulheres jovens é motivo de preocupações quanto ao futuro arrependimento, o que levou a interessar-me pelo tema, como objeto da minha dissertação de mestrado. 


\section{2 - INTRODUÇÃO}

\section{1 - A esterilização cirúrgica como uma questão social e de Saúde Pública.}

O primeiro relato de esterilização tubária consta de sua ocorrência, em Toledo, no Estado de Ohio, Estados Unidos da América em 1880, realizado por Samuel Smith Lungren, durante um parto cesárea (PETERSON, 2008).

De acordo com GLINA e col. (1986), a primeira vasectomia foi realizada em cães por Sir Astley Cooper em 1823. Apenas em 1897, Ochsner realizou a cirurgia em pacientes com objetivo de curar a hipertrofia prostática. A partir de 1899 este mesmo autor propôs o uso da vasectomia para esterilizar criminosos para que não transmitissem defeitos genéticos à sua prole.

A laqueadura tubária, por envolver aspectos políticos, éticos, religiosos, demográficos e sociais é tema polêmico e emergente desde a primeira intervenção (CUNHA e col., 2007).

Até a década de 1960, as esterilizações sofreram muitas críticas e sua utilização permaneceu limitada. Entretanto, a partir de 1970, foi ganhando popularidade e seu emprego se espalhou pela Europa, Estados Unidos, Ásia, América Latina. Nos Estados Unidos, em 1992, entre as mulheres casadas em idade reprodutiva, $14 \%$ dos parceiros se submeteram à vasectomia e $24 \%$ delas foram esterilizadas; na Europa, o percentual de mulheres laqueadas nessa mesma condição era bem menor: $6 \%$ na França, $7 \%$ na Inglaterra e 4\% na Itália (FORREST, 1993).

Por muitos anos a prática da esterilização no Brasil aconteceu em um cenário de clandestinidade, na medida em que era interpretada, do ponto de vista jurídico, como ofensa criminal, com base no Código Penal de 1940, Artigo 29, Parágrafo 2. III, e segundo o Código de Ética Médica, a realização da esterilização cirúrgica fora proibida até 1988, salvo em algumas situações especificas de risco de vida (BERQUÓ e CAVENAGHI, 2003; CARVALHO e col., 
2007).

Esse contexto de ilegalidade contribuiu para que se verificassem várias distorções na prática da esterilização como, por exemplo, no caso da laqueadura, a realização de cesariana apenas para encobrir a cobrança adicional da mesma, assim como a sua realização em mulheres muito jovens e com poucos filhos, sob maior risco de arrependimento (HARDY e col.; VIEIRA, 1994, 1998).

Foi somente em 1997 que o Ministério da Saúde estabeleceu as regras para a realização da esterilização cirúrgica no Sistema Único de Saúde (SUS), através da Portaria no. 144/97que regulamentou os parágrafos correspondentes à esterilização na Lei ํo. 9.263, sancionada em 12 de janeiro de 1996. Alguns obstáculos no cumprimento da lei foram observados como, por exemplo, a falta de insumos adequados para oferecimento de todos os métodos contraceptivos, clientelismo eleitoral, além da resistência de uma parcela dos profissionais de saúde em aceitarem os critérios estabelecidos pela lei, especialmente no que se refere a idade mínima, considerada muito jovem, com maior possibilidade de arrependimento (CARVALHO e col., 2007).

Segundo Alvarenga e Schor (1998), a lei 9263 passou a ser considerado um avanço do ponto de vista dos direitos reprodutivos quando da sua regulamentação, uma vez que se pretendia garantir aos cidadãos o direito ao controle da fecundidade de forma segura, com o apoio do Estado por meio do Sistema Único de Saúde (SUS).

Desde que a realização da esterilização cirúrgica foi regulamentada, houve um grande aumento nos registros de laqueaduras e vasectomias realizadas, o que pode ser constatado através de uma avaliação das autorizações para procedimentos de internação hospitalar $(\mathrm{AlH})$. Por exemplo, as laqueaduras registradas nesse sistema passaram de 293 em 1998, para 15.370 em 2001 e, para 38.276, em 2004. Já as vasectomias passaram de 324 em 1999, para 3.124 em 2001. Em 2004, o número foi de 14.021(BERQUÓ e CAVENAGHI, 2003; COSTA e col., 2006).

Apesar do crescente registro de esterilizações observadas, no estudo 
conduzido por OSIS e col.(2006) sobre atenção ao planejamento familiar no Brasil, em quatro capitais brasileiras, os autores constataram que de um modo geral, conforme o entendimento dos gestores de saúde havia uma demanda reprimida pela esterilização cirúrgica, acumulada desde a entrada em vigor da regulamentação da lei 9263.

Em estudo mais recente de OSIS e col.(2009), sobre o atendimento pela esterilização cirúrgica na Região Metropolitana de Campinas, na percepção de gestores e profissionais dos serviços públicos de saúde, ainda persiste uma demanda reprimida, com tempo médio de espera de 18 a 24 meses para laqueadura e, de 6 a 8 meses, para vasectomia.

Diferente constatação foi observada por VIEIRA e SOUZA (2009), em estudo sobre o acesso à esterilização cirúrgica pelo Sistema Único de Saúde na cidade de Ribeirão Preto (SP),quando constataram que poucos indivíduos não tiveram acesso à esterilização cirúrgica - menos que $15 \%$ do total de 230 entrevistados - sobretudo por terem adiado o procedimento e, uma menor parcela por obstáculo institucional.

\subsection{1 - A esterilização cirúrgica em homens e mulheres no contexto da contracepção.}

A esterilização cirúrgica feminina é método contraceptivo muito utilizado no mundo, cerca de 200 milhões de mulheres com união estável em idade reprodutiva foram submetidas a este procedimento em 2003 (UNITED NATIONS POPULATION DIVISION, 2005).

Um estudo da Organização Mundial de Saúde (WHO) sobre a prevalência do uso de método contraceptivo de 2005, em diferentes países, apontou, a partir de dados de 1999, que entre as mulheres em idade reprodutiva com vida conjugal, na faixa etária de 15 a 49 anos, a prevalência mundial da esterilização cirúrgica feminina e masculina é de, respectivamente, $20,5 \%$ e $3,4 \%$. Entretanto, em regiões pouco desenvolvidas, esta prevalência se eleva para $22,3 \%$ e $3,0 \%$, 
respectivamente. Revelou, ainda, que em regiões desenvolvidas esta prevalência é de $9,3 \%$ e $5,3 \%$. No Brasil, conforme o mesmo estudo da OMS, que utiliza dados relativos a 1996, e não de 1999, retirados do estudo da Pesquisa Nacional sobre Demografia e Saúde (PNDS 1996), a prevalência era de 40,1\% e 2,6\% respectivamente para a esterilização feminina e a masculina (UNITED NATIONS POPULATION DIVISION, 2005).

Em relação ao uso de pílulas anticoncepcionais, o mesmo estudo, com dados de 1999 revelou que a prevalência no mundo era de $7,5 \%$, sendo nos países desenvolvidos, de 15,9\% e, nos países menos desenvolvidos de 6,2\%. Portanto, a esterilização cirúrgica é o método contraceptivo mais prevalente em todo o mundo, sendo que nos países desenvolvidos ocorre um predomínio do uso da pílula em relação à laqueadura tubária, enquanto que nos países menos desenvolvidos prevalece a esterilização tubária (UNITEDNATIONS POPULATION DIVISION, 2005).

Semelhante cenário contraceptivo é observado por Elza Berquó, em nosso país, quando relata a partir dos dados da Pesquisa Nacional por Amostra de Domicílios de 1986, que 70\% das mulheres casadas ou unidas com idade entre 15 e 54 anos usavam métodos contraceptivos, sendo o mais prevalente a esterilização feminina $(44,4 \%)$, seguida das pílulas (41\%), que representavam $85 \%$ das usuárias. A autora aponta, igualmente, para as significativas variações regionais, sendo a laqueadura mais prevalente no Nordeste e no Estado de Goiás, do que em outras regiões do Brasil, o que significa dizer que falar em contracepção naquele contexto significava, à época, falar de pílula ou laqueadura como padrão de método contraceptivo (BERQUÓ, 1993).

Em estudo conduzido por Dias-da-Costa e colaboradores, na cidade de Pelotas no Rio Grande do Sul no período de 1992 a 1999, os autores observaram que entre 766 mulheres pesquisadas, com idade entre 20 e 49 anos, 64,6\% utilizavam algum método contraceptivo sendo que 55,4\% utilizavam contraceptivos orais, 22,2\% ligadura tubárias (DIAS-da-COSTA e col., 2002).

Dados da Pesquisa Nacional sobre Demografia e Saúde (PNDS), de 1996, 
apontavam que $76 \%$ das mulheres brasileiras em união, com idade entre 15 a 44 anos, eram usuárias de algum método contraceptivo, com uma prevalência de uso de $40,1 \%$ para esterilização feminina, 2,8\% para a vasectomia, e 20\% para a pílula. Esta situação mudou em 2006, conforme publicação do PNDS (PNDS, MS, 2009), que demonstra uma relativa melhora, ao identificar que $80,6 \%$ das mulheres unidas, com idade entre 15 a 44 anos; utilizavam algum método para regular sua fecundidade. Dessas, 29,1\% estavam esterilizadas, tinham 5,1\% dos companheiros submetidos à vasectomia e 27,4\% utilizavam pílulas (MINISTÉRIO DA SAÚDE, 2009).

Ao comparar os dados da Pesquisa Nacional sobre Demografia e Saúde (PNDS) de 2006, com os da PNDS de 1996, podemos observar que houve aumento da prevalência do uso de pílulas anticoncepcionais, o que aponta para uma redução significativa da esterilização feminina e aumento da utilização de outros métodos, especialmente da participação masculina, por meio da vasectomia e do preservativo. Apesar do aumento da utilização de pílulas anticoncepcionais, persiste a alta prevalência da esterilização cirúrgica em nosso meio, mantendo a tendência, na atualidade, de serem ambos os métodos contraceptivos mais prevalentes (MINISTÉRIO DA SAÚDE, 2009).

\subsection{2 - A esterilização cirúrgica precoce e implicações para a saúde pública.}

A esterilização cirúrgica precoce em mulheres tem sido objeto de alguns estudos quanto ao possível desejo de novas gestações após ligadura tubária. Em uma revisão sistemática conduzida por CURTIS e col. (2006), sobre arrependimento após esterilização cirúrgica feminina, constatou-se que mulheres submetidas a este procedimento antes dos 30 anos estavam duas vezes mais vulneráveis a chances de arrependimento, com uma probabilidade 3,5 a 18vezes de requererem informações sobre reversibilidade. $E$, apresentaram uma chance oito vezes maior de manifestarem interesse em submeter-se a fertilização "in 
vitro", em relação às mulheres acima de 30 anos. Concluíram, os autores, haver uma relação inversa entre arrependimento e idade da realização da esterilização cirúrgica (CURTIS e col., 2006).

Em nosso país, CUNHA e col.(2007), em estudo envolvendo 96 pacientes, no período de 1996 a 2004, sobre fatores associados ao desejo de nova gestação em mulheres após ligadura tubária, constataram que a média da idade, na época da ligadura foi de 25 anos, sendo que $55,1 \%$ tinham menos de 25 anos, 46,9\% tinham três ou mais filhos e dez tinham apenas um filho. Os motivos mais comuns para a indicação da laqueadura tubária foram: desejo de contracepção (48\%), problemas financeiros $(25,5 \%)$ e problemas conjugais (15,3\%). As principais razões para tentativa de reversão, visando nova gravidez foram: novo matrimônio ou novo parceiro $(80,6 \%)$, ter um novo filho com o mesmo parceiro $(8,2 \%)$, e morte de um filho $(6,1 \%)$. O tempo de arrependimento informado pela maioria das mulheres foi de dois a quatro anos e, a procura pela reversão, no intervalo de seis a dez anos. Para $83,6 \%$ das mulheres faltou, no momento da decisão, informação a respeito da própria laqueadura e das dificuldades para a reversão. Concluíram esses autores que a laqueadura tubária em mulheres jovens, vulneráveis e não informadas a respeito do caráter definitivo do método, pode aumentar a demanda em serviços de reprodução assistida e comprometer o futuro reprodutivo, uma vez que apenas a minoria dessas mulheres alcança o objetivo desejado, ou seja, uma nova gravidez.

O arrependimento após esterilização é uma relevante questão médica, porque, na maioria dos casos, a escolha da laqueadura é eletiva, e não se pode garantir o retorno à fertilidade. Como se sabe, existem alternativas contraceptivas tão eficazes e reversíveis do que a esterilização. Segundo VIEIRA (2007), o arrependimento já foi estimado entre 11 e $15 \%$ das mulheres brasileiras esterilizadas. Cabe ressaltar que existe uma dificuldade de estimar com precisão o arrependimento, o que levam autores a inovarem em metodologias como MarcilGratton, por exemplo, que usou uma escala de sentimentos de arrependimento para classificar as mulheres em alguns grupos: 
1. mulheres que nunca sentiram arrependimento.

2. mulheres que tentariam ter outro filho se não estivessem esterilizadas

3. mulheres que conversaram com o médico sobre a reversão da esterilização cirúrgica

4. mulheres que solicitam a reversão da laqueadura para seus médicos

Para VIEIRA (2007), alguns fatores como idade jovem, falta de estabilidade no relacionamento conjugal e morte de filho, são apontados na maioria dos estudos, em diferentes países, como predisponentes ao arrependimento. No Brasil, além de ter motivos diferentes para satisfação com o número de filhos, destaca-se a idade jovem ao ter o primeiro filho como fator para o arrependimento, visto que tal fato predispõe à laqueadura em mulher jovem. VIEIRA (2007) observou também que o pagamento, prática comum antes da regulamentação da lei, constituiu em obstáculo ao próprio arrependimento.

\section{2 - A clandestinidade como cenário da esterilização cirúrgica antes da regulamentação da lei.}

Sabe-se que a prática da esterilização no Brasil, por muitos anos, aconteceu em um cenário de clandestinidade já que, ao menos teoricamente, esta era interpretada como ofensa criminal, com base no Código Penal de 1940, Artigo 29. Parágrafo 2 III, e, segundo o Código de Ética Médica, a realização de esterilização cirúrgica foi proibida até 1988, salvo em algumas situações específicas (CARVALHO e col., 2007). Esse contexto de ilegalidade contribuiu para que se verificassem várias distorções na prática da esterilização como, por exemplo, no caso da laqueadura, a realização conforme observado anteriormente, de cesariana apenas para encobrir a cobrança adicional e a sua realização, em mulheres muito jovens e com poucos filhos, suscetível a maior risco de arrependimento (BERQUÓ e CAVENAGHI, 2004; VIEIRA, 1998).

BERQUÓ (1993) relata enfaticamente a significativa associação de parto cirúrgico e esterilização afetando a morbimortalidade materna, as condições de 
risco do recém-nascido, além do aumento dos custos hospitalares, constituindo essas associações, em sério problema de Saúde Pública. Afirma que, em 1986, $75 \%$ das esterilizações foram feitas no momento do último parto, ou seja, uma cesárea. Esta verdadeira cultura da esterilização no país era garantida pela cumplicidade entre as mulheres e os profissionais de saúde. Para as mulheres que não queriam ter mais filhos, por razões as mais variadas, e, não dispondo de recursos para comprar a pílula ou por não se sentirem bem com ela, só lhes restava a alternativa da laqueadura. Como a esterilização era proibida pelo Código Penal e pelo Código de Ética Médica, os profissionais de saúde realizavam a laqueadura durante uma cesárea. Neste caso, o custo hospitalar do paciente e os honorários dos médicos estavam cobertos pelo Instituto Nacional da Previdência Social (INAMPS) e o custo adicional da esterilização era pago "por fora", pela gestante.

Segundo BERQUÓ (1993), naquela ocasião, 55\% das mulheres esterilizadas declararam ter feito pagamento em dinheiro pela cirurgia; os arranjos com os profissionais de saúde ocorriam em $87 \%$ das vezes durante o pré-natal, $10 \%$ antes do parto e $11 \%$ durante o trabalho de parto. Além de $32 \%$ das mulheres referirem que engravidaram para serem esterilizadas durante 0 parto, provavelmente por uma cesárea.

Constata também a autora que as mulheres no Brasil, principalmente aquelas de setores populares e que eram a maioria, viviam um dilema, ou seja, contar com a pílula como um método reversível comprada nas farmácias sem receituário médico e não dispor de aborto legal para eventuais falhas ou encontrarem, na laqueadura, uma solução contra o desamparo em que essas vivenciavam a saúde reprodutiva. Esse fato originou a publicação do seu artigo; Brasil, um caso exemplar - anticoncepção e partos cirúrgicos - à espera de uma ação exemplar; que foi apresentado na Conferência Mundial sobre População e Desenvolvimento, em 1994, na cidade do Cairo (BERQUÓ, 1993).

Foi somente em 1997 que o Ministério da Saúde estabeleceu as normas para a realização da esterilização cirúrgica como método anticoncepcional no 
Sistema Único de Saúde (SUS), através da Portaria nº 144/97, que regulamentou os parágrafos correspondentes à esterilização na Lei no 9.263, sancionada em 12 de janeiro de 1996. Desde então, os serviços públicos de saúde devem oferecer, entre outros métodos anticoncepcionais, a laqueadura tubária e a vasectomia, mediante o cumprimento de alguns requisitos. A pessoa solicitante deve ter capacidade civil plena, ser maior de 25 anos ou ter, pelo menos, dois filhos vivos. A cirurgia só pode ser realizada depois de decorridos, no mínimo, sessenta dias a partir da manifestação do desejo de fazê-la. Durante esse período, a pessoa que solicita a esterilização deverá participar de sessões de orientação, incluindo aconselhamento por equipe multidisciplinar, visando a desencorajar a esterilização precoce. Ainda segundo a referida lei, a esterilização não pode ser realizada no momento de um parto ou aborto, exceto quando houver necessidade comprovada, em virtude de cesarianas sucessivas anteriores.

Alguns obstáculos ao cumprimento da lei são observados, como por exemplo, a falta de insumos adequados para oferecimento de todos os métodos contraceptivos, clientelismo eleitoral, além da resistência de profissionais de saúde em aceitarem os critérios estabelecidos pela lei, especialmente no que se refere à idade mínima, considerada muito jovem. O principal argumento de muitos profissionais, segundo Carvalho e col.(2007), refere-se à maior possibilidade de arrependimento das pessoas mais jovens.

\section{3 - A contracepção no contexto dos Direitos Sexuais e Direitos Reprodutivos como uma conquista.}

A oferta de métodos contraceptivos em programas de saúde tem como base os direitos reprodutivos. "A noção de direito reprodutivo como direito humano desenvolveu-se principalmente a partir da última metade do século $X X$, relacionado às mudanças no papel das mulheres e seu valor na sociedade e às mudanças do seu comportamento diante do desenvolvimento de novas tecnologias médicas" (VIEIRA, 2007). 
A noção dos direitos reprodutivos expandiu-se no movimento feminista mundial na metade dos anos 1980, depois do Congresso Internacional de Saúde e Direitos Reprodutivos, ocorrido em Amsterdã em 1984. A pauta do encontro privilegiou as denúncias às políticas demográficas em curso nos países do sul, ao mesmo tempo em que assinalava questões emergentes, tais como o incremento das técnicas de concepção nos países do norte (SCAVONE, 2004).

$\mathrm{Na}$ origem deste conceito estava presente uma das ideias fundadoras do feminismo contemporâneo: o direito ao próprio corpo, baseado nos princípios de autonomia e liberdade, expresso na máxima. "Nosso Corpo nos pertence". Os direitos reprodutivos que nasceram da luta do Movimento Feminista Internacional, conforme acima sinalizado, notadamente no direito à livre escolha da maternidade, ao aborto, à contracepção - e podem ser considerados, do ponto de vista de direitos humanos, uma ampliação deles. Porém, do ponto de vista feminista, a noção dos direitos reprodutivos tinha um significado político social mais abrangente, pois ela remetia ao questionamento das relações de gênero tanto no interior da família, como na orientação das políticas de planejamento familiar em vigor. Não se tratava só de politizar as questões privadas e trazê-las para o debate público, sobretudo, mediante esta luta, alcançar a equidade de gênero (SCAVONE, 2004).

A lei 9263(1996) emerge no Brasil, no contexto da reivindicação dos Direitos Sexuais e Reprodutivos pelo feminismo e outros movimentos sociais, como os de gays e lésbicas (ÁVILA, 2003); reivindicação essa que teve origem na Declaração dos Direitos Humanos, em 1948, sendo referendadas como Direitos Humanos inalienáveis a partir da Conferência Mundial sobre população e desenvolvimento (Cairo 1994) e na Conferência Mundial sobre a Mulher (Beijing 1995). Na Conferência de Cairo, esses direitos baseiam-se no reconhecimento do direito básico de todas as pessoas de decidir livremente sobre o número de filhos e espaçamento dos nascimentos, assim como dispor de informações e recursos para exercerem esses direitos e alcançar o nível mais alto possível de saúde sexual e reprodutiva. Esses direitos são ampliados na Conferência Mundial sobre 
a Mulher em Beijing (1995) e se traduzem no reconhecimento do livre exercício da sexualidade e na autonomia das decisões individuais e dos casais, no que diz respeito a vida sexual e reprodutiva e contemplam o direito a uma sexualidade saudável sem o risco de uma gravidez indesejada (ORGANIZAÇÃO DAS NAÇÕES UNIDAS, 1996).

A Política Nacional de Atenção Integral à Saúde da Mulher (PNAISM) foi elaborada em 2003, quando a equipe técnica de saúde da mulher realizou um diagnóstico epidemiológico da situação da saúde da mulher no Brasil e definiu a importância de contar com um total de dezesseis diretrizes, que orientaram as políticas de Saúde da Mulher estabelecendo parcerias com diferentes departamentos, coordenações e comissões do Ministério da Saúde. Incorporava também as contribuições do movimento de mulheres, de mulheres negras e de trabalhadoras rurais, das sociedades científicas, pesquisadores e estudiosos da área, organizações não governamentais, gestores do SUS e agências de cooperação internacional (MINISTÉRIO DA SAÚDE, 2008).

Em março de 2005, atendendo também às reivindicações da sociedade civil, o Ministério da Saúde lançou a Política Nacional de Direitos Sexuais e Direitos Reprodutivos. Essa Política representa um grande avanço no sentido em que firma os compromissos assumidos pelo Governo brasileiro nos acordos assinados na Conferência Internacional sobre População e Desenvolvimento, realizada no Cairo (1994) e na IV Conferência Mundial sobre a Mulher, realizada em Beijing (1995). (MINISTÉRIO DA SAÚDE, 2007).

A política do planejamento reprodutivo, que corresponde ao anteriormente denominado programa de planejamento familiar, vem sendo desenvolvida pelo Ministério da Saúde em parceria com os estados, municípios e sociedade civil organizada, no âmbito da atenção integral à saúde da mulher, do homem e de adolescentes. Ela está de acordo com os preceitos legais estabelecidos na Constituição Federal de 1988 e na Lei Federal n. 9.263, de 12 de janeiro de 1996, que regulamenta o planejamento reprodutivo (MINISTÉRIO DA SAÚDE, 2007).

$O$ grande desafio em relação ao planejamento reprodutivo ainda reside no 
fato de haver um suprimento de insumos em quantidades insuficientes para atender a demanda, além de haver uma descontinuidade de fornecimento dos mesmos em nível dos serviços, por dificuldades relativas à sua distribuição, fatos esses constatados por OSIS e col. (2006), no período de abril e maio de 2004, quando pesquisou sobre a disponibilidade de métodos contraceptivos em quatro capitais de Estado do país, quais sejam Curitiba, Belém, Salvador e Goiânia. Isso apesar do fato de que no ano de 2006, conforme dados do Ministério da Saúde (2007), ter ocorrido a distribuição de 18 milhões de cartelas de pílulas combinadas de baixa dosagem, 1,2 milhões de pílulas somente de progesterona, 207 mil cartelas de anticoncepcional de emergência, 542 mil ampolas de injetável mensal, 250 mil de ampolas do injetável trimestral e 176 mil DIU (Dispositivo Intra-Uterino) atendendo a 5.242 municípios (MINISTÉRIO DA SAÚDE, 2007).

A Área Técnica de Saúde da Mulher, reconhecendo a dificuldade de acesso para homens e mulheres que desejam realizar a esterilização cirúrgica voluntária (laqueadura tubária e vasectomia) no SUS, estabeleceu a meta de aumentar em 50\%, no período de 2004 a 2007, em todos os Estados, o número de serviços credenciados para a realização desses procedimentos, essa decisão que veio em conformidade com a Lei $n . .9 .263$, já mencionada regulamenta o planejamento reprodutivo. Esse aumento pode ser observado quando se constata que em 2003, existiam aproximadamente 431 instituições habilitadas no SUS para esses procedimentos alcançando, em setembro de 2006, mais de 673 instituições habilitadas (MINISTÉRIO DA SAÚDE, 2007).

Em 2007, o governo brasileiro lança o II Plano Nacional de Políticas para as Mulheres, elaborado a partir da construção participativa, envolvendo diretamente cerca de 200 mil mulheres brasileiras, em conferências municipais e estaduais preparatórias para a II Conferência Nacional de Políticas para as Mulheres (MINISTÉRIO DA SAÚDE, 2008). Nessa Conferência foram apresentados os seguintes diagnósticos em relação à Saúde das mulheres, direitos sexuais e direitos reprodutivos:

- o acesso à anticoncepção é direito garantido constitucionalmente e não é 
amplamente atendido.

- existe um predomínio de uso da laqueadura tubária e da pílula.

- a baixa prevalência de outros métodos indica o limitado acesso às mulheres a outros métodos disponíveis.

- existem problemas na produção, controle de qualidade, aquisição, logística de distribuição de insumos e manutenção da continuidade da oferta de métodos anticoncepcionais.

- o resultado é uma atenção ainda precária e excludente, com maior prejuízo para as mulheres oriundas das camadas mais pobres e das áreas rurais.

- possivelmente esta situação contribui para a ocorrência de abortamentos em condições inseguras e para o aumento do risco de morte por esta causa.

Com base nestas análises o referido plano estabelece como metas, para o período 2008-2011, garantir a oferta de métodos anticoncepcionais reversíveis para $100 \%$ da população feminina usuária do SUS e disponibilizar métodos anticoncepcionais em 100\% dos serviços públicos de saúde (SECRETARIA ESPECIAL DE POLÍTICA PARA MULHERES, 2008).

Em 2008 o Ministério da Saúde ampliou a aquisição e distribuição dos métodos contraceptivos para os municípios, passando também a disponibilizar anticoncepcionais em farmácias populares, a baixo custo, com o objetivo de atender as metas do referido plano. Inclui ainda como metas a implantação até 2011, de um serviço público para reprodução assistida em cada região do país, vinculada aos hospitais universitários e ampliação de cadastro de serviços para a realização de vasectomia e laqueadura (UNPFA, 2008). 


\section{4 - A Regulamentação da Lei 9263/96 como reconhecimento dos}

\section{Direitos Sexuais e Direitos Reprodutivos no Brasil.}

No século XX, no Brasil, a atenção à saúde da mulher se restringia, basicamente, a programas de pré-natal, voltada à exaltação da maternidade sendo o discurso dominante a institucionalização do parto que visava essencialmente o bem estar do recém-nascido e a redução da mortalidade materna. Nessa atenção pode se observar uma preocupação demográfica e social relacionada à criança e não necessariamente à proteção da mulher. Até a década de 1970, o atendimento à saúde da mulher centralizou-se na esfera do ciclo grávido-puerperal. (MINISTÉRIO DA SAÚDE, 2001).

A ampliação da oferta de serviços de atenção à saúde da mulher, a partir dos anos 1960, ainda não tinha por objetivo o atendimento abrangente às necessidades de saúde. Foi o crescimento populacional, ocorrido nos países desenvolvidos, o motivador de investimentos internacionais nas políticas de contracepção, dirigidos às populações mais pobres. Nas décadas de 1960/1970 são

implantados programas verticais de planejamento familiar no Brasil, ao mesmo tempo em que foi autorizada a atuação da Sociedade Civil de Bem-Estar Familiar (BEMFAM), dentre outras, na área, com o mesmo objetivo de distribuir métodos contraceptivos e treinar profissionais em planejamento familiar, sendo essas responsáveis pela consolidação da ideologia contraceptiva intervencionista notadamente no meio médico. O governo, contraditoriamente, neste período, pregava os princípios pró-natalistas, que visavam ocupar os espaços vazios de nosso território (MINISTÉRIO DA SAÚDE, 2001).

ALVARENGA e SCHOR (1998) identificaram controvérsias, em nível do Estado, ao analisar questões de contracepção feminina e como eram problematizadas por setores da sociedade e do governo, através dos discursos desses divulgados na mídia. Foi possível depreender que o Estado, até meados da década de 1990, tinha duas propostas diferentes, uma de controle de natalidade, com seus pressupostos demográficos e, outra, de planejamento 
familiar, na perspectiva de políticas de desenvolvimento social e de saúde.

As autoras identificaram três períodos distintos na conjuntura brasileira. De 1965 a 1974, em que o Brasil vivia sob a ditadura militar, defendia-se uma política pró-natalista, com uma concepção desenvolvimentista de ocupação de espaços, ao mesmo tempo em que era bastante permissiva a atuação de clínicas privadas de planejamento familiar. O período de 1974 a 1984 se caracteriza como fase de transição, delimitada por duas grandes Conferências Mundiais de População, a de Bucarest (1974) e a da cidade do México (1984). Essas atuam como marco pelo tipo de posição diferenciada assumida pelo Brasil buscando uma posição de afirmação ditada pela conjuntura econômica, política e social da sociedade brasileira naquele momento.

Para essas autoras, o terceiro período, de 1984 a 1993, caracteriza-se por uma indefinição de uma política para o setor centrada na polêmica planejamento familiar versus controle da natalidade presente nos discursos de representantes de diferentes ministérios. Apontam para o fato de, na época, a concepção e a contracepção serem integradas à saúde reprodutiva no Programa de Assistência Integral à Saúde da Mulher (PAISM) como bandeira do Ministério da Saúde.

A redemocratização ocorrida no Brasil, na década de 1980, representou um marco importante no que se refere às reivindicações e conquistas das mulheres quanto ao direito à saúde reprodutiva. O Programa de Assistência Integral à Saúde da Mulher (PAISM), lançado em 1983 e regulamentado em 1986, resultou do esforço de profissionais da saúde, do movimento de mulheres e dos técnicos do próprio Ministério da Saúde, no sentido de preconizar ações que ampliavam significativamente o atendimento à saúde da mulher (OSIS, 1998; MARCOLINO, 2004).

O Programa de Assistência Integral à Saúde da Mulher (PAISM) foi anunciado como uma nova abordagem da saúde da mulher, baseado no conceito de "atenção integral à saúde das mulheres". Representava um avanço na medida em que se tratava de um programa que contemplava a regulação da fecundidade inserindo a saúde da mulher em um contexto mais amplo e não restrito apenas no 
campo da saúde materno-infantil (OSIS, 1998).

Nesse contexto, as diretrizes do programa visavam a uma assistência integral, clínico-ginecológica e educativa, voltada ao aperfeiçoamento do controle pré-natal, do parto e puerpério, à abordagem dos problemas desde a adolescência até a terceira idade, ao controle das doenças sexualmente transmitidas, do câncer do colo e das mamas e à assistência para concepção e contracepção (OSIS, 1998).

Segundo ALVARENGA e SCHOR (1998), no período pós-1993, as discussões de planejamento familiar versus controle de natalidade dão lugar às questões da regulação da fecundidade, enfocando problemas específicos como a descriminalização e a legalização do aborto e a regulamentação, pelo Estado, da esterilização feminina e masculina.

Por influência das diretrizes de ação da Conferência de População e desenvolvimento realizada no Cairo, em 1994, e de Beijing, em 1995, ocorre um deslocamento da discussão para a saúde reprodutiva e a sexualidade como direitos do cidadão. O conceito de Saúde Reprodutiva, apontado para a integralidade dos fenômenos reprodutivos, ganha expressão crescente no campo da Saúde Pública.

Após este período, com o reconhecimento do direito ao planejamento familiar na Constituição Federal, promulgada em 1988, foi aprovada em 1996 a Lei 9263/96, que regulamenta a esterilização cirúrgica no Brasil considerada um avanço do ponto de vista de Direitos Reprodutivos naquela ocasião. Com esta lei pretendiase garantir aos cidadãos o exercício dos direitos reprodutivos $e$, mais especificamente, garantir o direito ao controle da fecundidade de forma segura, com o apoio do Estado por meio do Sistema Único de Saúde (ALVARENGA e SCHOR, 1998). 


\section{5 - Sobre a regulamentação da Lei 9263/96 e controvérsias do texto oficial: divergências na interpretação e desafios na aplicação da lei 9263/96 como relevante tema de pesquisa.}

BERQUÓ e CAVENAGHI (2003), em estudo sobre o cumprimento da lei 9263/96 pelo SUS e os direitos reprodutivos, realizaram entrevistas com os diretores de hospitais e de ambulatórios, no qual foram envolvidas seis capitais do país. Utilizando-se de entrevistas sobre a adequação ou não dos critérios exigidos pela Lei 9.263 para a realização da esterilização voluntária, as autoras constataram que o critério da idade mínima foi considerado o mais inadequado, porque precoce, por $71 \%$ dos entrevistados, seguido do número mínimo de dois filhos nascidos vivos (46\%). Outro aspecto mencionado como inadequados foi o da exclusão da esterilização no momento do parto / aborto e puerpério (39\%) e, finalmente, a carência de 60 dias (29\%) entre a aprovação da esterilização pela equipe e sua execução, que foi considerada como muito longa. A objeção de 25 anos como idade mínima para a realização da esterilização foi também endossada por gestores estaduais e municipais de saúde.

Tais constatações, que podemos considerar como indicadores da existência de controvérsias na interpretação e execução da lei podem ser observados em outros estudos. Um exemplo de complexidade na interpretação da lei é o da entrevista de Cristião Fernando Rosas, na ocasião, Conselheiro do Conselho Regional de Medicina do Estado de São Paulo, em matéria de MARISCAL (2001), em relação às questões éticas e de outras ordens, presentes na lei 9263/1996. Rosas afirma que, em termos da opção pela esterilização, as mulheres tendem a estarem vulneráveis por circunstâncias sociais, culturais e econômicas. Aponta que a legislação é extremamente aberta no seu artigo 10, em relação à autonomia e a manifestação da vontade da mulher ou homem, uma vez que, prevê a realização da esterilização com 25 anos ou pelo menos dois filhos vivos. Considera, porém, a lei paradoxalmente restritiva quando aplicada à mulher na condição de gestante, proibindo a laqueadura tubária durante os períodos do 
parto, aborto e puerpério. Aponta, igualmente, que o "espírito" da lei visa à redução da incidência de cesárea para o procedimento de laqueadura. Vale observar que são excluídos dessa proibição os casos de cesáreas de repetição pelo maior risco de futuras gestações devido às más condições uterinas. Outra exceção ocorre quando as gestantes, em estados avançados de doenças crônicas, tais como diabetes mellitus, cardiopatia e hipertensão arterial, têm o risco de morte materna, ou fetal, aumentado em futuras gestações. Nessas circunstâncias, a indicação deve ser assinada por dois médicos, com o consentimento expresso da paciente. Assim, somente mediante indicação médica deve-se proceder à esterilização cirúrgica durante os períodos do parto ou aborto até o $42^{\circ}$ dia do período puerperal.

Divergências em relação à interpretação da lei encontram-se, também, presentes na literatura, principalmente em relação à idade mínima. De acordo com alguns estudiosos do assunto, como VIEIRA e col.(2005), BARBOSA e col. (2009), MARCOLINO (2004), BARBOSA e KNAUTH (2003), o critério da idade mínima, segundo o texto da lei 9263/96, é de 25 anos para realização da esterilização cirúrgica. Para outros autores, como ROSAS (2001), HENTZ (2004) e OSIS e col.(2009), a interpretação difere na medida em que entendem que o referido artigo da lei 9263/96 prescreve 25 anos ou pelos menos dois filhos vivos, portanto, sem especificação de idade mínima e sem combinação dos dois critérios.

Rosas na referida entrevista a Mariscal, sinaliza aspectos que consideramos importante tendo em vista a aplicação da lei. Considera que a legislação em análise representa um avanço em relação aos direitos reprodutivos e que o artigo 10 da lei 9263/96 não deve ser interpretado isoladamente, mas como parte integrante de um conjunto de ações de atenção à mulher, ao homem e ao casal, dentro de uma visão de atendimento global e integral à saúde (MARISCAL, 2001).

A despeito de críticas ao texto da lei, em alguns aspectos, vale mencionar que para autores como BERQUÓ e CAVENAGHI (2003), a aprovação da lei 9263,em 1996, teve o inegável mérito de garantir o amplo acesso à esterilização 
cirúrgica no Brasil, até então praticado em cenário de clandestinidade, conforme já observado, e também de coibir a indicação de parto cesariana para fins exclusivos de esterilização cirúrgica.

Diante de tais constatações, presentes na literatura especializada, consideramos que algumas questões se apresentam como relevantes do ponto de vista investigativo na medida em que ao se observar divergências na interpretação da lei entre diversos pesquisadores do tema, presume-se que tais divergências ocorram, igualmente, entre os profissionais que aplicam alei o que significaria em termos de hipótese, considerarmos a existência de conflitos, dilemas e desafios entre os profissionais nos processos de interpretação e aplicação da lei em nível dos serviços de saúde. É nessa linha de preocupação que o presente trabalho foi desenvolvido. 


\section{3 - HIPÓTESES}

1- Questões morais, éticas e ideológicas norteiam diferentes interpretações da Lei por profissionais de saúde.

2- Os direitos sexuais e os direitos reprodutivos da mulher previstos na Lei 9263/96 não são necessariamente respeitados, uma vez que, mesmo obedecendo aos critérios e tendo a aprovação da equipe multidisciplinar, a decisão final fica centralizada no poder médico e dentre esses profissionais não há consenso na aplicação da Lei. 


\section{4 - OBJETIVOS}

1. Caracterizar os sujeitos da pesquisa do ponto de vista sócio-demográfico e profissional.

2. Identificar como profissionais de saúde conhecem a Lei 9263 e interpretam seu texto.

3. Identificar, na perspectiva dos profissionais de saúde, que artigos do texto da Lei apresentam controvérsias na sua interpretação e aplicação.

4. Interpretar como questões éticas, morais, sociais e clínicas se relaciona com as controvérsias na interpretação e aplicação da Lei e os desafios que se colocam para cumprimento da mesma como resposta aos Direitos Sexuais e Direitos Reprodutivos das mulheres. 


\section{5- PROCEDIMENTO METODOLÓGICO.}

\section{1- Natureza da pesquisa.}

Dada à natureza do problema de investigação, a presente pesquisa se circunscreveu a uma abordagem do tipo qualitativa, uma vez que nos propomos a apreender as experiências e vivências de profissionais de saúde em relação à aplicação e interpretação da lei 9263/96 e que questões éticas, religiosas e ideológicas norteiam decisões e práticas desses profissionais.

\section{2- Sujeitos da pesquisa}

O serviço de planejamento familiar previsto na lei 9263/96 deve contemplar uma equipe multidisciplinar. Embora os mesmos não estejam especificados em nível das práticas dos serviços se observa habitualmente enfermeiras, médicos, assistentes sociais e psicólogos. Quando o casal apresenta desejo de contracepção para planejar sua família é oferecido ao mesmo, ou ao homem ou à mulher, orientação acerca dos métodos contraceptivos disponíveis e seus efeitos adversos. Tal orientação é em geral realizada por um profissional de enfermagem e, após a mesma, na medida em que a mulher ou o homem opta por um método de esterilização cirúrgica definitiva, como a vasectomia ou laqueadura tubária, é elaborada, pelo serviço um processo para aprovação e liberação do procedimento, que consta usualmente de um relatório da assistente social, o parecer favorável de dois médicos e, quando houver nesta equipe, também o relatório do psicólogo.

Ocorrendo a aprovação, que é de competência exclusiva de dois médicos, apresentando-se, assim, os pareceres de assistente social e psicólogo, como subsídios para tal decisão, a mulher, ou o homem, é encaminhado para o médico, tendo em vista a execução do procedimento. Vale registrar que tal procedimento pode ser solicitado pelo casal fora do ciclo gestacional ou durante uma dada gestação. Neste último caso, o procedimento é realizado por equipe médica de plantão, que em algumas situações podem discordar da execução devido a 
controvérsias na interpretação do texto da lei.

A elaboração do processo para aprovação da esterilização pode ser feita por equipes de planejamento familiar tanto em âmbito das Unidades Básicas de Saúde (UBS), como em âmbito hospitalar.

Nesse sentido, no atual contexto, o papel da equipe multidisciplinar é subsidiar a decisão médica. Cabem, assim, ações específicas para cada um dos membros da equipe como, por exemplo: ao profissional de enfermagem cabe a responsabilidade pela orientação das mulheres em relação aos métodos contraceptivos, inclusive quanto aos definitivos e teoricamente irreversíveis, baseados no texto da lei 9263, embora não execute o procedimento. Ao profissional do serviço social cabe elaborar o relatório para auxiliar na tomada de decisão dos profissionais médicos; e também, ao Psicólogo, cabe tarefa similar a do assistente social. Aos médicos cabe a responsabilidade pela aprovação e execução do procedimento.

Considerando tais características da equipe e atividades que permeiam a esterilização, esta pesquisa se propôs a trabalhar com quatro grupos de profissionais, considerados sujeitos da pesquisa:

a) Grupo 1-15 médicos.

b) Grupo 2- 04 enfermeiras

c) Grupo 3- 04 assistentes sociais

d) Grupo 4-04 psicólogas

No Grupo 1:

- 5 médicos plantonistas do Hospital e Maternidade Leonor Mendes de Barros, pois são os profissionais que executam o procedimento quando a mulher se encontra gestante.

- 5 médicos que executam ou participam da solicitação e aprovação dos processos para esterilização cirúrgica no Hospital e Maternidade Leonor Mendes de Barros.

- 5 médicos das Unidades Básicas de Saúde (UBS), que participam da solicitação e do processo de aprovação do procedimento. 
No Grupo 2:

- 2 enfermeiras que atuam no processo de orientação do planejamento familiar do Hospital e Maternidade Leonor Mendes de Barros.

- 2 enfermeiras da Unidade Básica de Saúde (UBS), que participam do processo de aprovação do procedimento.

No Grupo 3:

- 2 assistentes sociais do Hospital e Maternidade Leonor Mendes de Barros.

- 2 assistentes sociais das Unidades Básicas de Saúde (UBS), onde participam do processo de aprovação do procedimento.

No Grupo 4:

- 4 psicólogos que trabalhem em serviços hospitalares e UBS que participam da equipe multidisciplinar e do encaminhamento e orientação para a realização da esterilização cirúrgica.

O quadro abaixo representa a síntese do perfil profissional dos entrevistados, com a descrição por categoria profissional, idade, sexo, estado civil, tempo de atividade profissional (Tempo de ativ. prof.), tempo de atividade em planejamento familiar ( Tempo de ativ. P. F.) e local de trabalho, divididos em Unidade Básica de Saúde(UBS) e Hospital, já nos caso dos médicos subdivididos em UBS, do Hospital e plantonistas do Hospital. 
Quadro 1 - Síntese do Perfil Profissional dos entrevistados.

\begin{tabular}{|c|c|c|c|c|c|c|}
\hline $\begin{array}{l}\text { Categoria } \\
\text { profissional }\end{array}$ & Idade & Sexo & \begin{tabular}{|l|}
$\begin{array}{l}\text { Estado } \\
\text { civil }\end{array}$ \\
\end{tabular} & $\begin{array}{l}\text { Tempo } \\
\text { de } \\
\text { ativ.prof. }\end{array}$ & $\begin{array}{l}\text { Tempo de } \\
\text { ativ. P. F. }\end{array}$ & $\begin{array}{l}\text { Local de } \\
\text { trabalho }\end{array}$ \\
\hline \multicolumn{7}{|l|}{ MÉDICOS } \\
\hline Anfitrite & 39 & $\mathrm{~F}$ & casada & 14 & 12 & Ubs \\
\hline Deméter & 35 & $\mathrm{~F}$ & casada & 31 & 31 & Ubs \\
\hline Afrodite & 48 & $\mathrm{~F}$ & casada & 25 & 25 & Hospital \\
\hline Calíope & 38 & $\mathrm{~F}$ & casada & 15 & 15 & Hospital \\
\hline Nikê & 48 & $\mathrm{~F}$ & casada & 24 & 24 & Plantonista \\
\hline Átropos & 41 & $\mathrm{~F}$ & casada & 17 & 17 & Hospital \\
\hline Láquesis & 55 & $\mathrm{~F}$ & casada & 32 & 32 & Plantonista \\
\hline Aristeu & 54 & $M$ & casado & 31 & 31 & Ubs \\
\hline Eros & 56 & $M$ & casado & 30 & 30 & Ubs \\
\hline Ares & 46 & $M$ & casado & 20 & 20 & Ubs \\
\hline Zeus & 51 & $M$ & casado & 29 & 29 & Hospital \\
\hline Hermes & 56 & $M$ & casado & 32 & 32 & Hospital \\
\hline Apolo & 57 & $M$ & casado & 32 & 32 & Plantonista \\
\hline Dionísio & 50 & $M$ & solteiro & 24 & 24 & Plantonista \\
\hline Hefesto & 57 & $\mathrm{M}$ & casado & 32 & 32 & Plantonista \\
\hline \multicolumn{7}{|c|}{ PSICÓLOGOS } \\
\hline Eufrosina & 54 & $\mathrm{~F}$ & casada & 30 & 1 & Ubs \\
\hline Graças & 28 & $\mathrm{~F}$ & casada & 8 & 4 & Ubs \\
\hline Tália & 46 & $\mathrm{~F}$ & casada & 6 & 6 & Hospital \\
\hline Agalaia & 52 & $\mathrm{~F}$ & casada & 28 & 10 & Hospital \\
\hline \multicolumn{7}{|c|}{ ASSISTENTES SOCIAIS } \\
\hline Ártemis & 46 & $\mathrm{~F}$ & solteira & 17 & 1 & Ubs \\
\hline Atena & 50 & $\mathrm{~F}$ & casada & 29 & 5 & Ubs \\
\hline Erínias & 50 & $\mathrm{~F}$ & casada & 25 & 8 & Hospital \\
\hline Eumênides & 40 & $\mathrm{~F}$ & solteira & 8 & 8 & Hospital \\
\hline \multicolumn{7}{|c|}{ ENFERMEIROS } \\
\hline Hera & 42 & $\mathrm{~F}$ & casada & 11 & 11 & Ubs \\
\hline Íris & 46 & $\mathrm{~F}$ & solteira & 28 & 20 & Hospital \\
\hline Hebe & 46 & $\mathrm{~F}$ & solteira & 22 & 8 & Ubs \\
\hline Nêmesis & 52 & $\mathrm{~F}$ & solteira & 25 & 15 & Hospital \\
\hline
\end{tabular}




\section{3 - Trabalho de Campo.}

Para a realização das entrevistas, que tem como base a história oral, foi utilizada a técnica de depoimento. Norteadas por um roteiro temático (Anexo II), com temas considerados importantes para a investigação do problema, mas que igualmente contemplasse a abertura de espaço para a emergência de outros. Foram realizadas no período de outubro de 2010 a janeiro de 2011, incluindo profissionais do Hospital Maternidade Leonor Mendes de Barros e das Unidades Básicas de Saúde, localizados na zona leste do município de São Paulo; em sala apropriada, no local de trabalho dos diferentes profissionais entrevistados. Antes do início das entrevistas tivemos o cuidado de entregar uma cópia do texto da lei 9263 para evitar qualquer tipo de constrangimento aos profissionais durante a entrevista, pois não sabíamos previamente qual era o grau de conhecimento do texto da lei de cada profissional. Tais entrevistas foram gravadas após o consentimento por parte destes profissionais (RIGOTTO, 1998)-(Anexo III).

\section{4 - Tratamento e Interpretação das Narrativas.}

Os relatos orais obtidos foram transcritos por uma profissional e revisadas pelo pesquisador.

Para o tratamento dos dados buscamos identificar núcleos estruturadores do Discurso a partir, primeiro, de identificação de palavras-chave e expressões representativas do tema, as quais foram organizadas em categorias específicas e, a seguir, em categorias gerais. Foram estas últimas, as categorias gerais, reagrupadas em núcleos tendo em vista a estruturação dos discursos proferidos e a seguir foi realizada a interpretação das narrativas (MINAYO, 2004; SPINK, 2004).

$\mathrm{Na}$ interpretação das narrativas utilizamos a análise de discurso, tendo em vista contextualizar os sujeitos investigados e identificar de que lugar os mesmos falam, buscando captar o sentido e a ideologia contidos nos discursos destes profissionais (CAREGNATO e MUTTI,2006). 
As categorias gerais para a análise são as seguintes:

- concepção dos profissionais sobre a esterilização como método contraceptivo.

- concepção dos profissionais sobre a regulamentação da lei 9263/96.

- a esterilização cirúrgica na prática dos serviços de saúde.

- das ambiguidades e das controvérsias relativas à lei 9263/96 aos dilemas nas decisões para sua aplicação.

- sobre o aperfeiçoamento da lei 9263/96 nos discursos dos profissionais

\subsection{Aspectos Éticos.}

O projeto de pesquisa foi submetido à aprovação e o inicio do trabalho de campo só foi iniciado após a aprovação do Comitê de Ética em Pesquisa da Faculdade de Saúde Pública da Universidade de São Paulo, da Secretaria Municipal de Saúde de São Paulo e do Hospital Maternidade Leonor Mendes de Barros.

De acordo com as normas estabelecidas pela resolução 196/96 do Conselho Nacional de Saúde (Ministério da Saúde, 1996), os participantes do presente estudo receberam informações sobre o mesmo, sendo que sua participação foi voluntária. Os sujeitos, que mediante explicação dos objetivos da pesquisa, concordaram em fazer a entrevista tiveram a privacidade e o sigilo garantidos, assim como a liberdade de desistir a qualquer momento, sem qualquer prejuízo do entrevistado.

A inclusão dos profissionais de saúde foi realizada, exclusivamente, após assinatura do termo de Consentimento Livre e Esclarecido (Anexo III). 


\section{ANÁLISE DOS DISCURSOS DE PROFISSIONAIS DASAÚDE.}

\subsection{Caracterização dos sujeitos de pesquisa.}

Ártemis, assistente social, 46 anos, solteira, não têm filhos, exerce a profissão há 17 anos, trabalha em Unidade Básica de Saúde com planejamento familiar há 01 ano; é católica praticante.

Atena, assistente Social, 50 anos, casada têm 01 filho, exerce a profissão há 29 anos, trabalha em Unidade Básica de Saúde com planejamento familiar há 05 anos; é católica não praticante.

Erínias, assistente social, 50 anos, casada, têm 02 filhos, exerce a profissão há 25 anos, trabalha em Hospital com planejamento familiar há 08 anos; é evangélica não praticante.

Eumênides, assistente social, 40 anos, solteira, não têm filhos, exerce a profissão há 08 anos, trabalha em Hospital com planejamento familiar há 05 anos; é católica praticante.

Hera, enfermeira, 42 anos, casada, não têm filhos, exerce a profissão há 11 anos, trabalha em Unidade Básica de Saúde com 
planejamento familiar há 11 anos; é evangélica praticante.

Íris, enfermeira, 46 anos, solteira, não têm filhos, exerce a profissão há 28 anos, trabalha em Hospital no planejamento familiar há 20 anos; é católica praticante.

Hebe, enfermeira, 46 anos, solteira, não têm filhos, exerce a profissão há 22 anos, trabalha em Unidade Básica de Saúde com planejamento familiar há 08 anos; é espírita praticante.

Nêmesis, enfermeira, 52 anos, solteira, não têm filhos, exerce a profissão há 25 anos, trabalha em Hospital com planejamento familiar há 15 anos; é católica praticante.

Anfitrite, médica, 39 anos, casada, têm 02 filhos, exerce a profissão há 14 anos, trabalha em Unidade Básica de Saúde com planejamento familiar na solicitação e aprovação do procedimento há 08 anos, mas executa o procedimento há 12 anos; é católica não praticante.

Aristeu, médico, 54 anos, casado, têm 03 filhos, exerce a profissão há 31 anos e trabalha em Unidade Básica de Saúde na 
solicitação e aprovação da esterilização cirúrgica, mas executa o procedimento há 31 anos; é católico praticante.

Eros, médico, 56 anos, casado, têm 02 filhos, exerce a profissão há 30 anos e trabalha em Unidade Básica de Saúde na solicitação e aprovação da esterilização cirúrgica, mas executa o procedimento há 30 anos; é espírita praticante.

Ares, médico, 46 anos, casado, têm 03 filhos, exerce a profissão há 20 anos, trabalha em Unidade Básica de Saúde na solicitação e aprovação da esterilização cirúrgica e executa o procedimento há 20 anos; é católico praticante.

Deméter, médica, 55 anos, casada, têm 02 filhos, exerce a profissão há 31 anos, trabalha em Unidade Básica de Saúde com planejamento familiar na solicitação $e$ aprovação do procedimento há 30 anos, mas executa o procedimento há 31 anos; é católica não praticante.

Afrodite, médica, 48 anos, casada, têm 02 filhos, exerce a profissão há 25 anos, trabalha em Hospital no processo de solicitação e 
aprovação do procedimento, mas executa 0 procedimento há 25 anos; é católica não praticante.

Átropos, médica, 41 anos, casada, têm 02 filhos, exerce a profissão há 17 anos, trabalha em Hospital no processo de solicitação e aprovação do procedimento, mas executa o procedimento há 17 anos; é católica não praticante.

Zeus, médico, 51 anos, casado, não têm filhos, exerce a profissão há 29 anos, trabalha em hospital na solicitação e aprovação do procedimento, mas executa a esterilização há 29 anos; não é adepto a nenhuma religião.

Calíope, médica, 38 anos, casada, têm 01 filho, exerce a profissão há 15 anos, trabalha em Hospital no processo de solicitação e aprovação do procedimento, mas executa 0 procedimento há 15 anos, é espirita não praticante.

Hermes, médico, 56 anos, solteiro, não têm filhos, exerce a profissão há 32 anos, trabalha em Hospital no processo de solicitação e aprovação do procedimento, mas executa 0 procedimento há 32 anos; é espirita praticante. 
Nikê, médica, 48 anos, casada, têm 01 filho, exerce a profissão há 24 anos, trabalha em Hospital, é plantonista e executa o procedimento há 24 anos; é espírita praticante.

Apolo, médico, 57 anos, casado, não têm filhos, exerce a profissão há 32 anos, trabalha em Hospital, é plantonista e executa o procedimento há 32 anos; é católico praticante.

Dionísio, médico, 50 anos, casado, têm dois filhos, exerce a profissão há 24 anos, trabalha no Hospital, é plantonista e executa o procedimento há 24 anos, é espírita praticante.

Láquesis, médica, 55 anos, casada, têm 02 filhos, exerce a profissão há 32 anos, trabalha em Hospital, é plantonista e executa o procedimento há 32 anos; é católica não praticante.

Hefesto, médico, 57 anos, casado, têm dois filhos, exerce a profissão há 32 anos, trabalha em Hospital, é plantonista e executa o procedimento há 32 anos; é católico não praticante. 
Eufrosina, psicóloga, 54 anos, casada, têm 02 filhos, exerce a profissão há 30 anos, trabalha em Unidade Básica de Saúde com planejamento familiar há 01 ano; é católica praticante.

Graças, psicóloga, 28 anos, casada, não têm filhos, exerce a profissão há 08 anos, trabalha em Unidade Básica de Saúde com planejamento familiar há 04 anos; é católica não praticante.

Tália, psicóloga, 46 anos, casada, têm 02 filhos, exerce a profissão há 06 anos, trabalha em Hospital com planejamento familiar há 06 anos; é católica praticante.

Agalaia, psicóloga, 52 anos, casada, têm 02 filhos, exerce a profissão há 28 anos, trabalha em Hospital com planejamento familiar há 10 anos; é evangélica praticante. 


\subsection{Concepção dos profissionais sobre a esterilização como método contraceptivo.}

\subsubsection{A esterilização como opção de método contraceptivo.}

Notadamente no campo da Saúde Pública, a esterilização cirúrgica sempre se apresentou como controversa e a sua regulamentação pela lei representou colocá-la como uma atividade reconhecida, no entanto, se observa pela natureza de sua prática um procedimento revestido de complexidade que pode ser evidenciado em muitos discursos profissionais. Isso é o que podemos observar na fala da psicóloga Eufrosina, apresentada a seguir:

Quando o casal vem procurar a gente pra um trabalho, já pra participar do planejamento familiar, a gente sabe que eles já pensaram sobre o assunto, mas primeiro a gente tem que tentar mostrar pra ele todos os métodos que existem antes desse, que é uma cirurgia, há um risco, e a gente tenta mostrar pra pessoa interessada que talvez ela precise explorar outros métodos antes. Há também, do ponto de vista psicológico, uma coisa assim, o casal está junto hoje, mas e se daqui a dois, três anos não estiverem mais, começarem a gostar de outra pessoa, quiser ter outra família, a gente tenta explicar isso pra pessoa, que um método definitivo pode transformar a vida dele no futuro e vir um arrependimento. Então a gente tenta primeiro convencer, mas se a pessoa mostrar que ela está firme no que ela quer, nos responder que já tentou outros métodos e que está consciente que não quer mais ter filho, a gente pergunta também se conhece parentes ou amigos que também já fizeram a cirurgia, como essas pessoas estão, e quando a gente percebe que a pessoa tá firme dentro do propósito a gente não há o que ser contra a pessoa, ao desejo dela e ao direito dela.(Eufrosina, psicóloga, 54 anos, trabalha em UBS, católica praticante).

Em sua fala, Eufrosina destaca os aspectos relacionados ao método que fazem da esterilização e da lei 9263/96 um capítulo à parte, isto ao levantar questões relativas à importância do casal refletir sobre o assunto, ter conhecimento dos diferentes métodos existentes, para além da esterilização, as implicações para a vida conjugal tendo em vista que o mesmo se constitui em 
método definitivo que pode trazer implicações na vida futura e, no caso de separação e novo casamento, relacionado a um arrependimento por ter adotado um método definitivo (CUNHA, 2007; VIEIRA, 2007). Com isso, Eufrosina aponta a importância da definição de uma filosofia de trabalho que os profissionais oferecem aos usuários e somente a partir de um grande diálogo e amadurecimento da decisão do casal o serviço liberar, tendo em vista contemplar o seu direito prescrito pela lei.

Apresentando o mesmo nível de preocupação, o relato de Zeus, médico, aponta as qualidades e limites da esterilização feminina, como masculina, como prática de saúde.

Pra mim, é um método que têm indicações, nas quais ele é muito bom. Ele, tanto a esterilização feminina, como a masculina, para indivíduos que consideram seu potencial reprodutivo já como estabelecido, ou seja, que não desejam ter mais filhos, eu acho que são métodos muito interessantes, porque eles, apesar de terem riscos próprios do procedimento em si, mas eles têm uma eficácia bastante alta, ainda que não seja de cem por cento, e evita a necessidade de utilização de outros métodos com todas as dificuldades que, às vezes, eles trazem, com todos os efeitos colaterais, particularmente no uso de métodos medicamentosos. Então eu acredito que dentro de determinadas condições são métodos muito bons pra você garantir uma limitação do potencial reprodutivo, o que pra algumas pessoas é fundamental (Zeus, médico, 51 anos, trabalha em hospital, não é adepto a nenhuma religião).

Pelo discurso de Zeus, a esterilização têm indicações que considera importante dentro da perspectiva da saúde. Em sua narrativa coteja os riscos e benefícios, quer para esterilização feminina como masculina, sobretudo aos casais que não desejam mais ter filhos por julgarem adequados a sua prole já constituída, o que possibilitam liberar as mulheres de efeitos de métodos medicamentosos relatados em trabalhos sobre o tema (CARVALHO e SCHOR, 2005). A literatura aponta igualmente que, nos países menos desenvolvidos, os métodos mais prevalentes no mundo, são a esterilização cirúrgica e a pílula 
anticoncepcional respectivamente (UNITED NATIONS POPULATION DIVISION, 2005).

Daí, a importância da questão da esterilização não ser tratada de maneira isolada de uma concepção de planejamento familiar, que contemple a multiplicidade de métodos podem ser observados em muitos discursos a seguir:

É eu acho assim, se o casal ou a mulher, né, que decidir fazer ela já optou por todos e, realmente, ela não deseja mais ter filhos, e principalmente se for por uma questão clínica eu acho que ela pode participar, sim, do processo. Se ela tá respaldada na lei, também (Tália, psicóloga, 46 anos, trabalha em Hospital, católica praticante).

Eu acho um bom método, é... Um novo método praticamente definitivo, né, e seguro, principalmente em situações que você realmente quer uma garantia em relação a isso, em situações que a paciente apresenta patologias de risco. Eu acho um bom método (Nikê, médica, 48 anos, plantonista, espírita praticante).

Eu acho que é um método como outro, agregado ao arsenal de todos os métodos que a gente tem é um método definitivo. Eu considero importante que todas as mulheres e homens tenham acesso à esterilização cirúrgica, tá, mas não o considero como o único método que deva ser colocado para que o paciente tome a sua decisão (Láquesis, médica, 55 anos, plantonista, católica não praticante).

Por outro lado, a questão de entender a peculiaridade que a esterilização assume no conjunto dos vários métodos contraceptivos, pelas implicações que encerra para projetos de vidas futuros, encontra-se igualmente presente em alguns dos discursos de profissionais de diferentes áreas:

Eu acho um excelente método, desde que a paciente esteja, assim, convencida de que isso seria o melhor pra ela, que ela tivesse maturidade pra poder ter essa escolha, né (Átropos, médica, 41 anos, trabalha em Hospital, católica não praticante).

Eu acho que é um excelente método, desde que adequadamente escolhido 
e com consciência. Eu acho que é um excelente método. (Deméter, médica, 55 anos, trabalha em UBS, católica não praticante).

É um método definitivo, a paciente, o casal que for optar por esse método, ela tem que tá ciente que é um método definitivo, não é, na realidade, um método que ela pode escolher e depois rever a opção dela, né. Então, assim, eu tenho no planejamento familiar um espaço que deixa claro, né, que passa as informações e que o casal, ou a esposa, o marido, fica ciente, né, do que é o método, quais as vantagens e as desvantagens de cada método (Ártemis, assistente social, 46 anos, trabalha em UBS, católica praticante).

Como se pode observar pelas falas acima, esse método assume peculiaridades por envolver maturidade no processo de decisão por se tratar de um método definitivo, com implicações para a vida do casal, presente ou futura, não se tratando, assim, de uma decisão individual e não reflexiva para projetos de vida futuros.

\subsubsection{A esterilização como último recurso.}

Se nos discursos anteriores pudemos observar que, na perspectiva de profissionais, a esterilização passa a ser considerada, a partir da lei 9263/96, como método contraceptivo no contexto do planejamento familiar, a ideia presente é que o mesmo deva ser contextualizado não somente levando em conta os critérios clínicos, mas igualmente suas implicações do ponto de vista social, uma vez que se trata de um método considerado definitivo ou de difícil reversão; com grande eficácia, portanto deve ser considerado como ultimo recurso, ideia presente na totalidade das falas de profissionais.

$\mathrm{Na}$ fala de Atena, podemos observar o porquê da esterilização comoúltimo recurso pela complexidade que envolve, quer em nível da decisão individual, quer em nível da decisão/realização pelo serviço de saúde.

Então, em minha opinião ela é uma alternativa de contracepção, com toda 
certeza. É uma alternativa radical, ela é um procedimento, é uma decisão que deve ser amadurecida. Eu penso que o Estado, a saúde pública têm uma responsabilidade de dar a informação de qualidade para a tomada de decisão, mas nenhum dos profissionais, nenhum dos profissionais que interagem com essa temática decide pela pessoa. Penso que você deva... A saúde pública deva oportunizar a informação, desmistificando, pondo... Qualificando a informação pra que a pessoa tenha noção de riscos, de possibilidades, e que existem métodos anteriores à esterilização cirúrgica, que existem procedimentos que não são tão radicais e, portanto, são reversíveis. Penso que na saúde pública, atualmente, a gente trata o método de esterilização como algo irreversível, e eu, no meu trabalho, conduzo à entrevista de reflexão, preferencialmente com o casal, captando desse casal, padrão de relacionamento, padrão cultural, expectativa de vida futura e as determinações principais pra tomada de decisão. A decisão, ela é sempre datada, né, o casal toma a decisão em função de alguma situação de vida que ele tá passando, de satisfação com o número de filhos ou de insatisfação da qualidade do relacionamento, da situação financeira, enfim, são várias as situações, mas eu acho que a gente tem que se assegurar de que a eles foi dada a possibilidade de uma decisão com qualidade na informação técnica (Atena, assistente social, 50 anos, trabalha em UBS, católica não praticante).

Conforme podemos observar, embora a esterilização passe a partir da regulamentação através da lei 9263, a constar como um dos métodos alternativos da mulher. Pode-se observar pela fala de Atena o reconhecimento, pelos próprios profissionais que se trata de uma alternativa radical, pelas implicações que encerra por se tratar conforme já observado, de um método considerado definitivo. $\mathrm{Na}$ fala de Atena, observa-se assim, as responsabilidades que se reveste 0 campo da Saúde Pública em ações de planejamento familiar, de se contemplar em nível dos serviços uma gama de ações que possibilite a mulher ou ao casal amadurecer o seu processo de decisão com ações específicas desenvolvidas pelo próprio serviço.

As falas de outros profissionais apontam para a mesma direção, mas 
apresentam nuances que merecem destaques; como é o caso das falas de Agalaia e Eros que discorrem sobre o significado da laqueadura no contexto da contracepção, mas igualmente as condições que devem ser consideradas para a realização deste procedimento.

Eu acho que é um recurso a ser utilizado quando os outros métodos não estiverem atendendo às necessidades dos usuários, né. Eu acho que deve ser utilizado, mas como último recurso. Quando eles fizeram o uso, né, de outros métodos, e não tiveram uma boa resposta ou não se adaptaram a esses outros métodos (Agalaia, psicóloga, 52 anos, trabalha em Hospital, evangélica praticante).

Bom, eu, particularmente, em relação à esterilização definitiva eu tenho algumas ressalvas. Não é um método que eu escolha de rotina, né, pra mim é um método de exceção de contracepção. Eu acho que deve ser um método indicado em casos muito bem estabelecidos, muito bem estudados. Particularmente, nos casos de grandes multíparas, de pacientes com cesáreas iterativas e pacientes de alto risco, com gestação de alto risco, né. Eu acho que esses casos são bem estabelecidos pra um método definitivo, caso contrário eu dou sempre preferência aos métodos reversíveis.

(Eros, médico, 56 anos, trabalha em UBS, espírita praticante).

$\mathrm{Na}$ fala de Agalaia, psicóloga, podemos observar que a ideia da esterilização como último recurso relaciona-se diretamente ao fato de outros métodos terem sido utilizados e não terem atendido às necessidades dos usuários pela falta de adaptação ou eficácia.

No discurso de Eros, médico, ressalta que não se trata de uma prática contraceptiva como escolha de rotina, isto por entender que se trata de um método indicado em casos bem específicos, relacionados aos indicadores de riscos clínicos para a mulher.

Se para Eros a indicação se circunscreve notadamente ao risco clinico, na fala de Ares, médico, a questão da decisão para o procedimento vai além dos mesmos, por envolver questões de natureza psicossocial decorrentes da condição em que se encontra a mulher, conforme relatos a seguir: 
Acho, no caso de uma esterilização cirúrgica, tem que ser um assunto para ser muito bem abordado, né, entre o casal, né. Eu acho que se você for uma pessoa muito jovem, eu acho que é o arrependimento, no futuro, pode ser maior e pode ser que não tenha reversão na situação, né. Eu não... Com sinceridade, eu não sou muito a favor da esterilização cirúrgica, principalmente na laqueadura na mulher, né. Eu sou mais resistente pra liberar a laqueadura. Agora, outros métodos a gente pode até sentar e conversar. Porque a laqueadura, em si, eu acho que é uma agressão no corpo feminino que ela... a maioria das mulheres chegam pra mim e perguntam se dá pra laquear, se é o último filho vem desesperada porque não tá na hora, né, porque não tava esperando e coisa e tal, e geralmente são pessoas jovens, assim Que engravidaram menos.. Elas dizem sem querer, né. Eu acho que a esterilização na mulher muito jovem é muito agressiva e acho que o momento certo não é durante a gravidez só porque engravidou e não queria né. Eu acho que o negócio é pensar antes, conversar antes, planejar antes. Por isso que chama planejamento familiar. E é a gente que tem a obrigação, primeiro, de oferecer os meios, né... Os meios e explicar as consequências, as vantagens, desvantagens dos métodos, né. (Ares, médico, 46 anos, trabalha em UBS, católico praticante).

No discurso de Ares podemos observar que a idade ou a juventude da mulher, trata-se de um indicador importante a ser considerado na decisão para esterilização cirúrgica porque seu discurso estreitamente relacionado ao que a literatura discute como as maiores possibilidades de arrependimento futuro, representa uma das questões mais controversas da lei.

Tratando da questão do arrependimento, CURTIS (2006), relata que as mulheres submetidas à esterilização cirúrgica antes dos 30 anos estavam vulneráveis a duas vezes mais chances de arrependimento; em nosso meio BARBOSA e col. (2009), constataram que a chance de uma mulher com 35 anos ou mais se arrepender é 69\% menor que uma mulher com menos de 25 anos, HARDY e col. (1996) revelaram que o risco de solicitarem a reversão da esterilização para mulheres que fizeram a cirurgia antes dos 25 anos é 18 vezes 
maior do que para aquelas cuja esterilização foi realizada depois dos 29 anos ou seja , ocorre uma relação inversa entre o arrependimento e a idade da realização da esterilização cirúrgica.

Além da questão da idade precoce o discurso de Ares, apresenta igualmente em seu discurso a questão da forma como as práticas médicas se apropriam muito mais do corpo da mulher, que do corpo masculino no contexto do planejamento familiar.

Isto pode ser evidenciado quando observamos que um dos métodos mais utilizados em diferentes países, é a esterilização cirúrgica, ao lado da pílula contraceptiva, como por exemplo, nos países em desenvolvimento como o Brasil, sendo que no mundo ainda é o método com maior prevalência (UNITED NATIONS POPULATION DIVISION, 2005).

Diante de tais considerações podemos observar o quanto, por exemplo, do colocado nos discurso de Ares e Atena, que introduzem este tema, os desafios que se colocam à prática da esterilização cirúrgica no contexto dos vários serviços de saúde. 


\subsection{Concepção dos profissionais sobre a regulamentação da lei 9263/96.}

\subsubsection{A regulamentação como disciplinadora da prática médica.}

Por muitos anos a prática da esterilização no Brasil aconteceu em um cenário de clandestinidade, na medida em que eram interpretadas do ponto de vista jurídico como ofensa criminal, com base no Código Penal de 1940, Artigo 29, Parágrafo 2 III, e, segundo o Código de Ética Médica, a realização da esterilização cirúrgica era proibida, até 1988, salvo em algumas situações especificas de risco de vida (BERQUÓ, 2003; CARVALHO 2007).

Esse contexto de ilegalidade contribuiu para que se verificassem várias distorções na prática da esterilização como, por exemplo, no caso da laqueadura, a realização de cesariana apenas para encobrir a cobrança adicional, e a sua realização em mulheres muito jovens e com poucos filhos, sob o maior risco de arrependimento (HARDY, 1996; VIEIRA, 1994, 1998).

Diante das características de ilegalidade da esterilização cirúrgica antes da regulamentação, que apesar da proibição era praticada por profissionais de saúde em larga escala, sendo considerado, portanto uma ação passível de julgamento por lesão corporal grave, a quase totalidade das falas apresentam um discurso da importância das mesmas para as práticas em saúde, conforme anuncia Zeus:

De uma forma geral eu acho que a lei foi boa, por que... Primeiro porque ela veio a retirar parte de um aspecto que era muito desfavorável nesse tema, uma vez que era um procedimento realizado de forma muito frequente no país, na absoluta maioria, na verdade, na totalidade das vezes ele era considerado ilegal. Porque a única regulamentação que havia era o Código Penal, que proibia, independente da situação, qualquer forma de esterilização em seres humanos, digo, em cidadãos brasileiros e, portanto, eu acho que ela, ao surgir, ela veio tirar um pouco essa sombra que pairava quando da realização de procedimentos desse tipo, que como eu disse anteriormente, eu considero bastante interessante em algumas situações (Zeus, médico, 51 anos, trabalha em hospital, não é adepto a nenhuma 
religião).

Nesse sentido a ideia de respaldo à prática profissional apresentou-se com expressão nos discursos de Ártemis e Era, não somente para os médicos, mas também para os usuários.

Eu acho que assim, veio fortalecer, né, uma decisão, já anteriormente discutida, e que isso veio dar respaldo aos profissionais e aos pacientes. (Ártemis, assistente social, 46 anos, trabalha em UBS, católica praticante).

Eu acho que favoreceu, e muito. Porque a lei trouxe respaldo, não... né, trouxe uma segurança pra pessoa que quer fazer, como pra equipe médica que tá atendendo, aqui, aquele caso, aquela pessoa. Então eu acho que ele trouxe respaldo para os dois lados (Hera, enfermeira, 42 anos, trabalha em UBS, evangélica praticante).

A prática indiscriminada que caracterizava a realização da esterilização antes da lei envolvia, conforme relato de Graças, a questão do pagamento e de uma decisão sem nenhum processo de orientação, cuja decisão irrefletida, muitas vezes implicava em arrependimento. Daí Graças, psicóloga, reconhecer a importância que a regulamentação trouxe ao definir essa prática acompanhada de um processo de orientação por equipe multidisciplinar.

Antigamente se você pagava você tinha acesso, né, de tá fazendo a cirurgia. Hoje, não. Hoje você não paga, né, se você solicita você faz o planejamento e faz a orientação, tem esse propósito, a orientação. Porque antes não tinha, antes você chegava pro médico particular e você falava assim "Quero fazer, eu não quero ter mais filhos", pagava, não tinha nenhum planejamento, nenhuma orientação, por isso que teve muita gente que eu já conheci que se arrependeu e teve que tentar fazer uma reversão, no caso, porque não houve essa orientação antes, né. E com esta lei teve, tem um planejamento, tem a orientação, tem a informação, e aí, sim, teve mais acesso tanto pras mulheres como para os homens, e isso é um grande avanço (Graças, psicóloga, 28 anos, trabalha em UBS, católica não praticante). 
O reconhecimento de que se tratava de uma prática frequente, a despeito da ilegalidade encontra-se presente em vários discursos de profissionais médicos conforme abaixo. Reconhecendo que a lei não só traz o respaldo anteriormente mencionado, mas atende a uma prática que muitos médicos acreditavam serem favoráveis às mulheres em alguns casos que vão desde os direitos da mulher, a aqueles que possibilitariam o melhor registro das próprias atividades de saúde, relacionados a alguns processos de intervenção como a realização de cesáreas com laqueadura, não registrados em prontuário.

Eu já fazia laqueadura, mas eu acho que a lei deu uma segurança maior ao profissional médico. Depois que isso foi colocado dentro de uma lei, então você faz a laqueadura com maior segurança, sem medos de processos, desde que você siga corretamente a lei. Acredito que a maioria dos médicos sempre fez a laqueadura, principalmente nas pacientes que já tinham prole constituída, que não queriam mais filhos e não queriam outros métodos, a gente acabava fazendo laqueadura, sim, independente da existência da lei, ou não, mas com medo, porque é considerada lesão corporal grave, né. (Deméter, médica, 55 anos, trabalha em UBS, católica não praticante).

Eu acho que antes era muito mais radical a história de lesão corporal, de considerar como uma lesão corporal grave e de você não poder executar 0 procedimento. Hoje eu acho que ela é um pouco mais livre, existe uma discussão sobre o processo, você tem direito, mesmo em situações que antes você não considerava... você pode estar discutindo hoje, né, de... mesmo a um casal jovem. Eu posso não ser tão favorável a um casal de vinte e cinco anos decidirem, mas, ele tem essa possibilidade. Eu acho que a lei te dá essa possibilidade, hoje. Eu vejo como um direito a questão da escolha da fertilidade (Nikê, médica, 48 anos, plantonista, espírita praticante).

Era pior porque era proibido, os médicos tinham medo, tinham medo de ser preso, tomar processo. Então eu acho que com a lei foi bem melhor do que sem a lei, era praticado meio escondido, né, aquela coisa que você faz, mas que não tem um amparo, então a pessoa, às vezes, até omitia de descrição cirúrgica, né. Acabava sendo uma escolha de momento, ou fazia o paciente 
assinar vários termos de consentimento. Eu achei que com a lei foi melhor porque vocês... Os médicos acham que se sentem mais seguros em praticar a laqueadura. A gente pode questionar a lei em si, mas assim, eu acho que em relação. Entre ter a lei e não ter foi muito melhor ter a lei, né. (Átropos, médica, 41 anos, trabalha em Hospital, católica não praticante).

A questão da relação entre cesáreas e laqueadura como prática corrente no Brasil, foi reconhecido em vários trabalhos destacando-se o de Elza Berquó quando mencionava esta relação nos anos de 1990 como um caso exemplar no nosso país. Esse nível de preocupação apresenta-se igualmente presente no discurso de Aristeu e Calíope.

É eu acho que, no meu entender, essa lei obedece... Tem uma motivação econômica, eu acho fortemente econômica. Eu digo o fato pra diminuir o índice de cesárea pra realização de laqueadura. Por outro lado eu acho que haveria... Ainda existe um abuso, né. A gente vê muito abuso, assim, na orientação, na prática, inclusive. Teve o lado positivo de regulamentar, de... Não regulamentou, na verdade, né, ele não... Os médicos não continuam seguindo muito, ainda. Mas em termos, assim, gerais, houve certa normatização e disciplina. Os médicos passaram a ser mais disciplinados. (Aristeu, médico, 54 anos, trabalha em UBS, católico praticante).

No caso de Calíope seu discurso vai além, no sentido de que a legislação ao definir critérios, ela oferece parâmetros para decisões médicas beneficiando o próprio processo de orientação.

Então, eu acho que o benefício dela foi criar esses critérios exatos, o que facilitou não só indicar, mas também esclarecer pras pacientes quando ela se enquadraria ou não, né. Dificultou um pouco pra quem era mais liberal e fazia inadvertidamente, por outro lado nos deu argumentos pra conversar com essa paciente, explicar os casos que entram ou não nessa regulamentação. Então eu acho que foi benéfico. Porque, antigamente, como tinham... Esses critérios dependiam da consciência de cada um, a impressão que eu tenho é que, diferente do serviço particular, nos serviços públicos muitos profissionais não a realizavam. E agora tendo essa regulamentação, tendo essa comissão, os outros métodos, eles se sentem 
mais à vontade e mais respaldados pra realizar o procedimento (Calíope, médica, 38 anos, trabalha em Hospital, espirita não praticante).

\subsubsection{A regulamentação como ampliadora do acesso à esterilização cirúrgica.}

A lei 9263/96 surge no Brasil, no contexto de luta pela conquista dos Direitos Sexuais e Reprodutivos (ÁVILA, 2003). Esses direitos podem ser traduzidos como um direito do livre exercício da sexualidade e principalmente da autonomia das decisões individuais e dos casais, e garantem o direito a uma sexualidade saudável sem o risco de uma gravidez indesejada, que também foram referendados pela Conferência Mundial sobre a Mulher, em Beijing, em 1995 (ONU, 1996).

A concepção dos profissionais a respeito da esterilização cirúrgica, como um direito, a partir da regulamentação da lei 9263/96 se encontra presente nos discursos de Ártemis e Átropos como exposto a seguir:

Primeiro, que é um direito que é regulamentado. Segundo, que respaldo o usuário e os profissionais, né. Terceiro, que você vai exigir uma reestruturação, uma melhoria nos serviços de saúde que possam oferecer esse direito, né, esse direito pro paciente (Ártemis, assistente social, 46 anos, trabalha em UBS, católica praticante).

Em relação à paciente, também. Porque eu acho que ela tá mais... Você tem um respaldo pra dizer "Olha, por lei você tem esse direito. Eu posso até não concordar em fazer em você, mas você tem o direito, por lei, de „tá" fazendo", então você também respalda o direito do paciente. Apesar de que eu acho que às vezes o governo não deveria interferir nisso, deveria talvez ser muito mais um desejo do casal e um procedimento realizado, desde que o médico também se sentisse confortável em fazer (Átropos, médica, 41 anos, trabalha em Hospital, católica não praticante).

A fala de Atena vai além de um simples direito, a esterilização cirúrgica 
passou a ser um direito reclamável, deixando de ser a liberação do procedimento uma simples decisão dos profissionais de saúde, com critérios sujeitos às subjetividades de sua moral, de sua trajetória profissional, de sua religiosidade e, sobretudo das suas convicções pessoais.

Eu acho que a legislação traz uma padronização e torna o direito... A hora em que você formaliza no campo jurídico, você torna o direito reclamável. Mas eu considero que a lei dá o caráter de direito reclamável. É possível você, ao não conseguir fazer no SUS, você reclamar por este direito. Então eu acho que isso é um avanço e tira a prática "meritocrática", os profissionais, ele merece fazer ou não, moralmente, por critérios, às vezes, subjetivos, da trajetória do profissional, da sua moral, da sua religiosidade, das suas convicções. Então eu acho, eu sou plenamente favorável, eu acho que ela poderia ser melhorada, mas eu acho que é fundamental você ter estabelecido no plano jurídico formal porque dá possibilidades, né, os casais se movimentarem nisso quando torna esse direito reclamável (Atena, assistente Social, 50 anos, trabalha em UBS, católica não praticante).

Os princípios doutrinários do Sistema Único de Saúde são a Universalidade, a Equidade e a Integralidade. Os princípios organizacionais são a descentralização, a regionalização e a hierarquização, e a participação popular (BARATA e col., 2004).

A universalidade, segundo esse princípio a saúde é um direito de todos e é um dever do Estado na provisão de serviços e de ações de saúde a todos que deles necessitem, todavia, enfatizando as ações preventivas e reduzindo o tratamento de agravos (MINISTÉRIO DA SAÚDE, 2000).

A equidade pode ser entendida como o reconhecimento das diferenças existentes nas necessidades, quer seja regionais ou individuais, com ações que promovam justiça social, que reduzam a exclusão e beneficiem prioritariamente aqueles que possuem piores condições de saúde (BARATA e col.,2004).

A integralidade poderia ser compreendida como; mediante a articulação de ações e serviços preventivos, curativos, individuais e coletivos, necessários à efetiva melhora dos níveis de saúde da população (BARATA e col.,2004). 
Antes da regulamentação da lei, a esterilização cirúrgica envolvia uma prática com total falta de compromisso com um dos princípios fundamentais do SUS, que é a Equidade, ou seja, "dar mais a quem precisa mais"; no caso da esterilização cirúrgica quem mais precisaria ter acesso é a população mais carente em comparação com a mais rica. A identificação desta distorção se encontra presente nos discursos profissionais de Eufrosina e Láquesis:

Eu acho que veio ajudar a grande maioria da população carente, principalmente, quem precisa, se a gente for analisar é a população que mais filhos têm, porque a população que tem condição, que tem poder aquisitivo, na grande maioria tem um ou dois filhos, três, no máximo, são poucos os que têm mais de três filhos. $E$ a população que a gente vê que tem muito, cinco, seis, sete filhos, até oito, hoje em dia já é uma quantia menor, mas tem, é a população carente, é a população que mais usa o Sistema Único de Saúde. Porque antes a gente tinha aquelas pessoas que conseguiram fazer uma cirurgia porque tinham poder aquisitivo (Eufrosina, psicóloga, 54 anos, trabalha em UBS, católica praticante).

Eu achei muito positivo, achei extremamente positivo. Porque até essa data a maioria das mulheres que tinham acesso à esterilização, elas pagavam. Depois da lei ela foi assumida pelo Estado, o Estado passou a provedor, passou a fazer a esterilização cirúrgica, e não mais a mulher procurar um médico que ela fosse pagar e se dispusesse a fazer. Então provocou... A partir da lei, realmente a gente atendeu a um dos pilares do SUS, que é a equidade, né. Até a promulgação da lei não havia equidade (Láquesis, médica, 55 anos, plantonista, católica não praticante)

Nesse sentido, a regulamentação da esterilização tornou possível o cumprimento do princípio da Universalidade do SUS garantindo e ampliando o acesso a todos os cidadãos, que se encontra presente em muitos discursos profissionais a seguir:

Eu acho que sim. Ficou muito mais fácil, a paciente vai e faz o planejamento familiar numa unidade, se ela estiver de acordo com a legislação ela é encaminhada pra fazer a laqueadura, o marido pra fazer a vasectomia, dentro, já, de uma lei pré-estabelecida. Então eu acho que facilitou o acesso, 
sim, e tornou esse acesso universal. Eu achei perfeito, porque antigamente, assim, quem tinha dinheiro pagava um médico e quem não tinha, tinha trinta filhos, então eu acho que não é por aí. $O$ acesso à saúde tem que ser universal (Deméter, médica, 55 anos, trabalha em UBS, católica não praticante).

A importância pra conseguir, pra toda a população ter acesso, né, porque antes quem fazia a laqueadura era quem pagava né, laqueadura e vasectomia, e através dessa lei o SUS faz e aí qualquer pessoa tem acesso. (Nêmesis, enfermeira, 52 anos, trabalha em Hospital, católica praticante).

É aquilo que eu te disse. Foi um avanço porque deu liberdade, liberou pra que as pacientes com baixo nível sócio-econômico conseguissem uma laqueadura, tá. Porque antes era muito difícil, tá. Agora, a gente sabe que isso aumentou muito e deu oportunidade pra muitas mulheres, tá, por questões realmente sócio-econômicas, desfavoráveis, que não se faziam e hoje faz, tá. Eu acho que isso veio a calhar. Eu dou valor, sim, à lei, eu acho que a lei veio pra melhorar. Porque muitas... Dos casais, eles não têm condições financeiras, tá, e perante uma lei eles possam usufruir desse, dessa vantagem, e de repente é uma vantagem porque eles não vão ter mais gasto com métodos anticoncepcionais e vão estar mais tranquilos, tá, pra eles terem uma liberdade conjugal melhor (Hefesto, médico, 57 anos, plantonista, católico não praticante).

Considero porque eu acho que ela normatizou. O tempo vai dizer se isso for bom ou mau, se precisa de algum ajuste ou não, mas eu acho que foi um avanço. Porque eu acho que hoje, quer dizer, hoje não, mas antigamente as pessoas, elas tinham um problema de planejamento familiar porque elas não tinham uma cobertura tão ampla de oportunidades pra fazer, né. Então, bem, eu acho que isso melhorou pro paciente, pra quem quer fazer. (Apolo, médico, 57 anos, plantonista, católico praticante).

Apesar da ampliação do acesso após a regulamentação, no discurso de NiKê, podemos observar ainda a preocupação com a lei no sentido de ela ser 
restritiva no parto e pós-parto.

Eu acho que facilitou bastante o acesso da população a realização da laqueadura, com a restrição de não poder ser praticada no ato da gestação, né, do término da gestação. Então por um lado é bom porque a paciente tem uma, acho que tem uma clareza maior no momento da decisão, por outro lado ele deixa de aproveitar um momento que às vezes é mais favorável pra prática de esterilização. (Nikê, médica, 48 anos, plantonista, espírita praticante).

Vale considerar que o "espirito da lei", conforme já apontado por BERQUÓ e CAVENAGHI (2003), visava a coibir a indicação de cesáreas para fins exclusivos de esterilização. Entretanto, ao tornar proibitiva no momento do parto, impediu a prática da laqueadura após um parto normal, procedimento este praticado antes da regulamentação da lei 9263/96 o que será objeto de crítica. Essa situação ocorria quando a gestante tinha uma autorização para laqueadura no decurso da gestação. Esse tipo de critica também se encontra presente na literatura já descrita na introdução desse trabalho. A discussão é trazida em relação a esse aspecto notadamente por Rosas, em 2001, quando aponta que a legislação é restritiva quando aplicada à mulher na condição de gestante, proibindo a laqueadura tubária durante os períodos do parto, aborto e puerpério. (MARISCAL, 2001). 


\subsection{A esterilização cirúrgica na prática dos serviços de saúde.}

\subsubsection{Sobre a oferta de métodos contraceptivos.}

O art. 9 da lei 9263/96, reza que "para o exercício do direito ao planejamento familiar, serão oferecidos todos os métodos cientificamente aceitos de técnicas de concepção e contracepção, que não coloquem em risco a vida e a saúde das pessoas e que seja garantida a liberdade de opção". (LEI 9263/96 anexo I).

O grande desafio em relação ao planejamento reprodutivo ainda reside no fato de nos serviços de saúde haver um suprimento de insumos em quantidades insuficientes, ou seja, pouca disponibilidade dos métodos contraceptivos previstos na lei para atender a demanda, além de haver uma descontinuidade de fornecimento relatada por OSIS (2006), embora segundo o Ministério da Saúde (2007), esta oferta venha gradativamente melhorando.

Nas falas de Hera, Deméter, Átropos e Láquesis, essa tendência a maior disponibilidade de alguns métodos alternativos à laqueadura estão presentes em alguns serviços.

Olha, todos eu não diria, mas eu acho que o Estado oferece uma boa porção de métodos que se pode estar utilizando. Então eventualmente, por exemplo, não é oferecido o implante, mas tem o contraceptivo oral e o injetável, tem o preservativo. Então tem outros recursos além da laqueadura. (Hera, enfermeira, 42 anos, trabalha em UBS, evangélica praticante).

Só não tem alguns mais... Anel vaginal não existe, os implantes, não existe, mas as pílulas anticoncepcionais, o DIU, os injetáveis, preservativo, diafragma, todos eles existem (Deméter, médica, 55 anos, trabalha em UBS, católica não praticante).

Sim, tem anticoncepcional oral, injetável, o DIU, né, só não tem o DIU medicado, né, mas têm preservativo masculino. O feminino eu acho que não tem muito acesso e o implante também não. Não tem implante nem o DIU 
medicado (Átropos, médica, 41 anos, trabalha em Hospital, católica não praticante).

No entanto, vale registrar a fala de Afrodite que enfatiza essa disponibilidade não ser suficiente para atender a necessidade da demanda prevista em lei:

Não, não existem todos os métodos. Infelizmente é um serviço público estadual e não estão disponíveis todos os métodos existentes no momento, né. Por exemplo, nós não temos o adesivo, nós não temos o DIU medicado, né, o DIU com hormônio, nós não temos, ainda, o preservativo feminino. Então, assim, o que nós podemos oferecer são os métodos de barreira, né, no caso, o DIU de cobre, os contraceptivos orais. Nós não temos nem o adesivo, nem o anel vaginal e nem os outros métodos que eu citei anteriormente (Afrodite, médica, 48 anos, trabalha em Hospital, católica não praticante).

Com razoável... Eu acho que tem melhorado bastante com uma razoável incidência. Não é perfeito, não é cem por cento em todas as unidades, existem falhas, mas eu acho que a oferta hoje é muito melhor do que já foi. Tem melhorado a oferta (Láquesis, médica, 55 anos, plantonista, católica não praticante)

A não disponibilidade de todos os métodos apresenta implicações para a prática dos serviços o que leva ao não cumprimento do que prescreve a lei, conforme podemos observar no discurso de Íris a seguir:

A lei é positiva, só que a gente acaba não cumprindo, né, porque não tem a disponibilização dos métodos, não tem essa questão... a parte educativa. Então, com isso, a lei é, ela é positiva, mas a gente não cumpre o que tá aí, né. Você acaba não cumprindo. Hoje? Condom feminino, mesmo o hormonal a gente não tem todos, tá. Deixa eu ver o que mais... é...não tem o transdérmico, o injetável mensal também não tem, o trimestral às vezes tem, tem época que não. O DIU hormonal também não tem, né. Então fica difícil, né. Aí a opção que ela... Restringe a opção, né (Íris, enfermeira, 46 anos, trabalha em Hospital, católica praticante). 
Tais discursos podem ser corroborados pelos dados do Ministério de Saúde, o Relatório de Gestão 2003 a 2006 aponta que no ano 2006 foram distribuídos 18 milhões de cartelas de pílulas combinadas de baixa dosagem, 1,2 milhões de pílulas somente de progesterona, 207 mil cartelas de anticoncepcional de emergência, 542 mil ampolas de injetável mensal, 250 mil de ampolas do injetável trimestral e 176 mil DIU (Dispositivo Intra-Uterino) atendendo a 5.242 municípios (MINISTÉRIO DA SAÚDE, 2007).

A ampliação da oferta de métodos contraceptivos nos serviços de saúde, embora ainda não em quantidade suficiente, pode ser explicada como decorrência de uma maior preocupação de implementação da política de saúde da mulher prevista no II Plano Nacional de Políticas para Mulheres, estabelecendo como metas, para o triênio 2008-2011, a garantia da oferta de métodos anticoncepcionais reversíveis para $100 \%$ da população feminina usuárias do SUS e a disponibilização de métodos anticoncepcionais em $100 \%$ dos serviços públicos de saúde (SECRETARIA ESPECIAL DE POLÍTICAS PARA MULHERES, 2008).

\subsubsection{O processo para aprovação da esterilização pelas equipes.}

Conforme exposto anteriormente, a lei 9263/96 impõe requisitos legais para a esterilização cirúrgica que resumidamente são: a oferta de todos os métodos cientificamente aceitos de técnicas de concepção e contracepção e a garantia da liberdade de opção; aconselhamento por equipe multidisciplinar para desencorajar a esterilização cirúrgica precoce, espera de sessenta dias entre a manifestação da vontade de esterilização e o procedimento, vinte e cinco anos ou pelo menos dois filhos vivos, capacidade civil plena (LEI9263/96).

As ações dos profissionais de saúde, voltadas a cumprir os requisitos legais no processo de aprovação da esterilização cirúrgica se encontram relatados em vários discursos descritos a seguir: 
Normalmente, as pacientes passam pelo planejamento familiar, dentro da unidade de saúde, aí elas passam com a assistente social, educadora, psicóloga, médico, dependendo dos profissionais que existem na unidade. Procuramos sempre fazer com a equipe multiprofissional, pelo menos dois ou três profissionais de categorias diferentes, uma enfermeira e uma assistente social, uma enfermeira e uma psicóloga, um médico. Então, assim, passa por ações educativas, é orientada, quanto a todos os métodos anticoncepcionais, feitas palestras, ela faz a primeira opção, depois ela é novamente reorientada, explicando que é um método definitivo, que não tem volta, e se a paciente persiste após o prazo de sessenta dias ela continua ciente do que quer fazer, a gente encaminha pra laqueadura ou vasectomia. (Deméter, médica, 55 anos, trabalha em UBS, católica não praticante).

As mulheres têm uma aula de planejamento familiar, são oferecidos todos os métodos contraceptivos. Então, é passado por uma equipe "multi", né, primeiro a porta aqui que a gente atende... Primeiro é o serviço social que vai atender, quando vem das unidades básicas, quando essa mulher não tá gestante. Quando ela está gestante é o pré-natalista que dá a solicitação, ela conversa com o médico dela do pré-natal e ele acaba dando a solicitação. A gente faz uma entrevista, inclui esse casal no grupo, né, de orientação, é assinado um termo que fala... Constando ali naquele termo o que pode acontecer após a esterilização, né, que são os riscos, aí, depois de feito todo esse processo a gente encaminha todo esse processo pra equipe, pros médicos que coordenam o planejamento familiar, aí é dado um parecer favorável ou não favorável, de acordo com a lei do planejamento familiar (Eumênides, assistente social, 40 anos, trabalha em Hospital, católica praticante).

Hoje, os casais, eles passam por orientação da equipe médica, eles passam por uma orientação da equipe multiprofissional, né, de todos os métodos, esse casal é avaliado pela equipe médica, pelo serviço social, se nenhum dos métodos atendeu a necessidade do casal aí eles vão pra um grupo de orientação da esterilização cirúrgica, eles são reavaliados pela equipe médica, e aí eles são aprovados, ou não, né, para o procedimento (Agalaia, psicóloga, 52 anos, trabalha em Hospital, evangélica praticante). 
É feito por um grupo de planejamento familiar, um tipo de reuniões, são três ou quatro reuniões. Existe uma avaliação médica, uma avaliação psicológica, uma avaliação da assistente social, e nessa avaliação médica já se tria pra ver se tá dentro do critério, né, e daí é encaminhado pro serviço. (Aristeu, médico, 54 anos, trabalha em UBS, católico praticante).

Destaca-se no discurso de Eufrosina, a importância dada aos vários encontros e a vantagem da avaliação por diferentes profissionais e diferentes olhares, para auxiliar na tomada de decisão consciente e madura dos usuários por um método definitivo:

Começa assim, o usuário vem até a unidade $e$ se inscreve espontaneamente. A gente oferece o serviço, deixa... Tem... Na unidade está escrito os serviços que a gente oferece e por isso ele acaba chegando ao grupo do planejamento familiar. Na nossa primeira entrevista, nós temos várias passagens, na nossa primeira entrevista a primeira pergunta que a gente faz: "Vocês estão conscientes do método que vocês estão querendo?". Porque a gente tenta primeiro... o planejamento familiar não significa cirurgia, planejamento familiar significa, às vezes, ensinar o casal a usar a camisinha, porque às vezes eles não sabem usar. Ou falar pro casal "Olha, existe o método injetável, existe o DIU", a gente tenta explorar os outros métodos, antes. Aqueles que vêm, já com a convicção de que exploraram vários métodos e às vezes falam assim "A mulher não se adaptou", a mulher, por exemplo, às vezes tem pessoas que com o próprio látex da camisinha tem alergia, aí foi usar um método injetável, tem enjoo, foi usar o trans- dérmico, faz ferida embaixo, coceira, então muitos já vem, que tentaram vários métodos e não conseguiram. A camisinha feminina, infelizmente, é o método menos tentado, e quando a gente tenta mostrar causa até estranheza. Então a gente tenta mostrar, a gente abre e mostra como usa, a gente usa, às vezes, até paciente pra mostrar. "Você já usou?", “Já", "Como que é?", vem lá, mostra, mas esse é o que causa mais estranheza, de todos os métodos que a gente mostra. Então são pessoas que, na grande maioria, quando vem procurar, já exploraram a grande maioria dos métodos. No segundo encontro nós, de novo, cansativamente, até falamos pra ele "Gente, nós temos que explorar. Vamos falar, de novo, de todos os métodos", e deixando sempre bem claro pro usuário "Você pode desistir da cirurgia 
quando você quiser. Até no centro cirúrgico. É um direito que você tem, de pensar em desistir". Quando a gente já vai pro terceiro encontro, que é um encontro mais assim, que eles já criaram vínculo com a gente, que a gente já conhece um pouquinho mais o casal, aí que a gente vai fazer algumas perguntas que a gente percebe, também, que eles ficam pensativos, é a pergunta que a gente tem que fazer, obrigatória, "Se você perdesse um dos seus filhos, como que você faria?". Então isso, a gente deixa eles pensarem de novo, a gente marca um encontro de novo, e a gente fala que o método cirúrgico pode ter, se for, principalmente o da mulher, que é mais invasivo, pode correr o risco de cirurgia, como qualquer cirurgia. A grande maioria "opta" por fazer a vasectomia, mas nós temos alguns casos que a mulher quer a laqueadura. Porque nós temos, por exemplo, um paciente que a vasectomia não deu certo, depois de dois anos ela engravidou, então agora ela veio pra laqueadura. Então a gente tenta explorar bastante todos os outros métodos, mas a gente percebendo que a pessoa tá consciente, que a pessoa já explorou, a pessoa responde várias vezes, e se a gente achar que está dentro do padrão da idade, da necessidade, a gente acaba, também, assinando. No nosso grupo, nós temos a assinatura de uma enfermeira, que do nosso grupo participa uma enfermeira, um médico ginecologista e a psicóloga, são três profissionais com abordagens, né, e éticas até, diferentes (Eufrosina, psicóloga, 54 anos, trabalha em UBS, católica praticante).

\section{A preocupação em cumprir um dos requisitos legais de desencorajar a esterilização cirúrgica precoce, como um dever da equipe multidisciplinar no processo de aprovação, se encontra presente no discurso de Íris: \\ Passa por orientação, mas a maior parte das vezes já vem ligado a um pedido médico, seja quando vem do pré-natal externo, né, de nível de atenção primária, já vem com o pedido e isso é encaminhado. A gente tá abordando a gestante, conversando com ela, mas desde o início eu acho que o item aqui que fala de desencorajando a esterilização precoce, isso acontece. Então existem os grupos, né. para aconselhamento ou, às vezes, individual. A equipe... A equipe multidisciplinar tenta desencorajar a esterilização cirúrgica precoce. Eu não sei isso eu tenho bem claro, que eu peguei bastantes pacientes do outro lado, querendo a reversão. Então isso me fez entender mais a questão assim, de desencorajar a esterilização}


precoce. Porque a gente pega aqui, né, o pessoal vem "Ah, eu quero fazer reversão. Quando você vai ver "Ah, eu fiz aos vinte e dois anos. Aos vinte e três anos", ou mesmo depois. Aí ela retorna querendo fazer a reversão, então quando você escuta o outro lado da história fica mais fácil "tá" conversando também com as jovens que vem aqui e solicita, né. Olha, assim, vai mais pela equipe médica, né, pela questão clínica, se assina ou não. Então. aí tendo a assinatura dos médicos. Aí prossegue e aí é realizado (Íris, enfermeira, 46 anos, trabalha em Hospital, católica praticante).

$\mathrm{Na}$ fala de Dionísio se encontra mencionada a necessidade de cumprir outro requisito legal que é o prazo de sessenta dias entre a manifestação da vontade e o procedimento, tendo em vista uma decisão mais consciente por parte de mulheres, homens ou casais na perspectiva do possível arrependimento futuro.

Bom, os pacientes procuram a Unidade Básica de Saúde, tá, onde passam por uma entrevista. Nessa entrevista eles manifestam o desejo de se submeter à esterilização cirúrgica, após conhecer os outros métodos anticoncepcionais. No caso, é uma opção do paciente. Após, feita a opção é dado um prazo de sessenta dias pra arrependimento e esse paciente, então, é encaminhado para um serviço de ginecologia, de cirurgia ginecológica, tá, onde são feitos pré-operatórios e a paciente, então, é submetida ao ato cirúrgico. Toda a paciente tem... Está durante o pré-natal e tem mais do que duas cesáreas, duas ou mais cesáreas anteriores, então ela vai ao hospital com essa carta, passa pela comissão, a mesma comissão que avalia os casos não gestantes, né, aí é aprovado, e com a carta de aprovação da ligadura tubária ela vai ao pronto-socorro do hospital e faz o agendamento da sua cesárea eletiva, né, porque então ela terá duas ou mais cesáreas. (Dionísio, médico, 50 anos, plantonista, espírita praticante).

Apesar do requisito legal acima referido, Hefesto, em seu discurso relata a dificuldade de cumprir o prazo de sessenta dias quando se depara com situações de gestações avançadas, que torna impraticável a espera do prazo legal.

Porque às vezes a paciente chega ao ambulatório já no sétimo mês de gestação, e aí até ela fazer sessenta dias e assinar, ela vai assinar com oito meses, e eu acho que é por causa de trinta dias de diferença e isso não tem 
que bloquear. Se ela cair no meu plantão, no meu dia que eu tenho, e ela tiver com os papéis que ela assinou com dois dias de antecedência, eu vou fazer a laqueadura, tá. Então eu sigo mais ou menos esse... Depois disso que o casal passa, que é feito, isso é seguido para a diretoria pra que tenha mais gente que assina, mais profissional que assina. Volta e ela volta com o papel pronto. Uma via fica no prontuário da paciente e a segunda via fica com a própria paciente pro dia do parto, tá. (Hefesto, médico, 57 anos, plantonista, católico não praticante).

Diferente dos demais profissionais, os médicos plantonistas não participam do processo de aprovação da esterilização cirúrgica, restando a eles apenas a execução do procedimento, sem a possibilitar ao mesmo uma discussão, restando-lhe apenas a decisão pessoal de fazer a cirurgia ou se recusar alegando motivo de foro íntimo previsto no código de ética médica, conforme podemos observar nos discursos de Nikê e Láquesis:

Dentro do serviço que eu trabalho que é aqui, normalmente quando eu recebo a paciente já vem com o processo, já em andamento, né, já realizado. Então ela já passou por entrevista, já fez todo o processo burocrático. Ela já chega aqui com uma carta de autorização, então... E eu só vou realizar mediante essa autorização (Nikê, médica, 48 anos, plantonista, espírita praticante).

Primeiro que a solicitação deve vir, deve entrar via Unidade Básica de Saúde, que deve ser toda a porta de entrada do sistema. O paciente deve receber, fazer parte de um grupo de planejamento familiar, o casal, se houver o cônjuge, se não houver é discutível isso, também, né. Ela deve fazer parte do grupo, deve ser oferecido a ela todos os métodos anticoncepcionais, ela deve ter plena consciência, ela deve pensar e ela deve decidir. Se, é uma decisão consensual do casal, então isso já deve vir pronto para o serviço. Compete ao serviço médico [o médico] Ele simplesmente, ele só executa. Uma vez que o casal tenha passado por toda essa tramitação eu acho que não cabe ao profissional discutir, a não ser que seja uma questão de foro íntimo dele que a gente também deve dar a liberdade dele dizer que não vai fazer por uma questão de foro íntimo dele 
Láquesis, médica, 55 anos, plantonista, católica não praticante)

Como pudemos observar, o processo de aprovação da esterilização cirúrgica envolve o trabalho de uma equipe multidisciplinar comportando várias etapas; tais como, o desencorajamento da esterilização cirúrgica precoce, a oferta de todos os métodos, o prazo de sessenta dias entre a manifestação da vontade e o procedimento, para cumprir os requisitos legais. Na medida em que não se trata de um processo que articula necessariamente decisão e execução, daí ocorrer muitas vezes a não realização do procedimento, uma vez que, em última instância a decisão é de domínio do médico executante que não partilha da mesma visão e decisão da equipe multidisciplinar ou da própria mulher, homem ou casal. Tal fato se deve, sobretudo, ao forte componente moral de que também se reveste a prática da esterilização cirúrgica em nível dos serviços.

\subsubsection{Sobre o significado da equipe multidisciplinar no processo de aprovação da esterilização.}

Em alguns dos discursos profissionais, podemos observar que uma das funções importantes da equipe multidisciplinar para aprovação desse procedimento é a avaliação da maturidade, além de assegurar-se que é uma decisão consciente e segura por parte da usuária como relatado por Eumênides, Nikê e Nêmesis:

Então, a gente trabalha em relação a toda essa parte educativa, né. Então o que a gente verifica mais nesse casal, realmente, é a questão da segurança. Se ele tá orientado realmente, se ele quer buscar outro método, se ele tá seguro do que tá fazendo. Porque, muitas vezes, o maior problema que a gente tem, realmente, é essa questão do arrependimento. Então hoje o casal tem uma situação, né, estão casados, tem uma quantidade de filhos que eles acham que é a correta aí pra esse casal e, de repente, essa situação pode mudar. Então é isso. Então... Mas a equipe tem que, no final, né, tá conversando. Quando a gente vê que é um caso que tá dando muito problema a gente chama a equipe e conversa, cada um vai ter a sua opinião, 
mas todos sempre estão de acordo com a lei aí. A gente não pode esquecer que, né, a gente trabalha com uma lei e a gente sempre tem que tá garantindo o direito do paciente ali. (Eumênides, assistente social, 40 anos, trabalha em Hospital, católica praticante).

Olha eu não tenho acesso a esse tipo de dado, mas eu acho importante. Eu acho que, principalmente, o dado do psicólogo é um dado importante porque ele vai avaliar, realmente, se aquela pessoa tem uma maturidade pra tomar uma decisão desse tipo ou se ela tá simplesmente motivada por alguma situação específica que ela esteja vivenciando no momento (Nikê, médica, 48 anos, plantonista, espírita praticante).

É porque tem que, pra fazer uma laqueadura a pessoa tem que estar muito certa disso, então tem que sempre colocar pra mulher que é um método definitivo. Então quando ela passa com a psicóloga, a psicóloga vai perceber, ou vai perceber se esse casal está certo dessa atitude, né, dessa conduta. Então por isso que o médico também tem que levar em consideração, porque senão, se tá escrito lá que o casal tá meio assim, não tem certeza, então não deve ser feito. (Nêmesis, enfermeira, 52 anos, trabalha em Hospital, católica praticante).

A atuação multiprofissional com as diferentes visões de mundo na avaliação dos aspectos sócio- econômicos, a maturidade, os aspectos de saúde, ou seja, um conjunto de informações como fundamentais no processo de aprovação se encontra presente nos discursos abaixo:

Eu acho que, assim, o relatório, tanto do serviço social como das psicólogas, é de extrema importância. Na consulta médica nós não conseguimos todas as informações que a assistente social e a psicóloga numa conversa, num outro tipo de abordagem com a paciente, conseguem captar. Então assim, toda vez antes da consulta médica a gente lê a entrevista do serviço social que traz uma série de informações, uma série de nuances, que muitas vezes no momento da consulta a mulher não traz por uma série de fatores. Muitas vezes o marido é presidiário, ou ela tem uma série de conflitos com o marido, situação de violência ou outras questões, que ela relata pra assistente social, mas ela não aborda na consulta médica. Então eu acho de 
fundamental importância (Afrodite, médica, 48 anos, trabalha em Hospital, não praticante).

Eu acho que todos... A equipe multiprofissional só ajuda, né, eles corroboram, eles veem o aspecto psicológico da paciente, se realmente ela tá ciente do que tá fazendo, se é uma atitude consciente, né, e a assistente social vê o nível sócio-econômico, a condição de ela poder, realmente, ter mais filhos, ou não, então acho que todos os dados, eles ajudam pra uma resolução final.(Deméter, médica, 55 anos, trabalha em UBS, católica não praticante).

É eu acho que o mais importante é assim, a grande vantagem de ser multidisciplinar é você não ter só uma... Só um profissional interagindo com essa paciente, porque a gente sabe que relação entre o profissional da saúde e paciente pode variar de uma pessoa pra outra. Então é comum informações que elas, que elas disponibilizam pra uma já não disponibilizam pra outro, às vezes o entendimento que ela tem da... Do que Ihe é ofertado, a percepção dela é diferente, dependendo da relação. Então eu acho que o melhor, a grande vantagem é ter profissionais que têm abordagem diferente tentando passar a mesma informação, e adquirir dela, também, a mesma informação dela. Isso eu acho importante pra evitar maus entendidos, evitar às vezes um ressentimento pessoal, eu acho que dessa maneira fica uma decisão mais impessoal. (Calíope, médica, 38 anos, trabalha em Hospital, espirita não praticante).

Acho importante. A decisão deve ser feita por uma equipe. Os relatórios devem vir de uma equipe multiprofissional. O médico que examinou 0 médico que conversou com a paciente, que tomou essas informações, a assistente social que vai fazer uma avaliação social dela, sim, que eu acho que é importante. Pesa. É muito importante. O psicólogo que vai fazer uma avaliação dessa relação do casal entendeu da lucidez desse casal. Eu, particularmente, já tive situações que eu use que eu precisei, e graças a Deus tinha um relatório do assistente social e o relatório do psicólogo que ajudaram muito na minha tomada de decisão (Láquesis, médica, 55 anos, plantonista, católica não praticante). 
No processo de aprovação pela equipe multidisciplinar, Eros destaca a importância da análise do que considera como dados objetivos, que é a idade, número de filhos, condição sócio-econômica, assim como, a necessidade de avaliação os dados subjetivos que envolvem a prática da esterilização cirúrgica, como a idade, paridade.

Eu acho importante. O planejamento, ele tem que ter esse tipo de visão multidisciplinar. Porque é importante, não só você ter os dados objetivos de idade, de paridade, de patologias, de antecedentes pessoais, né, mas também ter o perfil psicológico da paciente, porque é evidente que uma paciente que tenha um perfil psicológico lábil, quer dizer, uma paciente que tenha um perfil de uma... de uma paciente muito inconstante nas suas afirmações, evidente que é uma paciente que pode dar problemas, né, é uma paciente que mais facilmente vai se arrepender e vai voltar ao nosso serviço, no serviço de esterilidade, pra tentar uma re-anastomose. Então uma paciente que tenha o perfil psicológico mais concreto, mais firme, evidentemente que a gente tem mais segurança na hora de fazer uma autorização bem embasada e que seja embasada, também, no perfil psicológico da paciente, né. Perfil psicológico, a parte social, né, porque muitas vezes. a gente vê pacientes que dentro dos... Disso que a gente tá estabelecendo, de idade, de prole, a paciente também, muitas vezes tem o nível sócio-econômico muito baixo e passa a ter... Às vezes não tem aquela facilidade de usar um método contraceptivo, não se submete ao uso do DIU, não usa pílula regularmente, então aquilo traz um transtorno muito grande na vida social desse casal em que vai se estabelecendo uma prole muito intensa, muito numerosa, trazendo, assim, uma dificuldade muito grande dentro daquela família, muitas vezes vivendo todos num cômodo só, com cozinha, sala e quarto, tudo num único ambiente, com aquele monte de filhos. Então tudo isso, quer dizer, isso cabe à assistente social, cabe à psicóloga, cabe ao médico, cada um dar a sua opinião e se fechar, então, com um embasamento grande e realmente responsável numa autorização final, e não numa autorização, muitas vezes, até digo um termo assim, meio chulo, mas assim, numa indicação leviana, que a gente comumente costuma ver nas indicações de esterilização tubária, né, esterilização cirúrgica (Eros, médico, 56 anos trabalha em UBS, espírita praticante). 
A necessidade da abordagem das diferentes dimensões humanas que envolvem a esterilização cirúrgica e a preocupação com a tendência dos médicos sem avaliarem apenas os dados clínicos, ou seja, o biológico, muitas vezes se esquecendo dos dados sociais também se encontra presente no discurso de Agalaia:

E qual a importância que você vê nos relatórios do psicólogo, né, se houver, e da assistente social, pra subsidiar a decisão dos médicos? Como que você... Você acha que os médicos dão importância aos relatórios desses profissionais?

Eu não acho que eles não dão muita importância, né. Porque o psicólogo e o assistente social, eles vêm um lado da questão reprodutiva que é o lado subjetivo, não é o lado concreto, o lado objetivo, o lado biológico, exclusivamente orgânico, né, então tanto o psicólogo quanto o assistente social vai ver o quê? O desejo, né, desse casal, vai olhar as condições psíquicas desse casal pra tomar uma decisão dessa natureza. Porque por mais que a medicina esteja avançada esterilização cirúrgica é um procedimento cirúrgico, tem riscos, e muitas vezes a gente, é... Não, não percebe a magnitude desse, dessa intervenção cirúrgica, né, e o psicólogo e o assistente social eles vão olhar isso. Será que esse casal tem recursos psíquicos pra tomar uma decisão dessa? Qual é a melhor cirurgia? Uma vasectomia? Uma laqueadura, né? Qual é a imposição desse casal com relação a essa cirurgia, né? Será que a mulher, mais uma vez, ela tá sendo vítima de uma posição machista em que o homem diz "Não, você faz a cirurgia e pronto!"? Então eu acho que a abordagem da psicologia e do serviço social é nesse sentido, né, de escutar um pouco o lado da mulher, escutar um pouco o lado do homem, né, de fazer uma avaliação conjunta com os dois, dessa decisão, olhar as condições sociais, olhar as questões econômicas, né, pra que seja bem indicada uma esterilização cirúrgica.

Eu acho. Eu acho que os médicos, eles valorizam mais as questões objetivas, né. Porque o que é valorizado é: a lei prega isso, então é isso que eu vou fazer. Esta mulher tem, tá dentro do perfil pra esterilização, este homem tá dentro do perfil pra uma vasectomia, então eu vou cumprir a lei e pronto. Então as outras questões, as outras dimensões, né, da situação, eu acho que é pouco valorizada, sim (Agalaia, psicóloga, 52 anos, trabalha em Hospital, evangélica praticante). 
Em sentido oposto, na fala de Erínias, a equipe multidisciplinar no caso da esterilização cirúrgica pouco contribui na decisão dos usuários, pois muitas vezes já é uma ideia fixa ou pré-concebida e difícil mudança nos seus pensamentos:

\begin{abstract}
Normalmente, elas vêm com o pedido já pensado e refletido, de uma decisão de cirurgia definitiva, e elas raramente mudam de opinião, mesmo após reflexões e orientações de equipe multiprofissional. Eu não percebo mudança em pensamento e em proposta de mudança de decisão de cirurgia definitiva pra um método contraceptivo (Erínias, assistente social, 50 anos, trabalha em Hospital, evangélica não praticante).
\end{abstract}

Igualmente no discurso de Aristeu, Apolo e Zeus, médicos, a equipe multidisciplinar têm pouca importância, pois a decisão é centrada na decisão médica e no caso de Zeus o fator determinante na aprovação é o número de filhos, fato este observado no estudo de CARVALHO e col. (2004) intitulado de "número ideal de filhos como fator de risco para laqueadura tubária":

É. Não, sempre ajuda, mas apesar de que na prática privada não se faz muito isso, não segue muito, a gente mesmo faz essa triagem. A decisão é médica em conjunto com a paciente, é lógico, do casal, né (Aristeu, médico, 54 anos, trabalha em UBS, católico praticante).

No serviço público eu acho que eles têm um peso importante, apesar de que eu nunca desconsiderei que esse ato é um ato médico, né. Então quando eu entendia que no aspecto médico não seguia os critérios, eu não fiz (Apolo, médico, 57 anos, plantonista, católico praticante).

Bom, eu vou ser honesto, eu vejo uma importância muito pequena. Quer dizer, eventualmente, se eu tiver alguma informação de que existe algum tipo de distúrbio nessa paciente, nessa interessada, isso pode estar modificando o encaminhamento que vai ser dado, mas eu confesso que a própria lei, ela não trata desse assunto de uma forma tão significativa, e eu acho que realmente, inclusive usando a resposta anterior, como a prole é o que acaba determinando, como o número de filhos é o que acaba determinando essa decisão, eu confesso que eu classificaria como sendo de baixa importância aquilo que me informa o psicólogo, a assistente social e os 
outros profissionais que participam desse processo. (Zeus, médico, 51 anos, trabalha em hospital, não é adepto a nenhuma religião).

Como observado nos discursos anteriores, destaca-se a importância da avaliação das solicitações contemplando as diferentes dimensões humanas, por uma equipe multiprofissional com diferentes visões de mundo, enquanto que alguns profissionais avaliam principalmente os dados subjetivos de natureza psicossocial, como a maturidade do indivíduo na sua tomada de decisão. Podemos observar que notadamente os médicos se centram mais nos chamados dados objetivos como a idade, a paridade, e as questões de saúde. Para alguns dos médicos o número de filhos é isoladamente condição determinante. Assim sendo, a esterilização cirúrgica assume um caráter de procedimento clínico ao considerar os dados biológicos, e ao mesmo tempo, um procedimento de intervenção social ao considerar os dados psicossociais para tomada de decisão.

\subsubsection{Motivos pelos quais casais, homens ou mulheres escolhem a esterilização cirúrgica.}

Segundo MOREIRA e ARAÚJO (2004), as razões da escolha do método contraceptivo estão relacionadas aos valores e modos de vida da população, ao domínio precário de informações para operá-los, assim como, à provisão dos contraceptivos pelo Estado.

CARVALHO e SCHOR (2005) observaram também que as mulheres escolhem um método contraceptivo que Ihes proporcionem uma combinação de vários aspectos: alta eficácia; inócuo à saúde; fácil de usar, aceitável aos seus costumes e que também fosse aceito pelo parceiro sem resistências. A expectativa mais intensamente referida foi de alta eficácia, característica fortemente associada à esterilização cirúrgica.

Para CARVALHO e col. (2004), os motivos para optarem pela esterilização cirúrgica, incluem o não querer ter mais filhos, não poder ter mais filhos, não ter 
condições de criar mais filhos ou já haver alcançado "o número ideal de filhos".

Em estudo realizado por BARBOSA e col. (2009), os motivos informados para decidirem sobre a esterilização foram em $36 \%$ por não querer ter mais filhos, $26 \%$ por indicação médica e o terceiro motivo, em $14,3 \%$ por falta de condições financeiras.

$\mathrm{Na}$ maioria dos discursos, os profissionais entendem que os motivos pelos quais os indivíduos escolhem a esterilização cirúrgica decorrem de um conjunto de fatores como o número de filhos, a questão econômica, os problemas de saúde, conforme relatos a seguir:

$\mathrm{Na}$ maioria das vezes, pela minha experiência, o motivo foi questão econômica. Geralmente as pessoas buscam o planejamento, já, porque não querem mais ter filhos, né, e aí não seria mais um plano de família, ele já não quer filhos. Mas, pela experiência, é por motivos da questão financeira, né, e segundo, é por conta, né, da quantidade de filhos, que já é suficiente, né, e a outra por questões, motivos de saúde (Ártemis, assistente social, 46 anos, trabalha em UBS, católica praticante).

Eu acho que ela tem um número de filhos, quando ela já tem alguma... Acho que quando ela tem alguma idade pra ela poder fazer esse tipo de escolha. Eu acho que a idade tá relacionada com a maturidade do indivíduo. Número de filhos, relação estável com o marido, se ela tem alguma doença de base também, que pode complicar a gravidez. Eu acho que é isso. O desejo do paciente e também parte financeira, eu acho que isso também contribui (Átropos, médica, 41 anos, trabalha em Hospital, católica não praticante).

É eu acho que é ter certeza de que não terão mais filhos, né, devido à condição sócio-econômica. É, basicamente, isso (Dionísio, médico, 50 anos, trabalha no Hospital, plantonista, espírita praticante).

É então, eu acho que é multifacético, né. E assim, eu acho que tem um perfil de usuário, né. Homem... Relacionamentos mais estáveis, mais duradouros, normalmente são: a preocupação com a educação dos filhos, a satisfação com o número da família, o momento de vida, o projeto de vida mesmo, 
"Olha, a gente já teve os filhos, agora a gente quer viajar, agora a gente quer fazer...". Enfim, é uma decisão muito pautada naquele núcleo que está constituído e estável, né. Eventualmente a pressão econômica, né, o desemprego de uma das partes, o investimento que é educar filhos, né, que há um reconhecimento de que é muito cara e que pra oferecer um padrão bom, o número de filhos, às vezes, prejudica a qualidade dessa oferta. Enfim, então eu penso que essas são as decisões mais consolidadas e, via de regra, ela se estabelece num momento cronológico, um pouquinho mais, maior, né, o casal lá pelos vinte e oito, trinta anos por aí, ou daí pra frente, mas sempre com histórico de relações estáveis, eventualmente, até únicos relacionamentos, mas enfim, a realidade, hoje, mostra que os arranjos familiares são muito diferenciados (Atena, assistente Social, 50 anos, trabalha em UBS, católica não praticante).

No discurso de Ares e Aristeu, a falta de conhecimento e o tradicionalismo cultural podem influenciar na escolha do método.

Bom, primeiro... A primeira é a falta de conhecimento, segundo o financeiro, né, e depois, como eu falei, é a própria atitude do paciente. Eu acho que eles pensam mais no lado bom e não pensam no futuro, né. É isso daí. Não pensam, também, nas doenças (Ares, médico, 46 anos, trabalha em UBS, católico praticante).

É a gente tem um grande... Um fator de atraso cultural no Brasil, onde a maioria das mulheres raciocina dessa forma, né, mas, por outro lado, também é um direito válido. Eu acho que, uma vez que ela tem prole constituída, situação definida, matrimonial, eu acho que é totalmente válido.

(Aristeu, médico, 54 anos trabalha em UBS, católico praticante).

Na fala de Afrodite e de Eufrosina a questão da inadequação ou intolerância na utilização de outros métodos anteriores encontra-se presente:

Bom, acho que o principal deles seria a inadequação aos métodos anteriormente utilizados, mas que também a gente observa que quando, às vezes, a paciente traz uma queixa, ou o casal traz uma queixa, e quando a gente conversa, discute com o casal que aquela queixa, poderia eventualmente ser minimizada ou até ser suspensa com o uso adequado, às 
vezes, do mesmo método, ou até a passagem pra outro método reversível, muitas vezes um casal que já vem decidido pra laqueadura, quando se explica, se orienta realmente algumas dúvidas, ou até temores em relação a outros métodos, o casal acaba até optando por um método reversível e não se passando por um risco cirúrgico (Afrodite, médica, 48 anos, trabalha em Hospital, é católica não praticante).

A grande maioria diz que já não quer mais "tá" usando a camisinha, não quer mais praticar o coito interrompido, é o que a grande maioria responde. E que já tem dois, três filhos, às vezes até de casamento anterior, filhos que já estão... , tipo assim, um filho de dezoito anos, e do outro casamento um filho de cinco. Eles também colocam o fator econômico no meio e dizem que não estão querendo mais ter filhos, e que estão conscientes disso. E às vezes acontece de virem com uma segunda ou terceira gravidez, já procurando um método definitivo (Eufrosina, psicóloga, 54 anos, trabalha em UBS, católica praticante).

A ideia da escolha da esterilização por sua alta eficácia, ou seja, pelo método ser considerado com menor índice de falhas, e sem os efeitos colaterais dos outros métodos, conforme constatam CARVALHO e SCHOR (2005), também se encontra presente no discurso de Deméter:

É pelo menor, menor risco que apresenta né, e porque muitas vezes a mulher já se cansa de ficar tomando anticoncepcional, umas tem cefaleia, outras usam o anticoncepcional e preservativo, aí ficam preocupadas se esquecem da pílula, se não esquecem, as que usam injetáveis, algumas engordam, então os efeitos colaterais próprios do anticoncepcional, o uso contínuo, né, e a tranquilidade de um método seguro, que seria, no caso, a laqueadura. Então, na maioria das vezes, quando ela tem decisão, não quer mais constituir uma prole, é um método definitivo que dá maior segurança e tranquilidade, sem grandes efeitos colaterais. (Deméter, médica, 55 anos, casada, trabalha em UBS, católica não praticante).

A questão da comodidade do método, em comparação aos outros, no sentido das usuárias estarem livres de ingerir medicamentos diariamente, de 
desonerar os seus gastos para estes fins, diminuir os cuidados médicos relativos às consultas de controle e seguimento, nem sempre disponíveis com facilidade; estão presentes nos discursos de profissionais abaixo:

Bom, ao meu ver, grande parte das pacientes que escolhem esse método é porque elas querem se livrar de algumas dificuldades de outros métodos anticoncepcionais ou por desvantagem de "tá" todo dia tomando pílula anticoncepcional, pílula anticoncepcional, que tem o problema de esquecer, tá, ou de desvantagem de, de repente, tá usando um DIU ou outro método injetável, hormonal, ou por questões de... Onerado financeiramente, ou mesmo por questões de dificuldades de "tá" se acirrando nas determinadas épocas e datas, então pra ela se torna muito mais prática, menos onerosa, tá, e com uma tranquilidade de tipo, fiz, acabou, esqueci e vou curtir minha vida, tá, porque eu já tenho o número de filhos que eu e meu marido queríamos (Hefesto, médico, 57 anos, plantonista, católico não praticante).

Eu acho que pela facilidade e, talvez, comodidade dela. Talvez por influência dos outros, por achar que por ser definitivo seria melhor, ou pelas dificuldades que ela tem ao serviço de saúde, talvez de fazer o acompanhamento de um DIU, anticoncepcional, preconceitos que existem contra os outros métodos, e também, em alguns casos, apesar de aqui em São Paulo eu achar isso não tão comum como nos outros lugares, é acesso a todos os outros métodos. Então pra elas é mais prático e muito mais cômodo optar por um método que, entre aspas, seria definitivo. (Calíope, médica, 38 anos, casada, trabalha em Hospital, espírita não praticante).

Eles escolhem por motivos financeiros, né, porque diz que não tem condições de criar mais filhos, por comodidade, porque é o que dá menos trabalho, não precisa tomar remédio, não precisa ir ao posto, não precisa ficar fazendo exame, esse é um dos fatores muito grande. Por praticidade, porque eles vão saber que já fez mesmo, então não tem perigo de engravidar de jeito nenhum. Então eu acho que são os maiores motivos que eles acabam buscando (Hera, enfermeira, 42 anos, trabalha em Unidade Básica de Saúde, evangélica praticante). 
Além das vantagens acima descritas, o discurso de Hebe, enfermeira, vai além, ao acrescentar a vantagem do livre exercício da sexualidade, sem se preocupar com uma possível gravidez, principalmente nos casos em que mulheres não tenham um parceiro fixo, muito embora envolvendo muitas vezes, uma prática desprovida de uma proteção contra as doenças sexualmente transmissíveis.

Eu acho que é uma comodidade. Pra mulher que não têm um parceiro fixo, por exemplo, eu acho que é cômodo pra ela. Ela pode ter uma vida sexual bem ativa e não tá se preocupando com a gravidez, sendo que eu acho que ela não deveria tá tanto se preocupando com a gravidez, né. Lógico, é um problema? É. Mas e as doenças sexualmente transmissíveis? A saúde dela como mulher e como ser humano. Eu acho que isso que ela também tá preocupante. Então todos os programas, né, de saúde que falam "Use camisinha", isso é válido pra qualquer pessoa, né. Então quer dizer, o quê que ele tá determinando, isso? É uma gestação? Não. A gestação, de todo um processo, eu acho que é o menos maléfico, né, o maléfico mesmo são as doenças sexualmente transmissíveis. Algumas têm cura, ou seja, faz um tratamento e tem cura, e outras não, têm apenas controle (Hebe, enfermeira, 46 anos, trabalha em UBS, espírita praticante).

\subsubsection{Critérios definidores para as tomadas de decisões pelas equipes.}

Em estudo realizado por VIEIRA e col. (2005), sobre as características de candidatos à esterilização cirúrgica constata-se que 35,8\% mencionaram ter feito o procedimento por estar satisfeito com o número de filhos; $33,7 \%$ por ter problemas de saúde, inclusive muitas cesáreas anteriores; $16,8 \%$ por não querer ter mais filhos, por dificuldades financeiras; $13,7 \%$ por outros motivos como considerar o melhor método, apresentar intolerância a outros métodos e ter filho deficiente.

Pelo discurso de vários profissionais, é o conjunto de condições, que levam em consideração na sua tomada de decisão e não apenas um critério isoladamente: 
É a saúde, é o número de filhos, se é casada, solteira, mora... As condições, em geral, pra mim é um conjunto. (Ártemis, assistente social, 46 anos, trabalha em UBS, católica praticante).

Eu acho que o que pesa mais, como nós somos um hospital aqui de alto e médio risco, é questão saúde, realmente. A gente avalia a usuária como um todo. Não dá pra ver só a questão saúde ou a questão econômica, né, a gente tem que ver a usuária como um todo aí e em cima disso tá decidindo, mas o que vai pesar mesmo é a questão da lei aí, que é a do planejamento, né. (Eumênides, assistente social, 40 anos, trabalha em Hospital, católica praticante).

Tá. Eu acho que a primeira coisa é o número de filhos, tá. A segunda coisa é a estabilidade do casamento, tá, são as coisas que sempre pesam. Em terceiro eu vejo as características clínicas da paciente e em quarto o número de cirurgias, de cesáreas sucessivas (Hefesto, médico, 57 anos, plantonista, católico não praticante).

Pra eu liberar. Eu acho que número de filhos, idade do paciente, relação conjugal estável, comorbidades, né, pacientes que têm outras patologias associadas. São essas (Átropos, médica, 41 anos, trabalha em Hospital, católica não praticante).

Nas falas de Erínias e Eros, a dubiedade de interpretação da lei em relação à idade, por falta de clareza em relação à idade mínima, encerra o centro de uma polêmica presente entre os profissionais quando da tomada de decisão para a realização da esterilização cirúrgica:

O texto, no geral, ele beneficia a usuária, ele protege a usuária. Somente o artigo que fala da idade, ele é polêmico, porque ele não deixa clara a idade mínima pra realização da cirurgia, então ficou uma dúbia interpretação. Ora profissionais entendem que são a partir de vinte e cinco anos só, outros entendem que ele gera essa polêmica, que a idade pode ser menor do que vinte e cinco anos. (Erínias, assistente social, 50 anos, trabalha em Hospital, evangélica não praticante). 
Para mim o que pesa mais é a idade, o número de filhos e patologias associadas. Pra mim é o que mais pesa. Pra mim são itens fundamentais: a idade, pra mim vinte e cinco anos é muito cedo. Eu considero a faixa entre vinte e oito a trinta e cinco anos, ou algo nesse intervalo, eu considero melhor do que vinte e cinco, e algo acima de três filhos eu também considero melhor em relação à prole, do que dois filhos, e patologias que aí realmente passa a ser um critério, que tem uma certa... Tem um peso maior do que os outros dois. Então eu acredito que a indicação médica é fundamental. (Eros, médico, 56 anos, trabalha em UBS, espírita praticante).

O critério para tomada de decisão como a saúde dos filhos para evitar um possível arrependimento por perda dos mesmos por motivos de saúde, também foi apresentada na fala de Eufrosina:

Quantidade de filhos. Nós procuramos, também, saber se os filhos que essas pessoas têm são saudáveis. Saudáveis no sentido assim, de repente essa pessoa pode ter um filho que tem um risco iminente de algum problema de saúde e ela pode até vir a perder esse filho, né, então isso pesa pra gente, também. E a condição econômica também, a gente também tem que ver onde mora, a gente pergunta onde mora se tem casa própria, com quanto vive. Porque nós temos situações que as pessoas têm quatro filhos e vivem com quinhentos reais, quinhentos e dez reais por mês. A gente tenta até ajudar no sentido, assim, "Você não consegue fazer um tipo de trabalho?", a gente até indica pra capacitação profissional, a gente tenta ver esse lado e também ajudar, porque é desumano viver com quinhentos e dez reais, quatro filhos e ainda pagar aluguel. (Eufrosina, psicóloga, 54 anos, trabalha em UBS, católica praticante).

Igualmente Íris, enfermeira, vai além do número de filhos, inclui como critério o grau de convivência da genitora com os filhos, na tomada de decisão, em esterilização cirúrgica:

Eu acho que na nossa equipe pesa mais a questão física. A questão de saúde.

O social, sim. Se ela assume os filhos. Eu acho que esse é o lado que pesa bastante, né. Se ela assume... Por exemplo, às vezes tem gente 
que vem aí e fala "Ah, tem sete filhos", mas ela não assumiu um, tá lá com um ou dois ou não tá com nenhum. Então esse tipo de situação eu acho que acaba pesando mais (íris, enfermeira, 46 anos, trabalha em Hospital, católica praticante).

Em relação ao estado conjugal podemos observar que não há um consenso em relação ao mesmo, como critério determinante para a tomada de decisão por parte da equipe. Apresentando-se antes, em termos controversos.

Assim por um lado, no discurso de Hera, Deméter e Zeus, o estado conjugal não são condições determinantes para uma tomada de decisão:

O que mais pesa pra você dizer sim é a questão da idade. . E em segundo lugar vem a paridade, o número de filhos, e o estado conjugal, implica, mas não é um peso tão grande, não, tá. Porque têm mulheres lá que são... Que acabam procurando sozinha e depois de muita conversa. E assim, não é dentro do primeiro, da primeira reunião e tudo, mas é abordada com um pouco mais de cuidado, mas nós já tivemos liberação pra mulheres que não tem vida conjugal estável, mas que quer fazer (Hera, enfermeira, 42 anos, trabalha em UBS, evangélica praticante).

Em minha opinião é o número de filhos. A condição matrimonial é uma condição que é avaliada também, mas ela perde um pouco em termos de importância quando comparada a questão do tamanho da prole. A idade vem logo a seguir ao número de filhos, mas já também com uma condição, com uma condição um pouco menos importante, eu vou chamar assim, porque como eu disse, é muito pouco comum nós encontrarmos situações de pacientes extremamente jovens que já estão dentro do critério de elegibilidade pelo número de filhos. Então é uma questão... Ela não é necessariamente secundária do ponto de vista de avaliação global da paciente que pretende, da mulher que pretende ser esterilizadas, mas ela é, do ponto de vista populacional, na maioria das vezes, nós temos as pacientes já com idade superior aos vinte e cinco anos, às vezes bem superior a isso, e por isso esse critério tem uma importância um pouco menor. Então, no meu entender, o que mais influencia a indicação ou a contra indicação do procedimento é a prole, o número de filhos vivos que essa paciente apresenta (Zeus, médico, 51 anos, trabalha em hospital, 
não é adepto a nenhuma religião).

Geralmente, o número de filhos e o trabalho, a necessidade de criar bem esses filhos. Então o que mais vale é isso, "Eu tenho um número de filhos suficientes. Eu não quero ter mais filhos. Eu não quero mais usar os outros métodos.", então ela já vem com todos os argumentos e, às vezes, é muito difícil demovê-la. Se, é solteira ou se é casada, pesa no processo de decisão? Pesa, no sentido que é sempre preferível quando você tem uma união estável, né, mas às vezes a mulher não tem uma união estável, já tá no terceiro ou quarto filho, e ela opta por fazer uma laqueadura. Porque ela pode se casar novamente, mas ela tem a certeza que ela não quer um novo filho. E hoje em dia, também, a grande maioria dos casamentos não é uma união, é uma união estável, simplesmente, não é um casamento civil ou religioso, né, então eles ficam e, às vezes se separam e tem um filho com vários parceiros, e chega numa hora que, independente, ela fala "Não quero mais filhos", né (Deméter, médica, 55 anos, trabalha em UBS, católica não praticante).

Por outro lado, contrariamente ao discurso de Hera, Deméter e Zeus, na fala de Ares e Graças o estado conjugal assume importância no critério de tomada de decisão para estes casos:

Eu acho que você pode me chamar de discriminatório, mas eu não gostaria de oferecer... Oferecer laqueadura numa mulher que seja solteira né. Pra mim, no meu caso, do meu ponto de vista é importante. (Ares, médico, 46 anos, trabalha em UBS, católico praticante).

O que mais pesa. Às vezes, o estado civil, né. Tem muito... Pra mim é o estado civil. Têm muitas que são solteiras que querem e que, às vezes, a gente acredita que possa vir a ter outro relacionamento, possa querer, então a gente tenta fazer esse trabalho de conscientização com eles, né. $E$ bastante, vem homens que são solteiros e que não querem mais ter filhos, às vezes tem um ou dois de outro relacionamento e não querem mais ter, mas é isso que me pesa, realmente, fazer essa cirurgia definitiva nessa pessoa. (Graças, psicóloga, 28 anos, trabalha em UBS, católica não praticante). 
A dimensão social dessa prática apresenta-se no discurso de Agalaia, psicóloga, quando menciona a importância de se considerar a própria história de vida de mulheres, homens e casais. Entende assim que além do número de filhos, questão econômica, situação conjugal, considera que não se deve ter em conta apenas a situação momentânea, mas também considerar a história pregressa do casal, assim como, as suas perspectivas de vida futura no processo de decisão:

É eu acho que pra aprovar ou não a esterilização cirúrgica a gente não pode levar, apenas, em consideração a situação do momento. Eu acho que a gente tem que avaliar a história pregressa, né, daquela mulher, do casal, e também fazer com eles uma reflexão a respeito de futuro, né, porque mudanças acontecem o tempo todo na vida e a vida do casal também pode sofrer mudanças no futuro, então eu acho que isso tudo tem que ser discutido, né, com o casal. E muito do que a gente vê hoje é a questão financeira, né, é a questão de cuidados com os filhos, hoje o casal trabalha, né, tanto a mulher quanto o marido, né, o homem, e cuidar de muitos filhos, hoje, vira um impedimento pra cuidar das questões da vida da família.

(Agalaia, psicóloga, 52 anos, trabalha em Hospital, evangélica praticante).

Nos discursos de Afrodite e Calíope, os critérios como o número de filhos, idade, condição econômica, estado conjugal não podem ser avaliados isoladamente e não podem ser dissociados. O critério deve ser a associação de, por exemplo, jovem com cinco filhos, jovem com múltiplas cesáreas, condição sócioeconômica desfavorável com vários filhos e ser solteira:

Na verdade, o que vai... O que pesa, realmente, é a idade e o número de filhos. Na verdade, são duas variáveis aí que não são... Que não dá pra gente dissociar. Porque muitas vezes a gente acaba atendendo mulheres extremamente jovens, mas que tem um número de filhos extremamente elevado e que, realmente, quando a gente conversa e propõe outros métodos a gente acaba percebendo até que elas têm algumas limitações pro uso de outros métodos, e que como é um desejo da paciente com uma prole bastante grande, muitas vezes a gente... Muitas vezes esse caso acaba 
sendo aprovado pra método definitivo, mas assim, a idade, com certeza, seria o fator principal (Afrodite, médica, 48 anos, trabalha em Hospital, católica não praticante).

Eu acho que nenhum fator desses pesa individualmente. Eu acho que uma conjunção deles, então pacientes solteiras, por exemplo, com já o número de filhos que ela considera suficiente e uma má, uma má situação financeira ou não, eu acho que essa teria direito. Por outro lado, às vezes paciente que tem uma união estável ou é casada, mas que você vê que, conversando com ela, essa união é de pouco tempo, que não tem tanta instabilidade, digamos, emocional, talvez eu acho que ela teria... Eu relutasse mais em concordar do que o outro caso. Então eu acho que seria uma conjunção dos fatos, apesar de eu entender que a regulamentação dá direito, inclusive, a pacientes solteiras, que não tem filhos e que desejem. A lei, no meu entendimento, daria esse direito a ela (Calíope, médica, 38 anos, trabalha em Hospital, espirita não praticante).

A complexidade de que se reveste a esterilização cirúrgica como prática nos serviços de saúde pode ser exemplificada em partes das colocações presentes no discurso de Apolo que aponta a questão da autonomia médica no processo de aplicação da lei empregando, inclusive, critérios e protocolos próprios.

Eu acho que é um conjunto de coisas. Eu acho que é como eu te disse, a paciente tem dezenove anos e têm cinco cesáreas, eu acho que ela vai conseguir me convencer com muito mais facilidade do que se ela tivesse trinta e cinco anos com uma cesárea. Então eu acho que é uma somatória desses dados e desse protocolo que eu tinha idealizado né. E esse protocolo, esses dados, eles foram mais baseados assim, empiricamente, na minha avaliação, elas não seguiram um critério científico. Eles foram aquilo do meu dia-a-dia de consultório, então eu imaginei, a idade que eu cortava era mais ou menos trinta e dois anos. Trinta e dois anos até uns anos atrás já era uma idade que a maioria das pessoas já tinha casado e tido dois filhos, três filhos, já tinham mais ou menos a prole constituída. Isso, agora de uns anos pra cá é que ficou mais tarde, mas na época que eu comecei a trabalhar e que eu tinha movimento de parto, bastante, ele era suficiente, 
essa idade de trinta e dois, trinta e três anos (Apolo, médico, 57 anos, plantonista, católico praticante).

Nos discursos acima podemos observar que os critérios para tomada de decisão pelas equipes passam obrigatoriamente pela interpretação da lei e suas controvérsias, estando sujeitas a subjetividades e aos valores pessoais de cada profissional. Os critérios como idade, número de filhos, estado conjugal, condição sócio-econômica, assumem uma estreita intersecção entre a dimensão clínica com a social, daí notadamente no caso dos médicos a decisão centrar-se muito mais em critérios sociais do que propriamente clínicos. Em tela permanece a questão da autonomia do sujeito.

\subsubsection{Sobre concordâncias e divergências no processo de aprovação pelas equipes.}

Nos discursos de Graças e Eufrosina, no âmbito das Unidades Básicas de Saúde, não se observa divergências no processo de aprovação pelas equipes:

Aqui, não. Eu nunca peguei nenhum caso que um discordasse e o outro.. nunca teve (Graças, psicóloga, 28 anos, trabalha em UBS, católica não praticante).

Como a gente participa, desde o começo, junto, a gente já tenta chegar num consenso, a gente não tem muita divergência (Eufrosina, psicóloga, 54 anos, trabalha em UBS, católica praticante).

No discurso de Deméter, médica, as divergências existentes não estão no âmbito da aprovação e sim, na hora da execução do procedimento, ato praticado exclusivamente pela equipe médica, pois retornam às Unidades Básicas de Saúde sem terem realizado o procedimento mesmo sendo aprovadas pela equipe multidisciplinar: 
Entre a equipe não existem grandes divergências, né. Normalmente, as divergências ocorrem quando a paciente vai pro processo final de laqueadura e vasectomia, né; quando ela chega no hospital pra ser realizada, às vezes o colega, como a responsabilidade médica é pessoal e intransferível, ele fica com receio de laquear, por exemplo, uma menina com dezenove, vinte anos, com dois filhos. Então às vezes a gente tem a devolução dessa paciente, né, porque o colega do hospital não concorda em fazer o procedimento (Deméter, médica, 55 anos, trabalha em UBS, católica não praticante).

O fator idade, como geradora de discórdias, está presente nos discursos de Anfitrite e Hera:

Por exemplo, às vezes eu indico uma laqueadura, eu falo pra paciente procurar o planejamento familiar. Ela faz as palestras e a assistente social desencoraja a paciente e fala que não vai dar a carta pra eu assinar porque ela não concorda com a indicação da laqueadura... Pra mim, geralmente as divergências são em relação à idade. (Anfitrite, médica, 39 anos, trabalha em UBS, católica não praticante).

Eu vi poucas divergências. E acabou, assim, as discussões acabaram chegando, mesmo, num consenso. Foram poucas vezes. Geralmente era a idade (Hera, enfermeira, 42 anos, trabalha em UBS, evangélica praticante).

Para Ares, médico, as divergências geralmente são entre os próprios médicos: Então, em relação à aprovação, ou não, da esterilização, existem muitas opiniões diferentes, por exemplo, entre o psicólogo, a assistente social e o médico. Aqui, não. Agora, entre os médicos, sim. Porque alguns defendem que tem que dar cumprimento pra todo mundo, não interessa a idade, laquear quem quer que laqueie, quem quer laquear, né. Isso em termos femininos. Agora, a vasectomia ninguém oferece, né (Ares, médico, 46 anos, trabalha em UBS, católico praticante).

No discurso de Zeus as divergências estão nos casos em que são limítrofes 
perante a lei e o dilema é se o procedimento vai ser benéfico ou não para o interessado:

Existem opiniões diferentes. Eu não sei se elas são muito diferentes porque a equipe do local onde eu trabalho tem certa homogeneidade na maneira de ver uma interessada numa esterilização, ou o interessado na esterilização, mas não é raro a gente encontrar, particularmente quando você tem os limites estabelecidos na própria lei, ou seja, os dois filhos vivos e a idade de vinte e cinco anos, é relativamente comum haver uma diferença de opinião sobre a real vantagem, para o interessado, na realização do procedimento. Então o questionamento, a dúvida mais comum, é justamente nessas situações, em situações limítrofes da própria lei e que você acaba, muitas vezes, imaginando se aquele procedimento não vai ser muito mais prejudicial do que benéfico, tendo em vista que não é raro a gente encontrar pacientes que recorrem à gente no sentido de reverter um processo de... Um procedimento de esterilização a que ela foi submetida. Então essa é a grande... É o grande questionamento, ou seja, as diferenças de opinião. Eu não vejo, eu não tenho, não sinto, pelo menos na equipe com quem eu trabalho e trabalhei, questões religiosas envolvendo esse processo, não sinto grandes questões pessoais, existe uma certa unanimidade com relação às vantagens desse procedimento, tendo em vista uma série de problemas que a nossa população alvo acaba enfrentando. Então, mas essa questão do decidir pela esterilização - lembrando que é considerado um procedimento irreversível - nos limites da própria lei, isso gera, muitas vezes, opiniões conflitantes (Zeus, médico, 51 anos, trabalha em hospital, não é adepto a nenhuma religião).

Para Agalaia, as opiniões diferentes são saudáveis, pois gera um processo de reflexão e é natural que ocorram na medida em que cada profissional tem a sua formação específica, tem a sua história de vida, suas crenças, seus princípios morais. Uma situação de discórdia, conforme relato da mesma, é em relação às mulheres que têm filhos com parceiros diferentes, "um filho com cada pai", no seu entendimento existe uma discriminação nestes casos:

Existe, porque cada profissional ele tem a sua história de vida, ele tem as suas crenças, ele tem as suas convicções, ele tem a sua formação pessoal, 
a sua formação profissional, então sempre tem controvérsias, sempre têm divergências de opiniões, né. E eu acho isso saudável, né, eu acho que quando a gente discute uma situação é importante que tenham opiniões diferentes, pra fazer uma reflexão mesmo.

Então, por exemplo, eu sou da área da psicologia, né, e às vezes aparecem questões em pacientes que têm certa limitação, né, cognitiva, pacientes psiquiátricas, né, que pra família é melhor esterilizar, agora para aquela mulher, para aquela paciente, né, eu acho que a gente tem que tomar um cuidado na hora de avaliar essas situações, porque pras pessoas é assim: "Ah, mas ela não responde pelo que ela faz. Ela pode sair tendo relacionamentos sexuais promíscuos", né. Então eu acho que o risco maior é de ela ter uma DST e não de ela ter um bebê. Eu acho que existem outros métodos que podem ser utilizados, tratamentos que tem que ser tomados. Então essa é uma situação que gera muita controvérsia, né, porque a esterilização cirúrgica numa pessoa incapaz, vamos dizer assim, é uma via de controle que a sociedade faz sobre aquela pessoa. Essa é uma situação. Outra situação que é muito comum, né, são mulheres que não tem uma união estável, que tem vários parceiros, né, e que acabam engravidando, então gera uma discussão também. "Puxa vida, ela já tem um monte de filhos e cada um é de um pai". Então é uma visão preconceituosa com relação à questão daquela mulher. O fato de ela ter vários parceiros, né, acaba criando um certo estigma nessa mulher e a primeira coisa que se diz é "Vamos esterilizar essa mulher". Então existem discussões em torno disso, né, de quem é o poder de definir se aquela mulher vai ser esterilizada ou não, se aquele homem vai ser esterilizado ou não (Agalaia, psicóloga, 52 anos, trabalha em Hospital, evangélica praticante).

\section{A divergência nas equipes por princípios morais também estão presentes no discurso de Ártemis: \\ Olha, na maioria das vezes é favorável. Alguns questionamento, põe... Ouvi falar. O médico não faz, não concorda porque os princípios, né, a formação, Eu percebi que eram mais princípios... morais. Tinha um médico que não aceitava, não... concordava. Aí a gente discutiu com outra médica, se podia assinar ou não (Ártemis, assistente social, 46 anos, trabalha em UBS, católica praticante).}


$\mathrm{Na}$ equipe de médicos plantonistas que são os responsáveis pela execução do procedimento as divergências residem na interpretação e no cumprimento rigoroso do texto da lei, pois eles têm receio em relação à questão do arrependimento e das penalidades que podem advir, sendo que alguns são mais restritivos e outros mais liberais como relata Láquesis e Nikê:

Existem. Nós temos opiniões divergentes dentro da equipe. Assim, eu me considero, dentro da equipe, eu e mais dois somos mais liberais. Os outros dois são um pouco mais restritivos. Eles levam, realmente, o texto da lei ao pé da letra, da forma como eles estão interpretando, entendeu? "Olha, tem que guardar os sessenta dias, sim", entendeu? "Se eu não quiser fazer, eu não sou obrigado a fazer, mesmo que ela tenha a carta". Enfim, são mais restritivos. Eu, realmente, me considero muito mais liberal (Láquesis, médica, 55 anos, plantonista, católica não praticante)

Olha em nível de plantão eu acho que existe divergência sim, e eu acho que existe um medo. O que eu sinto é que existe bastante medo de outros colegas em relação a realização de laqueadura e isso poder reverter num processo, da pessoa se arrepender e aquele ato ter uma consequência pessoal para o médico. Eu acho que é mais nesse sentido que eu vejo a dificuldade na realização do procedimento, e uma diferença de atitude em relação a minha... Eu me sinto mais respaldada. Eu acho que dentro de situações que eu faço uma avaliação, que eu tenho uma permissão do paciente, que eu tenho uma permissão do cônjuge e eu me sinto tranquila com a avaliação, eu não fico tão temerosa. E eu sinto que os meus colegas têm um pouco mais de medo com relação a isso.

É. Assim, já houve situações no plantão de, por exemplo, pacientes de quarenta e três, quarenta e quatro anos, hipertensas, graves, que eu não titubearia em laquear se a paciente quisesse, e que eles ficam "Não, não. É melhor deixar pra outro momento. Acho que agora não.", e eu vejo como uma oportunidade, às vezes, aquela situação, para a esterilização (Nikê, médica, 48 anos, plantonista, espírita praticante).

As divergências entre os profissionais podem gerar conflitos entre o cidadão requerer o seu direito e a opinião dos profissionais serem contrários ao seu 
desejo: Aristeu e Erínias:

Não. Em geral, não [há divergências] Da equipe de saúde, não. O que existe lógico é muito choque entre o casal e a opinião médica, né. Constantemente existe esse choque, né. A paciente quer e a gente não concorda. Não existe conflito entre os profissionais. Não, não tem. É extremamente raro. O que existe é essa falta, essa cultura que eu acho que é muito baixa, ainda, na população em geral, né, a visão de laqueadura é outra, então existe... Isso é frequente, esse conflito, de a paciente não aceitar a decisão médica. Não é a decisão médica, o critério da lei, inclusive, né. O que a gente faz é obedecer ao critério da lei, então... Agora, outra crítica minha que vai é essa... A possibilidade de fazer uma laqueadura numa paciente acima de vinte e cinco anos, sem estar grávida. Porque fazer isso? Essa lei, essa... Esse ponto da lei que eu não, no meu ponto, eu não aceito. Inclusive, eu nunca fiz uma laqueadura numa paciente nessa condição (Aristeu, médico, 54 anos, trabalha em UBS, católico praticante).

Alguns profissionais avaliam o usuário, a paciente, de maneira global. Outros avaliam pelo enfoque médico, quanto à idade, patologia e estabilidade conjugal, sem avaliação do relatório social. São polêmicas as opiniões, em função do desejo da paciente que insiste no cumprimento da lei e quanto à decisão da equipe, muitas vezes contrária ao desejo em cumprimento da lei. Acredito que depois que começaram a reclamar, a se assegurar o respaldo legal, mudaram as opiniões da equipe, ficaram mais controversas, desde que mudou a direção do planejamento familiar. Até então nos respaldávamos pelo protocolo do hospital e a polêmica era menor. Hoje, devido à lei ter uma abertura grande, surge opiniões de profissionais médicos, serviço social e chefe do planejamento (Erínias, assistente social, 50 anos, trabalha em Hospital, evangélica não praticante).

No discurso de Afrodite, o questionamento da não realização no momento do parto previsto na lei é a principal causa de discórdia entre o usuário e a equipe de saúde:

Muitas vezes a paciente, ela chega com uma ideia fixa, né, e até assim, quando a gente faz uma discussão com ela sobre a irreversibilidade do 
método, sobre os riscos cirúrgicos, a única resposta que ela dá é "Mas eu não quero mais engravidar", "Mas eu não quero mais engravidar", então o que a gente tenta sempre falar, e até uma fala que eu faço é "Eu não estou falando pra você engravidar. O que eu estou dizendo é que existem outras formas pra você evitar a gestação, com menos riscos e, praticamente, tão eficazes quanto a laqueadura". Mas quando a paciente se mostra irredutível é solicitado o método definitivo, e esse, e essa solicitação vai passar pela avaliação de outros profissionais que fazem parte da comissão de planejamento familiar. Muitas vezes, quando há uma divergência na aprovação, essa mulher ainda é novamente chamada pra que se refaça essa discussão de que se ela realmente está segura, mas os casos onde há essa divergência não são muitos, e eles acontecem mais numa situação que eu esqueci de falar, que é assim, muitas vezes a mulher, ela está fazendo o pré-natal e durante o pré-natal ela solicita um método definitivo. Então assim, muitas vezes por mais que se esclareça que o método não vai ser realizado no momento do parto, muitas vezes algumas situações de dúvidas, de divergências entre as pacientes, e muitas vezes até mesmo entre os profissionais, mas esses casos não são muitos e a gente observa que cada vez mais, talvez até por um, uma conscientização da equipe e tal, eles têm ocorrido menos (Afrodite, médica, 48 anos, trabalha em Hospital, católica não praticante).

As divergências na interpretação da lei 9263/96 estão inscritas nos discursos de vários profissionais acima, apontando que elas ocorrem entre os próprios profissionais. Nas Unidades Básicas de Saúde o consenso entre os profissionais é maior, enquanto que as divergências ocorrem com maior frequência em âmbito hospitalar, ou seja, no momento de sua execução. Ocorrem divergências ainda entre as equipes de saúde e os usuários, tanto em âmbito da aprovação como na sua execução, transformando-se a aplicação da lei 9263/96 em um grande desafio notadamente para a prática médica. 


\subsubsection{A regulamentação da esterilização cirúrgica contemplando o desejo do casal como um direito: do uso ao abuso.}

O desejo da mulher ou do casal ao ser contemplado com a regulamentação da lei é um dos aspectos considerados relevantes no discurso dos profissionais na medida em que passa a ser considerado como um direito, como se encontra presente em alguns dos discursos dos profissionais a seguir:

Ah, quando a pessoa vem e traz a situação de que... Primeiro o desejo da paciente, né, da pessoa, seja homem ou mulher. Se ela tem esse desejo eu acho que é pra gente pensar junto com a pessoa, né (Íris, enfermeira, 46 anos, trabalha em Hospital, católica praticante).

Ah, por estar regulamentado, né, pelos serviços de saúde terem desenvolvidos políticas de saúde em volta da esterilização, tá? E com isso facilitaram a realização do desejo de quem que quer se submeter (Dionísio, médico, 50 anos, plantonista, espírita praticante).

Ah, muitas vezes as pacientes já chegam solicitando porque realmente tem medo de engravidar novamente ou a não adaptação aos demais métodos que a gente oferece, e eu respeito o querer da paciente. (Anfitrite, médica, 39 anos, trabalha em UBS, católica não praticante).

Eu sou a favor que as pessoas participem do grupo, que saibam o que elas estão fazendo, né, e assim, é um direito que ela tem. Ela pode escolher sim ou não, entendeu? É um direito, então ela... Se ela quer, ela faz. Se ela não quer, ela não faz (Ártemis, assistente social, 46 anos, trabalha em UBS, católica praticante).

A interpretação da lei, principalmente no seu artigo 10, que define como critério para a realização da cirurgia, ter 25 anos ou pelo menos dois filhos vivos, permitiu na fala de profissionais, a escolha do método por jovens em idade muito precoce, daí a preocupação com as implicações do arrependimento na vida futura, se encontra presente na fala de Hermes e Nêmesis: 
Eu acho que abriu um leque muito grande, né, porque a partir de vinte e cinco anos eu acho muito cedo, mas pode ser feita. Porque também tem, tem mulher que ela começa a ter filhos já na adolescência, né, tem mulher com vinte e cinco anos que pode ter o que? Uns quatro filhos ou até um pouco mais. Eu acho que de uma certa forma, sim, facilitou o acesso, mas é aquilo que eu tô falando, que como as pacientes agem por impulso, então eu acho que aumentou mais, né. É, aumentou a procura. Não só a prática, como a procura, né. (Risos).Eu acho que de uma certa forma, foi negativo. Exatamente. Foi por causa disso que são esterilizadas muitos jovens, né. Que tem um futuro pela frente que pode... Eu sempre foco o problema do arrependimento, né (Hermes, médico, 56 anos, trabalha em Hospital, espirita praticante).

É eu acho que antes era muito rigorosa a autorização de laqueadura. Com esta lei facilitou demais, então as pessoas acham que pelo fato de ter vinte e cinco anos e dois filhos já pode escolher a laqueadura, né, então eu acho que ficou... Abriu demais e isso acaba em detrimento de outras pessoas que precisam, né. Facilitou. Por um lado eu acho que foi, porque às vezes a pessoa com vinte e cinco anos tem problemas sérios de saúde e que ela tem o direito, também, de fazer uma laqueadura. Por outro lado, fazer laqueadura numa mulher de vinte e cinco anos corre o risco de ela se arrepender depois. É, tem polêmica quando fala vinte e cinco anos e dois filhos ou... Não, vinte e cinco anos ou com pelo menos dois filhos. Então aí subentende que ela pode ter menos de vinte e cinco anos e também querer fazer laqueadura (Nêmesis, enfermeira, 52 anos, trabalha em Hospital, católica praticante).

Assim como na narrativa de Nêmesis, descrita anteriormente, na fala de Afrodite, médica, podemos observar a preocupação com o uso e abuso na opção pelo método, muitas vezes como de primeira escolha, sem experimentar outros métodos e a sua consequente banalização, sem refletir sobre riscos e implicações, como se fosse um procedimento simples de "limpeza de pele".

Então em algumas situações eu acho que tá perfeitamente bem indicado, mas assim, o que se vê agora, em minha opinião, é uma banalização. Casais muito jovens que nem tentaram, muitas vezes, o uso correto $e$ 
regular de outros métodos, já optando por um método definitivo até porque acaba sendo uma saída mais fácil do que você tem que ter aquela responsabilidade e aquele compromisso do casal pra, realmente, fazer 0 planejamento familiar.

Por um lado houve um grande benefício, porque o principal objetivo da lei foi reduzir o número de cesáreas somente pra se realizar laqueaduras tubárias, né. Então assim, por este lado eu acredito que foi um ganho. Por outro lado, como eu já disse, o que a gente observa são casais extremamente jovens já optando por um método definitivo, muitas vezes num relacionamento conjugal inicial ou com uma série de conflitos, e assim, sem ter realmente sido orientados, ou sem ter tentado fazer o uso de alguns outros métodos reversíveis. Muitas vezes a gente até brinca, né, no ambulatório, onde eu atendo junto com os residentes, às vezes a paciente vem achando que ela vai ser submetida a um procedimento cirúrgico e que o risco vai ser o mesmo de se estar fazendo uma limpeza de pele, por exemplo, um risco inexistente. Quando a gente conversa sobre os prós e os contras do método cirúrgico e também de se tratar de um método definitivo, muitas vezes a paciente comenta que ela não havia sido adequadamente orientada, e que ela não havia pensado nessas possibilidades de risco ou de falha.

Por outro lado, é o que eu também já citei essa questão da laqueadura ser um método escolhido, às vezes, como uma primeira escolha do casal. Um casal que nunca usou método nenhum acaba tendo um, dois filhos, e de repente acaba sendo o método de escolha porque as duas gestações anteriores não foram planejadas (Afrodite, médica, 48 anos, trabalha em Hospital, católica não praticante).

A constatação de mudanças que ocorrem em nossa sociedade contemporânea, na qual se observa relacionamentos conjugais mais duradouros, mas igualmente e com grande frequência troca de parceiros conjugais, fato este também observado no estudo OLIVEIRA (1996) sobre a família brasileira no limiar do ano 2000, tal fato aliado à facilidade da escolha e acesso à esterilização cirúrgica a partir da regulamentação da lei 9263/96 e a preocupação com um possível arrependimento futuro apresenta-se como questão importante de saúde pública tendo em vista observar-se uma demanda crescente para reversão, que se 
encontra presente no discurso de Eros:

Eu, assim, na minha experiência clínica eu vejo que os pacientes, infelizmente, são muito mal orientados. A gente sempre encaminha para 0 planejamento familiar, mas muitas vezes, apesar dos planejamentos feitos nas Unidades Básicas, nós vemos casais muito mal informados, né, e a gente vê, nos casos de ambulatórios de infertilidade, os retornos de pacientes que comumente vêm arrependidos do método, o que reforçam a nossa posição contra o método definitivo em pacientes jovens. Por isso que eu... Eu acredito que se... Eu não sei quem fez essa lei e que estabeleceu essa idade de vinte e cinco anos que eu nunca concordei. Sempre, sempre tivemos protocolos próprios aqui na casa maternal em que colocávamos trinta e cinco anos e pacientes já com prole constituída, considerando prole constituída de quatro a cinco filhos, e não de dois filhos. Então nós sempre tivemos um protocolo particular e nunca nos deixamos levar por esse protocolo feito oficialmente, que eu acho que não atende aos interesses, assim, da... Aos verdadeiros interesses da sociedade, eu digo. Eu digo com toda a conviç̧ão. E tá aí o ambulatório, aqui no nosso hospital tem aqui o ambulatório de infertilidade que não nos deixa mentir, que mostra uma grande quantidade de pacientes requisitando reanastomoses tubárias, pacientes que precocemente fizeram o método definitivo, que consideravam naquele momento como algo muito bem pensado, como algo muito bem planejado, e que depois, muitas vezes, não, não muito raramente, em poucos anos, né, de cirurgia a paciente já tenta uma reanastomose. Hoje em dia os casamentos não são como antigamente, né, em que os casamentos eram muito bem formados. Pra um casal se separar, devido à cultura de se estabelecer um relacionamento mais duradouro durante, né, durante a vida, então para um casal se separar era muito mais raro. Hoje em dia, infelizmente, os casamentos, eles têm uma ruptura muito precoce, então a gente vê casais constantemente trocando de parceiros, né, e muitas vezes esses outros parceiros, mesmo que a mulher já tenha filhos e até uma prole constituída, mas quando ela se associa com outro parceiro que ainda não tem um filho biológico, esse parceiro, a gente, a gente, na nossa experiência clínica, a gente percebe claramente que ele não se contenta em ter filhos dos outros, ele quer sempre um filho biológico. São justamente nesses casos em que as pacientes tentam a reanastomose. A grande maioria delas estão nesses casos, além de que em pacientes jovens, além de não ter 
muitas vezes uma estabilidade conjugal plena, muitas vezes existe 0 infortúnio de ela perder o parceiro, né, e ter um outro relacionamento, e mais uma vez o mesmo problema: o outro parceiro não tem filho biológico e essa mulher vai ser submetida a uma reanastomose para tentar fornecer a esse parceiro o filho biológico. Então por isso, avaliando esses casos, avaliando casos também de pacientes que, muito mal orientadas em relação aos efeitos colaterais da esterilização cirúrgica em que muitas passam a ter algias pélvicas, passam a ter alterações de ciclos menstruais e passam a ter, então, queixas crônicas, muitas vezes por laqueaduras muito mal indicadas. Então eu acho que deve haver, eu acho que realmente é muito louvável que seja feito um estudo mais profundo e que isso chegue, inclusive, em nível dos legisladores, para que haja uma lei com estudos mais consistentes, mais profundos, que atenda realmente aos interesses das pacientes e da sociedade brasileira (Eros, médico, 56 anos, trabalha em UBS, espírita praticante).

O discurso de Eros aponta questões que estão no centro da problemática que são de diferentes ordens:

O planejamento familiar nas Unidades Básicas de Saúde, não orienta adequadamente para a disponibilidade de opção para os diversos métodos contraceptivos.

- $\quad$ Aponta o cerne da controvérsia que é o critério da idade e permite observar a própria polêmica trazida à época da aprovação da lei quando o próprio Presidente da República vetou o artigo 10 e que foi aprovada pelo Congresso Nacional.

- $\quad$ A idade como cerne da polêmica levando à procura de reversão por arrependimento.

- $\quad$ A prática profissional distante do que se poderia considerar como neutra e objetiva, uma vez que, sua prática depende da visão de mundo, da ideologia e da decisão do próprio profissional que a executa.

- $\quad$ O problema como dilema profissional.

- $\quad$ O duplo efeito social e biológico 
- Destaca ainda a relevância de estudos de avaliação da aplicação da lei.

O discurso de Ares, médico, permite ampliar a discussão trazida por Eros, na medida em que, a lei depende de quem a interpreta, notadamente no caso de casal muito jovem, ou seja, a própria questão do direito em termos controversos, gera um conflito de diferentes naturezas, entre o direito do usuário em requerer 0 procedimento e o direito ético do médico em não executar apesar de previsto em lei; vale destacar ainda que para Ares, em casos de pacientes muitos jovens, o mesmo é favorável apenas quando esta for portadora de HIV, fato este observado também na literatura, que relata haver uma cultura médica favorável à esterilização nesses casos, com uma prática inclusive não prevista em lei que é a esterilização no parto e no pós-parto imediato (FARIAS e col., 2008).

É um direito da mulher ou do casal, né, de escolher. É um direito da mulher, do casal, escolher um método contraceptivo, só que eu gostaria muito que a lei tivesse uma idade mínima pra se fazer a laqueadura. Por exemplo, se você abrir mão da idade, né, e, talvez, até outros parâmetros, a lei dá margem pra muita discussão, né, no caso de uma paciente jovem. No caso de algumas doenças infecto-contagiosas do tipo HIV é de se pensar se a laqueadura é, mesmo, o melhor procedimento. No caso de laqueadura de pacientes com HIV a gente sabe que não pode amamentar, ou teoricamente, de fazer qualquer coisa. Eu acho que eu sou a favor da laqueadura na mulher jovem com HIV, agora nos outros casos é de se pensar. Não é fazer a laqueadura assim, sem discutir o caso, o problema, só que eu gostaria que ele tivesse, pelo menos, uma idade mínima, né.

Eu acho que a lei depende de quem interpreta, né, de quem lê e como é que se julga depois, né. A lei é boa pra proteção da mulher se ela exigir o direito, né, só que nós também temos o direito de não fazer, né, diante do nosso código de ética médica. A lei, ela tá... Olha, a polêmica... A polêmica, em si, é toda a lei, né. Em homens e mulheres com capacidade civil plena e maiores de vinte e cinco anos de idade ou pelo menos dois filhos vivos, desde que observado o prazo mínimo de sessenta dias entre a manifestação da vontade e o ato cirúrgico, né. Então esse ou também é que dá muita interpretação. Esse ou, quer dizer, se a paciente tiver vinte e cinco anos e 
não tiver filhos também pode exigir a laqueadura (Ares, médico, 46 anos, trabalha em UBS, católico praticante).

Como pudemos observar na fala dos profissionais, encontra-se presente a preocupação com a demanda abusiva da esterilização cirúrgica em casais jovens, muita vezes tratada como um procedimento banal, baseada no simples desejo do casal, que elege o método como de primeira escolha, sem a devida reflexão pelas possíveis consequências futuras, propiciada pela ampla abertura contida na lei 9263/96, sujeita a diferentes interpretações que possibilitam tal prática em idade precoce, gerando maiores possibilidades de arrependimento. 


\subsection{Das ambiguidades e das controvérsias da lei 9263/96 aos dilemas nas decisões.}

Tendo em vista, conforme pudemos observar; que não existe consenso em relação à interpretação do texto da lei 9263/96 e que alguns aspectos a questão da interpretação apresenta dilemas de profissionais nos processos de decisão pela aprovação da esterilização em mulheres, homens ou casais que demandam esse procedimento, o objetivo da apresentação e discussão, a seguir, é a de identificar as várias facetas dessas ambiguidades e controvérsias a partir dos discursos dos diferentes profissionais entrevistados. Para tanto, utilizamos como recurso metodológico a estratégia de simulação de casos clínicos relacionados ao texto da lei para interpretação e decisão peloprocedimento.

\subsubsection{Sobre a esterilização em casal jovem com idade inferior a 25 anos e dois filhos vivos, neste caso mulher com 21 anos, com relacionamento conjugal estável.}

Diante da emergência de controvérsias na interpretação e dilemas na aprovação e aplicação da lei 9263/96, já relatados pelos profissionais de saúde, pudemos observar que a mesma se dá principalmente em relação ao artigo 10 Inciso I que diz: Somente é permitida a esterilização voluntária nas seguintes situações, em homens e mulheres com capacidade civil plena e maiores de vinte e cinco anos de idade ou, pelo menos, com dois filhos vivos, desde que observado o prazo mínimo de sessenta dias entre a manifestação da vontade e o ato cirúrgico, período no qual será propiciado à pessoa interessada acesso a serviço de regulação da fecundidade, incluindo aconselhamento por equipe multidisciplinar, visando desencorajar a esterilização precoce. Tendo em vista identificar os vários aspectos que emergem em relação a essas ambiguidades e controvérsias fizemos uma simulação de um caso clinico com um casal jovem que optou pela esterilização cirúrgica, como abaixo apresentado para apreender qual a avaliação 
dos profissionais de saúde sobre o referido caso diante da lei e sua possível conduta:

Se o $\mathrm{Sr}\left({ }^{a}\right)$ estivesse escalado para opinar na seguinte situação : Homem ou Mulher jovem, 21 anos de idade, com dois filhos vivos, com vida conjugal há 5 anos, que deseja contracepção definitiva através de laqueadura tubária ou vasectomia. O que o $\mathrm{Sr}(\stackrel{\text { a }}{)}$ tem a dizer sobre as seguintes questões:

a- acha que a lei garante claramente o direito a esterilização cirúrgica ?

b- $\mathrm{O} s r(\stackrel{a}{)})$.aprovaria e executaria o procedimento?

Para muitos profissionais, em sua interpretação do texto da lei, a mesma não garante o direito á esterilização por entender que a idade mínima é de 25 anos e, portanto, não aprovariam ou executariam o procedimento, conforme narrativas a seguir:

Não, a lei não garante. A lei...Então, a lei é clara por que a lei é de vinte e cinco anos, no mínimo dois filhos. Têm dois filhos, mas a lei é de vinte e cinco anos, no mínimo vinte e cinco anos, tá. Não faria. Não executaria. Primeiro porque, pra mim, vinte e um anos de idade, tá, é um casal muito jovem. Tudo bem que eles têm vida conjugal há cinco anos, tá, porém, ainda é uma idade muito, muito precoce pra você fazer uma esterilização definitiva no casal. Eu não sou concorde com isso. Eu, de repente tudo bem se eles sabem que o número de filhos que eles têm é só esse. Agora, você me deu muito poucas coisas aqui pra mim decidir, né. Nossa, eu faria todos os outros métodos anticoncepcionais com ela, incutiria, orientaria da melhor forma possível pra ela, pra ela usar algum outro método anticoncepcional, menos a cirurgia de laqueadura ou a vasectomia no homem. Eu não encaminharia para outro profissional (Hefesto, médico, 57 anos, plantonista, católico não praticante).

Ela não faria como eu já havia dito anteriormente, por aquele detalhe da idade. Então, na minha visão, esse casal não entraria neste processo de esterilização, de contracepção definitiva. Pela lei, não, informando que por causa da idade não seria permitido, já... Como eu já havia dito pra você, que já retornaram pra nós, casos com menos de vinte e cinco anos já retornaram. E se fosse, também, pra mim tá orientando, né, eu, como profissional, eu também orientaria a aguardar mais um pouco. Porque eu 
acho que são casais jovens, com vinte e um anos, tem apenas dois filhos, né, e poderia tá guardando mais um pouco pra ver se vem algum terceiro, e "taria" indicando outro método contraceptivo de longo prazo, né, que demore mais pra tá evitando um terceiro. Como profissional, não autorizaria esse procedimento (Graças, psicóloga, 28 anos, trabalha em UBS, católica não praticante).

Olha, no caso... Nesse caso, vinte e um anos não é a idade. Então tá contra a lei, ela não garante esse direito. Eu não aprovaria. Por conta da lei. Porque está contrário à lei e aqui não diz, aqui só se fala de um desejo, então eles são jovens e existem outros métodos, né. Então muitas vezes o quê que é? A pessoa até chega, realmente, com vinte anos e nesse mesmo caso. Só que é assim, cabe à equipe tá informando outros métodos, e isso é importante, esse é um trabalho que a UBS deveria estar fazendo, né. Apesar de que, pra chegar aqui com vinte e um anos sem problema nenhum, talvez não chegue pra nós, mas nas UBS com certeza chega. Mas aí tem que ter todo um trabalho de uma equipe „multi", é um trabalho informativo, educativo pra poderem conhecer outros métodos, né, que não seja uma coisa definitiva. Nesse caso, nem por condições clínicas, pelo menos não fala aqui, é só um desejo mesmo (Tália, psicóloga, 46 anos, trabalha em Hospital, católica praticante).

Vinte e um anos, não. A lei não garante. A lei, que eu saiba, é vinte e cinco anos, né.

Não, eu acho que não garante. Na minha interpretação é vinte e cinco anos. com vinte e um anos de idade... Quer dizer, vinte e cinco anos, né. Acima de vinte e cinco anos e dois filhos. Em hipótese nenhuma executaria o procedimento. É, porque a lei... Independente da lei existe o meu critério como médico, entendeu? Então na pessoa de vinte e cinco anos de idade eu não faço laqueadura, mesmo, que a lei diga. Mesmo porque tem vários aspectos da lei que eu não concordo. Eu, particularmente, não faria. Eu digo a você... Eu tô falando assim, uma paciente minha uma paciente que eu tô orientando, tudo, eu orientaria a não fazer, entendeu? Agora, o que a gente vê aqui é muito assim, é paciente que vem pelo planejamento e eu sou obrigado (Aristeu, médico, 54 anos, trabalha em UBS, católico praticante). 
Não. Pela essa lei, não. Principalmente porque ela não tem patologia nenhuma e tem abaixo de vinte e cinco anos e só dois filhos. Ela garante a partir dos vinte e cinco anos. Vinte e cinco anos é a idade mínima. Não, eu não faria o procedimento. A não ser que ela tivesse alguma patologia que ela tivesse risco de vida numa próxima gravidez. Não executaria. Nem pagando (Hermes, médico, 56 anos, trabalha em Hospital, espirita praticante).

Pra esse casal de vinte e um anos, não, pela restrição de idade, né. Apesar de terem dois filhos vivos, a rigor a lei não permitiria com essa idade. No texto da lei não garante claramente o direito à esterilização cirúrgica? Não com essa idade. A partir dos vinte e cinco, e que eu ainda acho precoce, né. Não executaria o procedimento, por causa da idade. Você encaminharia pra outro profissional para executar o procedimento? Não. Eu tentaria convencêlos a mudar o método. Colocar um DIU ou fazer algo que daria um tempo de tranquilidade em relação à escolha, mas que teria uma reversibilidade (Nikê, médica, 48 anos, plantonista, espírita praticante).

Não. Eu acho que não tá na idade que a lei recomenda né. A lei recomenda que seja com vinte e cinco anos. Eu acho que aqui nesse caso específico, eu acho que o fator mais importante é o fato do cara ser muito jovem, então vinte e um anos eu não faria, essa aqui eu não faria. Eu acho que... Se a lei garante claramente o direito à esterilização cirúrgica? Eu acho que não. Não, porque um dos itens, que é o da idade, ele não atinge. "Ou" pelo menos com dois filhos vivos. Olha Sérgio, eu, pessoalmente, discordo. Eu acho que a idade tem um peso muito importante nesse tipo de coisa. Quer dizer, eu acho que não é um parâmetro que você pode filtrar sozinho, a idade. Porque se fosse quarenta e um anos e um filho eu acho que a idade pesaria mais, Mas com vinte e um anos? Eu acho que se pra fugir de um dos parâmetros da lei, eu acho que esse é o mais complicado, porque a pessoa não tem maturidade pra... Eu acho, pra uma coisa definitiva. Isso aqui só vai aumentar o risco de o Estado ter que pagar pra ela, depois, a recanalização. Não encaminharia para outro profissional. Eu responderia que eu não faria e se a pessoa quiser, por iniciativa própria, procurar outro, ela tem o direito, mas eu não faria (Apolo, médico, 57 anos, plantonista, católico praticante). 
Se na fala dos vários profissionais a lei não apresenta dúvidas de interpretação, nos discursos de Nêmesis, enfermeira; Eufrosina, psicóloga e de Erínias, assistente social, há reconhecimento de uma controvérsia no texto da lei em relação ao caso da idade mínima para a esterilização cirúrgica. Essas mesmas controvérsias encontram-se presentes igualmente na literatura de estudiosos do assunto como VIEIRA e col.(2005); BARBOSA e col.(2009); MARCOLINO (2004); BARBOSA e KNAUTH (2003) para as quais a idade mínima para esterilização cirúrgica é de 25 anos; outros autores como ROSAS (2001), HENTZ (2004) e OSIS e col.(2009) interpretam o parágrafo como sendo 25 anos ou pelos menos dois filhos vivos, portanto, sem especificação de idade mínima.

Não. Porque a... É aquele item, né, que a lei fala vinte e cinco anos, só que fala ou pelo menos dois filhos vivos, né. Se o casal ler essa lei ele vai achar que ele tem direito, mas, em minha opinião não. A lei não garante claramente o direito (Nêmesis, enfermeira, 52 anos, trabalha em Hospital, católica praticante).

Não, porque ela já não atende a idade, né. Vinte e um anos. É vinte e um anos? Aí já é uma situação complicada, pela própria idade da pessoa. Eu, como profissional, pensaria assim: vinte e um anos, dentro da concepção do psicólogo, é um adolescente ainda então ela vai poder mudar de ideia muitas vezes durante a vida dela. Será que esse método seria o adequado pra ela? $E$ se os anos passassem e ela pode... Há "n" possibilidades, ela pode deixar, separar do marido, ela pode ficar viúva, ela pode querer estar sozinha e depois com trinta, trinta e cinco, quarenta anos querer alguém, esse alguém pode falar "Eu quero uma mulher que me dê filhos", e ela não vai poder dar mais. Eu acho assim, pra mim, em minha opinião como psicóloga, é uma adolescente e a cabeça dela vai mudar muito. É até difícil, com vinte e um anos, ela ser uma mãe estabilizada pra cuidar dos filhos que ela tem.

Não, a lei não garante claramente. Não. Eu não aprovaria. Eu não assinaria. Dentro de um grupo, eu não assinaria. E sei, até, que as pessoas que participam comigo também não assinariam. Porque a gente vê, pela prática, o outro lado, esquecendo que é uma pessoa que quer a esterilização. Essa pessoa de vinte e um anos, ela é muito imatura, mesmo ela "tando" há cinco 
anos, já, num relacionamento conjugal. Ela está com essa pessoa desde os dezesseis anos de idade. Aí eu já vou pesquisar. Ela ficou de livre e espontânea vontade com essa pessoa, aos dezesseis anos de idade, ou foi porque ela, a família fez eles ficarem? Como que foi? Eu acho que com vinte e um anos muita coisa vai mudar. Eu não assinaria. (Eufrosina, psicóloga, 54 anos, trabalha em UBS, católica praticante).

A lei não garante a esterilização cirúrgica, no sentido de que ela tem uma discussão polêmica quanto à idade. Ela não coloca, não menciona a idade mínima para a realização do processo cirúrgico. Gera um questionamento sério entre os profissionais e uma cobrança do usuário que interpreta a lei da forma dele sem ter uma avaliação global da situação do casal. Não. Vinte e um anos, jamais. Paciente jovem, mesmo com dois filhos, jamais faria. Assim, teria que ser estimulado a um método reversível, retornar ao planejamento, amadurecer a ideia e retornar aos serviços até... Usando o método reversível, até ele ter uma ideia, uma idade, no caso, uma idade mais amadurecida pra poder ter uma decisão tão séria quanto é a da laqueadura ou vasectomia (Erínias, assistente social, 50 anos, trabalha em Hospital, evangélica não praticante).

Por outro lado nos discursos de outros profissionais a interpretação da lei é a de que ela garante o direito à esterilização cirúrgica nesse caso e executariam o procedimento por entender que está prevista nalei:

Temo direito. No texto da lei, sim, na minha interpretação.

Faria o procedimento porque, tá dentro da lei. (Anfitrite, médica, 39 anos, trabalha em UBS, católica não praticante).

Sim, acho. É claro, não tá, mas eu acho que pela lei ela tem direito, uma vez que fala que homens e mulheres com capacidade civil plena e maiores de vinte e cinco anos. Sim, executaria o procedimento. Mesmo sendo um paciente com vinte e um anos? Mesmo sendo. Mesmo sendo. Porque tem o amparo legal (Dionísio, médico, 50 anos, plantonista, espírita praticante).

No discurso de Deméter, Agalaia e Afrodite há reconhecimento do direito, 
mas somente aprovariam ou executariam o procedimento após certificar-se da segurança, maturidade da decisão, ou irredutibilidade por parte da jovem, ou jovem. Ao colocarem tais condições apontam para as diferentes ordens de questões de tal procedimento envolve, extrapolando a própria esfera de problema estritamente clínico, caracterizando esse procedimento como importante questão social, em seu sentido amplo.

Sim. Acho que tem. Tem, sim. Executaria. Hummm. Tendo toda... Ela tendo passado com a assistente social, com a psicóloga, tendo tido acesso a todos os outros métodos. Tendo em mãos a segurança da decisão da usuária, executaria o procedimento (Calíope, médica, 38 anos, trabalha em Hospital, espírita não praticante).

Eu acho que a lei garante claramente o direito a esterilização. O que eu acho é que, assim, tem que ser um processo mais intensivo ainda de desistência, mas se for um casal extremamente bem resolvido, consciente, sabendo do que tá fazendo, eu acho que tá dentro da lei e eles têm o direito. Faria. Realizaria, depois de vários processos de convencimento a não fazer, mas se eles optarem por isso, sim (Deméter, médica, 55 anos, trabalha em UBS, católica não praticante).

Olha, como a lei fala vinte e cinco anos ou dois filhos, né, eu acredito que nesse caso ela poderia, sim, apesar da idade dela, vinte e um anos, né, e o tempo de vida conjugal de cinco anos ser um tempo relativamente pequeno, né, ela poderia ser incluída na lei, sim. Eu acho que ela teria direito a fazer a laqueadura, ou ele a vasectomia. É... Eu precisaria conversar bastante com os dois, primeiro. Primeiro porque eles são jovens, né. Eu iria avaliar se eles já fizeram o uso de outros métodos. Eu acho que eu teria que escutar um pouco a história. Supondo que a gente tem uma situação que eles são irredutíveis em sua opinião. Eles já têm uma segurança na decisão, ele não quer se utilizar de outros métodos contraceptivos, né, e são, realmente, categóricos nessa situação. Olha, se eu tivesse escutado e visto que era uma decisão do casal, embora a idade jovem e vida conjugal curta, eu acho que eu aprovaria, sim (Agalaia, psicóloga, 52 anos, trabalha em Hospital, evangélica praticante). 
Eu acho que a lei garante claramente, sim. Eu acho que tá escrito isso na lei. Esse é um dos casos que mais gera as discussões, por ser um casal extremamente jovem e apenas com dois filhos. Eu acho que é difícil a gente poder dizer que aprovaria ou não sem nenhuma... Sem nenhuma outra complementação. Por exemplo, se já tentaram...eu tentaria, inicialmente. Embora está claro na lei, eu tentaria conversar com esse casal e propor o uso de um método não definitivo. Em sendo... Se eles já tivessem sido abordados, se eles tivessem sido adequadamente esclarecidos e realmente se tornassem irredutíveis, eu realizaria, mas com muito pesar, porque eu não acho ser uma idade adequada para um método definitivo (Afrodite, médica, 48 anos, trabalha em Hospital, católica não praticante).

Se a questão da ambiguidade do texto da lei se evidencia pelas diferentes leituras de profissionais antes relatados, o direito reconhecido em outros discursos ganho foro de controvérsia pela não concordância de profissionais na execução da lei, em casos de esterilização cirúrgica, considerados precoces em jovens, conforme discursos a seguir:

A lei garante só que eu não faria. Eu não faria pela idade. Eu já falei, eu sou contra esse nível de idade. É um casal que tem grande chance de, de voltar, de arrependimento. Eu nunca, na minha vida profissional, esterilizei ninguém com vinte e um anos. Não, eu deixo a paciente escolher. Porque quando eu tô encaminhando é a mesma coisa, eu sou conivente. Eu não encaminho para outro profissional (Eros, médico, 56 anos, trabalha em UBS, espírita praticante).

A lei garante. Eu acho que eu seria resistente em assinar um termo de autorização se não explicar, também, os outros meios contraceptivos, né. Eu falei, a maioria das pessoas chegam... É, principalmente na nossa sociedade, que é muito machista, joga tudo pra mulher, é comprimido, injeção ou laqueadura. Então eu tenho que citar as consequências, as vantagens e desvantagens, né, principalmente numa paciente de vinte e um anos. Mesmo se esse casal se mostrasse seguro, Eu acho que não. Não, mesmo. Por mais que o paciente seja esclarecido, e tenha certeza. Porque vinte e um anos, vinte e cinco anos é uma idade muito precoce (Ares, médico, 46 anos, trabalha em UBS, católico praticante). 
Eu acho que garante porque ela tem menos de vinte e cinco anos, mas ela tem dois filhos vivos. Como a lei é ou, vinte e cinco anos ou dois filhos vivos, então por lei ela tá garantida, né. Eu deixaria ela à vontade pra procurar outro profissional, mas talvez orientasse que a idade, relação de cinco anos, às vezes a gente percebe que daqui a dez anos a vida muda, muita coisa pode acontecer, então eu tentaria um outro método pra ela. Eu não executaria o procedimento (Átropos, médica, 41 anos, trabalha em Hospital, católica não praticante).

A lei fala vinte e cinco anos ou dois filhos. Quer dizer, tem dois filhos. A lei garante. Tá estabelecido o número de filhos vivos, mínimo, que é igual a dois, e como a lei exige isso ou uma idade superior a vinte e cinco anos, eu não tenho dúvida que esse é um indivíduo que tem, perante a lei 9263, o direito de ser submetido à esterilização. Não, eu não realizaria. Eu considero essa uma faixa etária extremamente baixa, e tendo em vista a possibilidade que eu tenho de me recusar a realizar um procedimento, fora, é óbvio, de uma situação de urgência ou emergência, eu acredito que essa é uma situação em que eu deveria tentar motivar essa pessoa a utilizar algum método reversível por, pelo menos, alguns anos, pra que não haja qualquer tipo de dúvida com relação à realização do procedimento, então eu não realizaria o procedimento. (Zeus, médico, 51 anos, trabalha em hospital, não é adepto a nenhuma religião).

Garante, sim, quando a gente passa naquele... Esse impasse que eu já falei, ou pelo menos dois filhos vivos. Nesse caso eles têm dois filhos vivos, né, tem uma estabilidade conjugal de cinco anos, então dentro da lei eu acredito que é um respaldo. Eu entendo assim.. Embora seja garantido por lei eu acho que eu orientaria eles a aguardarem um pouco mais, porque vinte e um anos a gente ainda não tem maturidade pra muita coisa. Eu não aprovaria a realização do procedimento. (Hera, enfermeira, 42 anos, trabalha em UBS, evangélica praticante).

Então, a lei, ela garante, né, mas uma pessoa de... Se a gente for pensar ali... Pensar no histórico desse casal de vinte e um anos, dois filhos vivos e cinco anos de união aqui, né, é bem precoce. Porque vinte e um anos 
praticamente ainda está iniciando a vida. A gente tem que tá refletindo. Se o casal, né, chegou pra gente com esses dois filhos e esse histórico de fazer a esterilização, porque não, a gente não pensar em orientar esse casal, né, direitinho, né, colocar eles no grupo de reflexão e oferecer outros tipos de métodos, né? Vinte e um anos, muita coisa pode mudar nesse casamento. Então assim, quando a gente faz as nossas entrevistas aqui no dia-a-dia e a gente encontra uma situação dessas, a gente chama os dois... A gente também tem a dificuldade de vir o casal, né, vem sempre a mulher. Então a gente pede pro casal vir, a gente orienta e a gente coloca tudo o que pode tá acontecendo aí. Então assim, não é só a questão da esterilização. Então hoje esse casal, ele tá estável aí, mas amanhã esse casamento já não pode mais existir, né, ou algum desses filhos aí vir a falecer e esse casal vai querer ter outro filho. Então por que usar um método tão definitivo? Porque ser tão... Mesmo que esse casal, ele traga essa ideia "Não, eu quero realmente fazer", mas porque um método tão definitivo, sendo que eles têm uma idade bem jovem ainda. Porque não oferecer outros métodos aí? Não aprovaria. Não, porque existe o caso do arrependimento, futuramente, né. Com certeza, não aprovaria (Eumênides, assistente social, 40 anos, trabalha em Hospital, católica praticante).

Hebe e Láquesis reconhecem que o texto da lei é dúbio, mas em suas interpretações a lei garante a esterilização, entretanto, também não aprovariam a execução do procedimento, o que mais uma vez sustenta a hipótese de que a lei apresenta não somente ambiguidades, mas igualmente controvérsias notadamente em relação à idade mínima prevista:

Tá. Bom, a lei é meio dúbia. Por exemplo, ela fala que idade mínima são vinte e cinco anos. No caso, esse casal tem vinte e um anos, mas eles têm dois filhos vivos. O que o faria? Eu jogaria esse processo, né, esse caso, pra equipe multidisciplinar. Então aí a gente precisaria avaliar as condições sócioeconômicas deste casal e a maturidade, ou seja, aí o psicólogo entraria em ação pra saber até que ponto eles estão decididos nisso, né, e qual a maturidade a respeito. Aprovaria se ele tivesse convicto disso. Mesmo que esteja dúbio no texto da lei aprovaria (Hebe, enfermeira, 46 anos, trabalha em UBS, espírita praticante). 
Não, a lei é dúbia. É dúbia, exatamente porque é aquilo que eu coloquei, o e/ou provoca essa dubiedade. Não é claro. Eu tenho dúvida. você executaria o procedimento? Executaria. Se não houvesse... Se não houvesse essa... Eu, do ponto de vista pessoal... Minha opinião... Eu não executaria.

(Láquesis, médica, 55 anos, plantonista, católica não praticante).

Em termos dos direitos adquiridos pelos jovens à esterilização cirúrgica, as falas de Íris e Atena permitem sintetizar em que termos a ambiguidade e a controvérsia na lei se apresentam e são tratadas por profissionais de saúde:

A lei garante. Diante de uma segurança na decisão desse casal, você aprovaria a realização do procedimento? Não. Não. De todo jeito, independente disso, sempre entrava com o item desencorajar a esterilização precoce. Não, eu não aprovaria (Íris, enfermeira, 46 anos, trabalha em Hospital, católica praticante).

"A lei garante o direito?", a lei garante, a e o meu parecer, em especial, salvo se o que ela me revelar seja maior do que o direito na lei, eu vou construir um parecer favorável. Eu aprovaria. E assim, eu só não diria que é uma certeza relativa, né, porque eu sempre digo... Digo pro casal e digo aqui respondendo pra você, a decisão é uma decisão sempre datada. Ele tem certeza naquele momento, nós temos certeza das coisas naquele momento. A vida nos põe outras experiências e nos faz arrepender da decisão. Isso não tem como contornar, não tem nenhuma mágica, não tem nenhum profissional que seja mágico nesse sentido, né, você faz o alerta, você faz a reflexão, você pondera, mas nós não somos capazes de abrir a cabecinha da pessoa e fazer com que ela pense e, portanto, proceda a um método intermediário que não seja definitivo, né.

Desencorajar, que eu acho que um... Esse é um outro óbice da lei, o termo, né. Desencorajar já parte do princípio de que não é pra fazer, e aí então põe na lei que não faz né, faz de vinte e cinco pra cima, mas se dá a possibilidade do jovem fazer eu tenho que levar à reflexão, eu tenho que oferecer todos os métodos, eu tenho que ponderar o caráter definitivo, eu tenho que fazer esses exercícios que nós estamos falando aqui, da vida nos apresentar surpresas, né. Num casamento consolidado um carro pega o cara na esquina e ela vira viúva, né, essa é a vida. Eu acho que nós temos 
essa obrigação, o dever profissional de fazer isso, e isso pode significar um desencorajamento.

É. Eu acho que a informação técnica de qualidade não rola, entendeu? Eu acho que não rola. Eu acho que os profissionais, nem todos estão preparados pra isso, e em muitas das vezes impera o bom senso, impera a moral e impera o juízo de valor, de todas as categorias profissionais. Eu não tô aqui fazendo nenhuma distinção entre as profissões. Essa é a minha... O meu achismo. Eu não pesquisei a respeito, mas eu tenho a impressão que é assim (Atena, assistente Social, 50 anos, trabalha em UBS, católica não praticante).

Como podemos observar, nos vários discursos de profissionais apresentados acima, a complexidade que envolve a aprovação e a execução da esterilização cirúrgica passa necessariamente por uma interpretação pessoal do texto da lei, a dubiedade e as controvérsias, contida no mesmo, quando se trata de uma situação clinica de casal jovem reivindicando o seu direito. Nessa situação a prática clínica é, muitas vezes, influenciada por seus valores morais e juízos de valores de profissionais que é pessoal e intransferível. Tal fato se relaciona de maneira estreita, conforme já observada em item anterior, com a natureza da esterilização cirúrgica que, embora considerada caso clínico, antes de caracterizar-se como uma prática médica reveste-se, notadamente em jovens, de uma prática fundamentalmente social, uma vez que em nível de controvérsia que encerra envolve especialmente problemas de natureza sócio-culturais e não de saúde propriamente ditas.

\subsubsection{A respeito da situação de solteiro(a) sem filhos e com idade superior a 25 anos.}

Neste caso, a ideia presente de simulação foi a de apreender a avaliação e a conduta dos profissionais de saúde entrevistados frente a situação de mulher ou homem solteiros sem filhos e com idade maior que 25 anos requerendo a esterilização cirúrgica. Tais aspectos referem-se aos parágrafos da lei 9263/ 96 
que discorrem sobre o tema Art. 10. Somente é permitida a esterilização voluntária nas seguintes situações inciso I: em homens e mulheres com capacidade civil plena e maiores de vinte e cinco anos de idade ou, pelo menos, com dois filhos vivos, desde que observado o prazo mínimo de sessenta dias entre a manifestação da vontade e o ato cirúrgico, período no qual será propiciado à pessoa interessada acesso a serviço de regulação da fecundidade, incluindo aconselhamento por equipe multidisciplinar, visando desencorajar a esterilização precoce; Inciso II § 5№ vigência de sociedade conjugal, a esterilização depende do consentimento expresso de ambos os cônjuges. Abaixo, descrevemos o caso simulado:

Se o $\mathrm{Sr}(\stackrel{\text { a }}{)}$ estivesse escalado para opinar na seguinte situação: Homem ou mulher solteira com idade maior que 25 anos, sem filhos, que deseja contracepção definitiva através de esterilização cirúrgica. O que o $\mathrm{Sr}(\stackrel{\mathfrak{a})}{)}$ tem a dizer sobre as questões abaixo:

a- $\mathrm{O} \operatorname{Sr}(\mathrm{a})$ acha que a lei garante claramente o direito a esterilização cirúrgica?

c- $\mathrm{O} s \mathrm{~s}\left({ }^{\mathrm{a}}\right)$.aprovaria e executaria o procedimento?

Em alguns discursos de profissionais, a lei não garante claramente a esterilização cirúrgica no presente caso, portanto, os mesmos estão respaldados para não aprovarem ou executarem o procedimento, como expostos a seguir:

Não. Nessa situação, não, a lei não garante. É eu não aprovaria a realização desse procedimento (Nêmesis, enfermeira, 52 anos, trabalha em Hospital, católica praticante).

Acho que a lei não garante a esterilização e eu não aprovaria nesse caso (Ártemis, assistente social, 46 anos trabalha em UBS, católica praticante).

Pra este caso, eu também acho que não. Porque retomo na mesma questão, vai pegar que não tem dois filhos vivos e que por isto não vai ser liberada a cirurgia. Também, como na minha visão de profissional, também não aconselharia, caso essa pessoa... Se ela tiver, realmente, vinte e cinco anos, 
aqui fala mais de vinte e cinco anos, né?

É. Sim, eu estaria orientando, dependendo da faixa etária dessa pessoa, se ela realmente... Não há possibilidade de arrumar um companheiro, de ter um filho ou se caso ela adote um filho e tenha vontade e resolva engravidar, mesmo que for por inseminação artificial, outra questão, estaria orientando, né, mas também já sabendo que a lei não vai aprovar porque ela não tem dois filhos antes. Com esse ou pelo menos, pra mim já diz que tem que ter dois filhos vivos. Para mim, é vinte e cinco anos e mais de dois filhos. No meu entendimento, é isso que a lei passa claro (Graças, psicóloga, 28 anos, trabalha em UBS, católica não praticante).

Não, não garante esse direito. Então, nesse caso, também você não aprovaria a realização do procedimento? Não. Não aprovaria. Eu precisaria ver. Eu, como psicóloga, né, se estivesse em minhas mãos, eu tentaria ver o porquê que esse casal sem filhos, que não é algo comum, não é um caso comum, né, que chegaria aqui e não desejaria mais ter filhos, então eu acho que eu teria que investigar muito bem isso, o porquê (Tália, psicóloga, 46 anos, trabalha em Hospital, católica praticante).

Eu acho que não porque ela não tem filhos. Embora ela tenha a idade, mas não tem filhos e é uma paciente jovem que tem uma vida pela frente. Ela não quer filho hoje, mas e daqui alguns anos? Fico preocupado com a paciente e com o respaldo da lei. Com as duas coisas. Pela idade, é aquilo que eu falei, pela idade sim, mas ela não tem filhos.

Não executaria o procedimento, porque não tá previsto em lei. Porque ela não tem filhos hoje, e ela é jovem, e no futuro ela pode se arrepender. É sempre com as duas coisas. Eu não posso estar preocupado só com a lei ou só com a paciente (risos), eu tenho que ver os dois lados (Hermes, médico, 56 anos, trabalha em Hospital, espírita praticante).

Não, também. Eu não acho que a lei diz isso, que ele tem direito só porque tem vinte e cinco anos. Porque ela tá partindo do pressuposto, aqui, que é... É aí eu vou ter que dizer que a redação não tá das melhores, viu. Eu acho que tudo tá num... Podia ser feito dessa forma desde que a idade de corte não fosse vinte e cinco anos, entendeu? Então eu acho que a idade que foi convencional, vinte e cinco anos. Porque que eu imagino que foi vinte e 
cinco anos? Por que se basearam num volume de problemas de outra situação que não é do sudeste, então eu acho que a idade de corte aqui pro sudeste, ela tem que ser maior do que vinte e cinco anos. Hoje eu tenho um número de pacientes com vinte e cinco anos muito pequeno, casados. Então eu corro o risco, se eu começar a fazer laqueadura em pacientes de vinte e cinco anos que não tem filhos, eu vou acabar arrumando um problema, porque a maioria delas vai ter uma oportunidade de ter filhos com trinta e cinco anos, quarenta anos, e vai se arrepender. Então eu acho que se esse corte fosse trinta e cinco ou trinta e oito, eu faria. Não é o fato de não ter filhos. Eu acho que se a pessoa... Se ela... Se eu percebo que tem maturidade suficiente pra decidir, eu acho que a idade aí passa a ser... Não ser o definitivo. Mas é muito mais provável que aos vinte e cinco anos a pessoa não tenha a maturidade, que eu entendo, necessária pra tomar esse tipo de decisão. Não. Com vinte e cinco anos, não. Não encaminharia. Eu avisaria que eu não faria e que a pessoa tem o direito de procurar outro profissional que tenha outros critérios (Apolo, médico, 57 anos, plantonista, católico praticante).

Não. (Risos). A lei não garante essa esterilização cirúrgica, tá, porque a lei fala de uma estabilidade do casal também, fala dessa união, tá, e não dela ser solteira ou sozinha, né, dela "tá" sozinha, solteira e que ela não tem filhos, tá. Então a lei não protege. Aqui a lei não protege. Não têm o direito, e eu também não aprovaria a realização do procedimento. Não faria de jeito nenhum. Não, não é pelo "tá" previsto na lei. Antes da lei eu já não fazia isso. Por quê? Porque assim, vinte e cinco anos, ela é solteira, como que ela vai desejar uma contracepção? A não ser que ela tivesse uma patologia clínica muito séria. Eu penso porque eu tenho filha de vinte e sete anos, solteira, e de repente se ela encasqueta que ela querer fazer uma cirurgia, eu não vou aprovar nunca, e o que eu faço pra elas é o que eu penso pra todo mundo, tá, tanto pras pacientes minhas, de consultório, quanto pras pacientes da rede pública. Isso, pra mim, não tem diferença. E aqui não envolve a lei, ta (Hefesto, médico, 57 anos, plantonista, católico não praticante).

Para outros profissionais de saúde, a lei garante a esterilização cirúrgica e os mesmos aprovariam ou executariam o procedimento, como nos casos de Hera, 


\section{Calíope, Atena e Láquesis}

Dentro da lei tá claro que ela pode fazer, e uma vez que a pessoa decida isso, mais de vinte e cinco anos, tá decidindo, conhece a lei e quer abrir mão desse, né, dessa condição dela, eu não impediria, não. Nesse caso eu não impediria. Não. Porque eu acho que essa pessoa conseguiu... Porque se ela não tem vida estável, é solteira, e não quer mesmo, acho que é uma opinião dela, ela não quer ter filhos por algum motivo, porque ali ela estaria expressando qual era o motivo dela. Eu acho que o risco de ter arrependimento aí é muito pequeno (Hera, enfermeira, 42 anos, trabalha em UBS, evangélica praticante).

Garante. Executaria. eu me preocuparia com o arrependimento posterior, mas ela já teria tido acesso a tudo isso, e como eu falei, eu acho que tendo acesso a informação e tudo, ela é livre pra ter a decisão que for melhor pra ela. Eu acho que isso não caberia a mim, ir contra um desejo dela e talvez mudar a realidade de vida dela, sendo que ela já tá esclarecida sobre tudo isso e tem, inclusive, o respaldo da lei (Calíope, médica, 38 anos, trabalha em Hospital, espirita não praticante).

A lei garante, claramente, o direito. Eu emitiria parecer favorável, sim. Pelos mesmos argumentos daquele que é muito jovem. A ausência de filhos eu acho que é uma questão, às vezes, muito cultural da gente, a gente... Nem todo mundo foi criado pra ser pai, né. Eu acho que tem, hoje, mulheres, por exemplo, que vivem em vida profissional e que não tem a união estável, a maternidade como um projeto de vida, o que não quer dizer que ela não viva a sexualidade dela e que ela não tenha risco de engravidar por conta dessa vivência. Então eu acho que ela tem, tem esse direito, mesmo sem filhos. Ela ou ele, né, a gente tá pegando o exemplo de mulher, mas poderia ser ele, também (Atena, assistente Social, 50 anos, trabalha em UBS, católica não praticante).

Sim. Neste caso, sim. Como é e/ou, ela cumpre. Então, ela tem vinte e cinco anos, entendeu? Acima de vinte e cinco anos ela pode ter, ou não, filhos. Executaria. Desde que passado por toda a tramitação, conforme a gente já discutiu, se ela estivesse lúcida, claro, se tivesse muito claro pra ele. 
Ninguém é obrigada a ter filhos. Onde que tá escrito que todos os homens e mulheres são obrigados a ter filhos? (Láquesis, médica, 55 anos, plantonista, católica não praticante)

Para muitos dos profissionais entrevistados a lei garante, mas, não aprovariam ou executariam o procedimento por não concordarem com a lei:

Quanto ao método definitivo. E a questão dos filhos, ela menciona que poderia ser aprovada. Porém, eu não estou de acordo com essa lei, porque pacientes sem filhos não seria um critério pra ser incluído numa decisão de cirurgia definitiva. Não aprovaria. Mesmo se tiver o respaldo da lei, eu sou contrária (Erínias, assistente social, 50 anos, trabalha em Hospital, evangélica não praticante).

Garante. A lei garante. você nesse caso, como profissional, você aprovaria a realização desse procedimento? Também não. Não. É que eu não sou muito favorável à esterilização, né. Não. Já tive pessoas, né, que fizeram nessa situação. Eu acho bem polêmico, mas se eu também tivesse um papel... É que eu, no geral, eu não sou favorável à esterilização, né (Íris, enfermeira, 46 anos, trabalha em Hospital, católica praticante).

Então eu não acho que a lei garante esse direito a essa mulher, eu não aprovaria. Eu tentaria conversar com ela, bastante, a respeito dos métodos contraceptivos, sem ser o definitivo, né, os de barreira, os hormonais. Eu tentaria conversar com ela, bastante, mesmo porque ela com vinte e cinco anos ainda é uma mulher ou um homem jovem que pode mudar de opinião (Hebe, enfermeira, 46 anos, trabalha em UBS, espírita praticante).

Desse jeito que tá nesse artigo, maior de vinte e cinco anos e o resto é um ou, então ele não precisa, necessariamente, ter um filho. Ele pode, sendo maior de vinte e cinco anos, não querer ter filhos. Também, ela pode. Essa pessoa poderia. Eu não aprovaria, com vinte e cinco anos, se a pessoa tivesse vinte e cinco anos e queria a esterilização, eu também teria... Não concordaria, de pronto. Com vinte e cinco anos. Agora, por exemplo, uma pessoa já com quarenta anos aí eu já mudaria de ideia (Eufrosina, psicóloga, 54 anos, trabalha em UBS, católica praticante). 
Sim. Poderia fazer. Tem o direito à esterilização cirúrgica, sim.

Não. Não aprovaria. Porque ela não tem filho nenhum. Eu não faria a esterilização. Eu orientaria um método. (Anfitrite, médica, 39 anos, casada, trabalha em UBS, católica não praticante).

Eu acho que cai na mesma... No mesmo... Da discussão anterior, né. Se a gente for levar ao pé da letra a lei indica, mas se eu tivesse na outra ponta eu não faria. Então vai contra... É da minha discordância da lei, né. (Aristeu, médico, 54 anos, trabalha em UBS, católico praticante).

A lei garante, mas eu jamais faria. Nunca fiz e jamais faria na minha vida, até eu me aposentar (Eros, médico, 56 anos, trabalha em UBS, espírita praticante).

Aí vamos voltar àquela lei que fala ou, né. Esse ou é que deixa a gente assim... meio encafifado. A gente pensa muito nesse ou, que tá falando aqui, é esse ou que atrapalha, né. Eu acho que tem que ter filhos, sim. Por mais que a paciente... Que a pessoa fale assim "Eu não quero ter filhos", né. Mas eu não faria, também, nessa situação. Eu não executaria, apesar de estar previsto na Lei (Ares, médico, 46 anos, trabalha em UBS, católico praticante).

Garante. É a mesma questão anterior, só que invertendo os critérios de elegibilidade. Ou seja, no caso é um indivíduo sem prole, porém ele tem uma idade superior. Como a lei estabelece o número de filhos ou a idade mínima, eu entendo que a lei está garantindo o direito à esterilização pra esse cidadão. Não, também não realizaria, pelo mesmo motivo. Eu acho que é uma situação extrema, é um indivíduo que tem condições de estar utilizando o método contraceptivo reversível, é uma fase da vida em que existe uma série de dúvidas e eu exerceria o meu direito, no, caso de não realizar um procedimento desse tipo (Zeus, médico, 51 anos, casado, trabalha em hospital, não é adepto a nenhuma religião).

Sim, a lei garante. Não, não executaria. Porque eu acho que ela poderia optar por outro método, uma vez que ela não tem filhos, tá, então que ela poderia aguardar. Ela teria amparo legal, mas eu não faria por ela não ter 
filhos (Dionísio, médico, 50 anos, plantonista, espírita praticante).

É a lei diz que se tiver mais de vinte e cinco anos poderia fazer, né, então, teoricamente, pela lei poderia. Também não executaria o procedimento. Eu deixaria ela à vontade pra procurar outro profissional e tentaria convencê-la de que existem outros métodos, né. Porque eu acho que, também, com vinte e cinco anos às vezes a pessoa não tem maturidade. Eu acho que ela ainda jovem. Às vezes... Eu não realizaria. E nem ele. Acho que poderia, também, outros métodos. Eu acho que tentar outros métodos primeiro, antes de você ir pra um procedimento irreversível ou que seria difícil reverter, então (Átropos, médica, 41 anos, trabalha em Hospital, católica não praticante).

Eu, a minha interpretação da lei é que ela garante, sim, claramente. Então, olha, aqui eu fiquei com uma dúvida, porque assim, homem ou mulher solteira com idade maior que vinte e cinco anos. Maior que vinte e cinco pode ser quarenta. Pode ser trinta e cinco. Supondo que ela tenha trinta anos, quarenta anos. Que seja maior do que vinte anos, vinte e cinco anos. Eles não têm filhos, e que desejam a contracepção definitiva através de esterilização cirúrgica. Então, pra mim a idade faz diferença. Se eu for pensar que eles têm vinte e cinco anos, pela lei eles poderiam fazer, mas eu não faria. Agora, supondo que eles tenham mais que trinta e cinco, eu acredito que eles já estariam numa fase que permitiu um amadurecimento, uma exposição a um número de relacionamentos, que essa opção com trinta e cinco anos pra mais, com certeza, no meu modo de ver seria mais segura do que um homem ou uma mulher com vinte e cinco. Então eu gostaria de responder dessa forma. Quarenta, eu faria. Acima de quarenta, eu faria. Eu acho que a idade mínima aí, realmente, seria quarenta (Afrodite, médica, 48 anos, trabalha em Hospital, católica não praticante).

Nos discursos de Deméter, Eumênides e Nikê, há o reconhecimento da ambiguidade do texto da lei em relação a este caso gerando dúvidas, mas também afirmam que não aprovariam ou executariam o procedimento:

Aí eu já acho mais complicado. Eu acho que precisaria ficar um pouquinho mais especificado isso, na lei. Dá muita margem a dúvidas, mas aí eu acho 
que já seria um processo mais complicado pelo fato de eles não terem filhos. Eu nunca me deparei com uma situação dessas. Eu sei que é muito frequente em outros países, como os Estados Unidos, mas aí eu acho, já, mais complicado. Aí eu acho que eu teria receio de fazê-lo. Eu acho que aí a chance de arrependimento é muito maior. Não. Não executaria. Apesar de estar previsto na lei. Vinte e cinco anos, sem filhos, eu acho complicado (Deméter, médica, 55 anos, trabalha em UBS, católica não praticante).

Não, não está claro. Então assim, a gente tem a lei ali que fala, então a partir de dezoito anos e dois filhos vivos as mulheres poderiam fazer a esterilização, né, e uma pessoa com vinte e sete anos e sem filho nenhum poderia fazer, também, a esterilização, ou vinte e cinco anos, sem filhos nenhum. Então o quê que a gente vê aqui é que seria um absurdo esterilizar uma pessoa de vinte e sete anos que não tem filho nenhum. É um absurdo isso, né, sendo que uma pessoa de vinte e cinco anos, a vida dela, hoje... Tá iniciando a vida. Então hoje ela tem um projeto, mas amanhã ela pode ter outro. Então é melhor a gente, mais uma vez, voltar na questão da educação, né, pra ela conhecer os métodos, e depois ela voltar pra decidir o que ela quer fazer realmente. Não. Nesse caso, não. Com certeza, não aprovaria. Tem conflitos, né. É uma lei contraditória (Eumênides, assistente social, 40 anos, trabalha em Hospital, católica praticante).

Que eu saiba, não. Nessa circunstância de uma pessoa que esteja bem e optar por isso, se tem esse item eu desconheço, e eu não faria. A lei não garante claramente o direito? Claramente, não. Eu acho que deixa dúvida na interpretação. E eu não faria. Independente de estar respaldada, eu não faria. Exatamente, nesse caso, sim, eu poderia encaminhar pra outra pessoa. Mais do que no anterior. No anterior eu acho que eu tentaria convencer o casal. Nesse aqui eu acho que é uma pessoa que tem muito mais clareza do que quer, provavelmente, mas eu não me sentiria à vontade de fazer e encaminharia pra outra pessoa (Nikê, médica, 48anos, plantonista, espírita praticante).

Para Agalaia a lei gera dúvidas, mas diante de uma decisão madura da mulher ou homem, ela aprovaria a execução do procedimento, porque avalia que 
a lei é afirmativa de direitos, nesse caso.

É esse ou da lei gera dúvidas, né. Eu acho que a lei garante, sim, porque a lei tá dizendo que é vinte e cinco anos ou dois filhos tá. Diante de uma situação que ele já vem com uma ideia, né, preconcebida, já tem um processo em andamento, ele já solicitou, ele tem vontade, tem uma segurança na sua decisão, e diante dessa situação você aprovaria a realização do procedimento? Se a pessoa é uma pessoa lúcida, tudo depende, né. Por isso que eu digo, eu acho que tudo depende da avaliação que a gente vai fazer do caso, né. Vinte e cinco anos, não deseja ter filhos, dependendo da argumentação que ela coloca uma pessoa lúcida, consciente, tá com as suas faculdades mentais preservadas, né. Eu acataria, sim (Agalaia, psicóloga, 52 anos, trabalha em Hospital, evangélica praticante).

Nos discursos apresentados podemos observar que a esterilização envolvendo indivíduos solteiros e sem filhos dividem as avaliações dos diferentes profissionais, pois a lei gera interpretações distintas pela falta de clareza em sua redação, acarretando muitas vezes conflitos e controvérsias, a exemplo do caso relativo à idade precoce, para uma tomada de decisão. Podemos apreender, neste caso, a preocupação constante de alguns dos profissionais em cumprir a lei, contrariando muitas vezes os seus valores pessoais, implicando dilemas da prática profissional. Assim, a questão do dilema no caso da esterilização cirúrgica apresenta-se notadamente quando 0 profissional tem que executar 0 procedimento em determinadas condições que vão contra seus princípios e valores morais e éticos. 


\subsubsection{A respeito de homem ou mulher com mais de 2 filhos e mais de 25 anos sem parceiro atual.}

O intuito na simulação deste caso clínico foi o de explorar como e em que termos a ausência do estado conjugal de homem ou mulher com mais de 2 filhos vivos e com idade acima de 25 anos reivindicando a esterilização cirúrgica poderia ter na decisão de profissionais. Os parágrafos da lei 9263/96 que discorrem sobre o tema, Art. 10, apresenta a seguinte redação: somente é permitida a esterilização voluntária nas seguintes situações inciso I: em homens e mulheres com capacidade civil plena e maiores de vinte e cinco anos de idade ou, pelo menos, com dois filhos vivos, desde que observado o prazo mínimo de sessenta dias entre a manifestação da vontade e o ato cirúrgico, período no qual será propiciado à pessoa interessada acesso a serviço de regulação da fecundidade, incluindo aconselhamento por equipe multidisciplinar, visando desencorajar a esterilização precoce; Inciso II $\S 5^{\circ} \mathrm{Na}$ vigência de sociedade conjugal, a esterilização depende do consentimento expresso de ambos os cônjuges. Abaixo, descrevemos o caso simulado:

Se o $\mathrm{Sr}\left({ }^{(\underline{a})}\right)$ estivesse escalado para opinar na seguinte situação: Homem ou mulher com mais de 25 anos com 2 filhos vivos, sem vida conjugal opta pela esterilização cirúrgica. O que o $\mathrm{Sr}\left(\stackrel{(}{a}^{2}\right)$ tem a dizer sobre as questões abaixo:

a- $\mathrm{O} \operatorname{Sr}(\mathrm{a})$ acha que a lei garante claramente o direito a esterilização cirúrgica ?

b- $\mathrm{O}$ sr(a $)$.aprovaria e executaria a realização do procedimento?

Nos discursos apresentados, a lei garante a esterilização cirúrgica no caso em análise, no entanto, o cumprimento da lei varia nos referidos discursos tendo em vista motivos que, a exemplo dos casos anteriores, se circunscrevem a esferas para além da prática médica, demonstrando que, notadamente em casos como a esterilização, a prática médica, antes de prática técnica, é uma prática social, conforme já demonstrava DONNANGELO em seu clássico estudo sobre Saúde e Sociedade (DONNANGELO, 1976). Nos casos abaixo, podemos observar relatos 
de profissionais que reconhecem o direito a esse tipo de demanda, assim como aprovariam e executariam a esterilização cirúrgica.

A lei garante o direito na minha interpretação e eu aprovaria o procedimento

(Atena, assistente Social, 50 anos, trabalha em UBS, católica não praticante).

Nesse caso, acredito que sim. Com mais de vinte e cinco anos e dois filhos. A questão conjugal não foi mencionada na lei e, em minha opinião, se o paciente optar pela cirurgia após um processo educativo e refletido, eu acredito que a lei está garantindo aqui pra ele. Eu seria favorável (Erínias, assistente social, 50 anos, trabalha em Hospital, evangélica não praticante).

Sim, acho. Eu executaria esse procedimento, Sim, com certeza (Dionísio, médico, 50 anos, plantonista, espírita praticante).

Sim. Com vinte e cinco anos e dois filhos, sim. Sim. Esse, sem sombra de dúvidas, eu executaria o procedimento (Láquesis, médica, 55 anos, plantonista, católica não praticante)

Então eu tenho dois filhos, mas eu não tenho uma companheira no momento. Então eu tenho, já, aqueles dois, e mesmo que eu encontre uma companheira no futuro eu não vou querer mais filhos. Então eu acho que a lei assegura, sim, esse direito e aprovaria o procedimento (Hera, enfermeira, 42 anos, trabalha em UBS, evangélica praticante).

Sim. Porque mesmo eles não tendo parceiros fixos, né, não estando casados, numa união estável, vamos colocar assim, eu acho que ele garante. Então se ela tem mais do que vinte e cinco anos e já tem dois filhos, novamente, sempre pensando numa equipe multidisciplinar visando a ação sócio-econômica, né, a parte da psicologia, ou seja, né, da maturidade desse, desse indivíduo, eu acho que garante. Se todos estiverem de acordo, né, eu acho que não tem problema nenhum. Eu aprovaria (Hebe, enfermeira, 46 anos, trabalha em UBS, espírita praticante). 
Acho que a lei garante, porque eu não tô vendo a lei colocar, em momento nenhum, que a pessoa tem que ter vida conjugal. A pessoa só tem que ter os filhos, e em momento nenhum aqui fala de vida conjugal, então a lei garante também. Eu aprovaria (Eufrosina, psicóloga, 54 anos, trabalha em UBS, católica praticante).

Eu entendo que a lei estabelece isso, de forma clara, como sendo um direito, de novo. Ela até cita a questão conjugal, não no sentido de limitar a realização do procedimento, mas no sentido de fazer com que haja a participação do cônjuge, caso haja um relacionamento estável ou uma relação matrimonial, então não tem a ver com a realização do procedimento nessa situação. Ou seja, eu entendo que esse indivíduo tem o direito de ser submetido. Ele estará... A lei tá garantindo a ele esse direito de esterilização. Esse é um procedimento que eu realizaria. Uma paciente que tem mais de vinte e cinco anos, eu até vou voltar ao que eu falei anteriormente, eu tô considerando vinte e cinco anos como sendo... Pode ser vinte e seis, mas também pode ser uma idade superior, mas é uma paciente que já têm seus dois filhos vivos. Eu não sei se ela vai ter um novo parceiro no futuro, se ela vai ter um novo relacionamento, mas eu acho que ela já tem uma condição etária, uma condição em termos de prole que, do meu ponto de vista, é suficiente pra que eu possa estar indicando. Estar aceitando, e é óbvio que eu tô respeitando a lei, por isso que eu faço isso de forma tranquila. Esse é um procedimento que eu aprovaria (Zeus, médico, 51 anos, trabalha em hospital, não é adepto a nenhuma religião).

Eu acho que a lei fala que se você tem parceiro você tem que ter o consentimento do parceiro, se você não tem o parceiro você pode ter uma assinatura de uma testemunha que consta no processo. Eu acho que não tem problema nenhum. Aprovaria tranquilamente (Deméter, médica, 55 anos, trabalha em UBS, católica não praticante).

Sim. está previsto no texto da lei . Faria normalmente o procedimento.

(Anfitrite, médica, 39 anos, trabalha em UBS, católica não praticante).

No discurso de outros profissionais a lei garante igualmente o direito, mas esses aprovariam ou executariam, primeiramente, o procedimento após 
desencorajarem a esterilização precoce e terem a certeza do convencimento da decisão "consciente e madura" por parte dos usuários. Nesses casos são frequentes as avaliações das demandas levando em conta não somente o procedimento em si, mas a inserção da esterilização no contexto de uma prática de planejamento familiar, além das consequências da esterilização como irreversível, com implicações para propostas de vida futuros por encerrar as possibilidades de arrependimento. Neste tipo de avaliação, estarem em jogo não somente condições sociais e de vida das mulheres e homens, mas igualmente, questões psicológicas que aponta para a questão da autodeterminação ou autonomia dos indivíduos em suas decisões.

Eu continuo achando que sim. Então, depende da história pregressa, né, deste homem ou desta mulher. Então eu iria avaliar todas as questões, né, e eu aprovaria dependendo da argumentação e da avaliação feita. É aquilo que eu falei, eu acho que a gente tem que escutar a história anterior, né, da pessoa, avaliar o momento presente, porque precisa se ver porque que ela está optando por isso no momento atual, e fazer com ela toda uma perspectiva de futuro, né, a possibilidade de uma nova relação, a possibilidade de um novo parceiro, a possibilidade do desejo de novos filhos, a possibilidade da perda dos filhos atuais, eu acho que isso tudo tem que ser avaliado. Então eu acho que mediante a avaliação, né, eu não vejo problema nenhum pra realizar o procedimento. Eu acho que se a pessoa tá consciente dos riscos cirúrgicos, se ela tá consciente do momento atual, das consequências dessa decisão, se ela tá respondendo plenamente pelas suas faculdades mentais, tá emocionalmente estabilizada, né, eu acho que eu não teria problema nenhum em fazer a esterilização cirúrgica. Agora, se ela não está emocionalmente equilibrada, se ela tem algum problema cognitivo, né, se ela tá vivendo uma situação circunstancial, eu acho que isso tudo nós temos que avaliar. Eu aprovaria. Esgotadas todas as possibilidades anteriores (Agalaia, psicóloga, 52 anos, trabalha em Hospital, evangélica praticante).

Tá. Em minha opinião, pela lei, eu acredito que seria um caso que seria aprovado, tá? Pela lei. Mas por mim, como profissional, né, que eu dei os outros casos por mim e pela lei, eu acredito que esse também seria um caso 
de estar fazendo uma orientação, porque às vezes pode estar se encontrando um novo companheiro que não tenha filhos e realize esse desejo de ter um filho, também, então eu estaria fazendo essa orientação, mas acredito que, pela lei, não teria algum problema. Mesmo falando que em homens e mulheres com capacidade civil plena, né. Se ela tá consciente que ela não quer mais ter nenhum companheiro e ela está ciente disso, eu acredito que esse caso se encaixa dentro da lei e ela faria a cirurgia sem problema. Exatamente. Então assim, por tá previsto na lei e na minha visão não teria problema, como os outros casos, eu acredito que por um tópico dentro do artigo teria este problema, como neste terceiro, neste terceiro caso não teria, porque não tem uma vida conjugal, são solteiros, mas têm dois filhos. Mas se a pessoa está ciente e consciente que é isso que ela quer, ela está definitivamente decidida, eu não posso tá impedindo ou interferindo nessa decisão. Eu posso estar orientando e mostrando os possíveis arrependimentos que possa ter, futuramente, pra esta pessoa, mas eu estaria encaminhando, sim, pra cirurgia, se ela tem isso ciente (Graças, psicóloga, 28 anos, trabalha em UBS, católica não praticante).

Eu acho que sim. Olha, eu novamente, conversaria com a pessoa, sabendo por quê... Porque é muito jovem, né, se também não tem nenhum problema clínico aí. Só que eu teria que ter certeza o porquê dessa coisa tão definitiva se existem outros métodos. Pela lei, eu aprovaria. Eu gostaria de investigar muito antes, antes de aprovar, ou não, eu gostaria de investigar muito bem o motivo pelo qual tá querendo uma decisão definitiva, né (Tália, psicóloga, 46 anos, trabalha em Hospital, católica praticante).

A lei garante. Tá claro, isso. Nessa situação a gente... É aquele negócio, a gente teria que conversar bastante. Mas provavelmente eu faria, por causa dos dois filhos que ela tem. Eu me preocupo com o arrependimento, sim, em todas as fases da vida, né. Eu tô achando que a paciente jovem arrepende muito mais fácil do que uma paciente que já tá com seus trinta e cinco, trinta anos pra frente, né. Vinte e cinco anos seria uma idade, assim, que a gente pensaria muito e teria que discutir bastante, né, só que eu não... Eu tô falando pra você, o que, é... me permite que eu faça ou não laqueadura são os filhos, né, porque eu acho que, de certa forma, a mãe vai ter que ter a responsabilidade em cima desses filhos também, né. Acho que se ela 
conseguir me convencer de que ela quer isso mesmo, talvez eu fizesse (Ares, médico, 46 anos, trabalha em UBS, católico praticante).

Garante. Executaria. Mais uma vez, eu acho que o arrependimento sempre vai existir, e que essa seria, como eu falei, uma das desvantagens da laqueadura no... Por ser em alguns casos, mais difícil a reversão. Ela vai ter que ter acesso novamente ao serviço público e em alguns casos não seria possível, então eu acho importante a informação, e não ser intempestivo. Talvez até... Passasse pelo protocolo duas vezes, ou sei lá de que maneira que ela tivesse essa segurança. Eu acho que o arrependimento sempre vai existir, independente do caso, mesmo que tenha uma grande prole. Eu acho que as circunstâncias da vida podem mudar e isso pode fazer com que ela mude de opinião, tanto ela como o homem, tanto a mulher como o homem, mas eu acho que eu realizaria. Então, nesse caso eu veria o seguinte: a idade do último filho e tentaria conversar com ela pra esperar um pouco mais já que ela é jovem, né, pra evitar... Eu volto a bater na tecla do arrependimento. Se fosse aprovada, desde que tivesse o respaldo da equipe multidisciplinar. Aí eu faria (Hermes, médico, 56 anos, trabalha em Hospital, espírita praticante).

Eu acho que ela garante. Do ponto de vista legal eu acho que é possível ser feito. Agora, aqui entraria novamente eu conhecer a pessoa, saber... Assim, eu ter um contato com essa pessoa. Se eu realmente conhecesse profundamente essa pessoa, se fosse uma paciente de mais tempo que eu tenha uma vivência com ela e conheça o jeito dela agir, dela pensar, e como ela está, se eu sentisse que, realmente, em todo o relacionamento que eu tenho com ela, é uma decisão madura, eu até faria, tá. Agora, se fosse uma pessoa que eu tivesse na primeira consulta... eu não faria. Se fosse uma pessoa que eu não sentisse, da minha parte, segurança, eu também não faria. Executaria o procedimento só se, realmente, se eu tivesse segurança, assim, na relação médico-paciente de que aquilo realmente é o que a paciente quer (Nikê, médica, 48 anos, plantonista, espírita praticante).

Nos discursos dos profissionais abaixo citados, a lei também garante a esterilização cirúrgica, entretanto, não aprovariam ou executariam o procedimento. 
Sim, a lei garante claramente. Tem vinte e cinco anos, dois filhos vivos.

Sem vida conjugal. A lei garante, mas eu também não faria. Porque eu disse aqui na minha exposição que é fundamental a estabilidade conjugal, o relacionamento, porque esses dois quando forem partir pra outro relacionamento, isso sempre vai demandar outras expectativas em relação à prole, então eu jamais faria por que... Há chance de arrependimento. É muito grande, então eu jamais me colocaria numa arapuca dessas (Eros, médico, 56 anos, trabalha em UBS, espírita praticante).

Também garante. Tem mais de vinte e cinco, né, e com dois filhos vivos. Não. Também não. (Risos). Ah, porque eu acho que a vida muda e eu acho que com vinte e cinco anos, vinte e seis anos, vinte e oito anos, a gente às vezes não têm maturidade pra ter certeza desses procedimentos que eu acho que são irreversíveis, e eu acho que daqui dez anos ela muda de marido, conhece alguém, ou ele conhece alguém e acaba querendo ter filhos, então eu tentaria, também, orientar de outra forma (Átropos, médica, 41 anos, trabalha em Hospital, católica não praticante).

Então, vinte e cinco anos, sem um parceiro, né, e com dois filhos vivos? É também é de... Realmente é da equipe tá refletindo o que tá acontecendo ali, porque hoje, seja homem ou mulher, né, hoje ele tem um projeto de vida e amanhã pode ser que tenha outra pessoa, entre outro cônjuge aí na vida dele. $E$ esse outro parceiro ou não tenha filhos nenhum, ou tenha vontade de ter mais um filho, e se a gente pensar em esterilização pra essa pessoa, futuramente ela pode, né, voltar e falar "Olha, eu fiz uma esterilização naquele momento", como já aconteceu na nossa prática do cotidiano, ela pode voltar e falar "Olha, agora eu quero voltar a ter filhos", né. Então assim, a lei, ela coloca ali, bonitinho, o que pode ser feito, mas se a gente for pensar, e esse indivíduo? Então ora a gente tem que mediar em questão da lei e ora a gente tem que mediar em questão do benefício do paciente, aí. Então não dá pra gente só trabalhar um pouco... Em cima só da lei. Então a gente tem que estar mediando e ver em relação ao benefício a esse paciente, futuramente, e não naquele momento, só. Então realmente, eu também não orientaria a fazer a esterilização. Se eu tivesse que decidir, não aprovaria (Eumênides, assistente social, 40 anos, trabalha em Hospital, católica praticante). 
Nessa situação a lei garante né. Diante da manifestação e da segurança do casal em realizar, você aprovaria a realização deste procedimento? Também não. Sem vida conjugal. Não concordaria. Eu tentaria convencer o casal a usar um método. E se você fosse médica, também não faria (Nêmesis, enfermeira, 52 anos, trabalha em Hospital, católica praticante).

Garante, mas... Entra o... Tudo isso aqui vai cair, assim, no mesmo das outras duas questões, né, que no meu ponto de vista eu acho importante a situação social do casal. Então é temerário fazer isso, fazer... O índice, sem dúvida, é maior. Na experiência que a gente tem é muito grande, né, o arrependimento. E a possibilidade de contrair um novo matrimônio, é simplesmente isso, assim (Aristeu, médico, 54 anos, trabalha em UBS, católico praticante).

Então, aqui, em minha opinião, cai na mesma situação da anterior. Pra mim, na minha concepção, é diferente uma pessoa com mais de vinte e cinco, mas se ela tiver vinte e cinco, vinte e seis, ou se ela tiver trinta e sete, trinta e oito, quarenta. Suponha que seja uma pessoa madura, né. Porque a lei fala em maior do que vinte e cinco anos. Ele não fixa uma idade mínima, é maior do que vinte e cinco anos, isso é o que está previsto na lei. Então, mas pra mim essa é a grande questão da lei. Eu acho que essa idade mínima, pra quem não tem sociedade conjugal constituída ou para quem não tem filhos, deveria ser bem superior, pelo menos trinta e cinco. Então é o que eu, o que eu faria sem conflitos. Ou seja, uma pessoa de vinte e cinco, dois filhos, sem união conjugal, eu não faria, mas essa mesma situação pra uma pessoa acima de trinta e cinco, por exemplo, eu faria. A idade limite aí nesse caso, com dois filhos vivos, pra mim seria trinta e cinco (Afrodite, médica, 48 anos, trabalha em Hospital, católica não praticante).

Somente para Apolo, médico, a lei não garante claramente o direito à esterilização cirúrgica e, portanto, não a executaria:

Não, também. Eu acho que a lei não garante claramente isso. Eu acho que ela, a pessoa tá em dois critérios aí, ter dois filhos vivos ou vinte e cinco 
anos, mas naquele meu protocolo inicial exigia uma união estável. É, eu tô vendo que eu concordo com a lei, mas quase tudo que a lei quer eu não faço, né. (risos) (Apolo, médico, 57 anos, casado, plantonista, católico praticante).

$\mathrm{Na}$ interpretação da lei, o fato de não ter uma vida conjugal, ou seja, ser solteiro, não parece ser para a maioria dos profissionais, um fator impeditivo para esterilização cirúrgica, muito embora a preocupação com o possível arrependimento se encontra presente em muitos dos discursos. Notadamente naqueles em que profissionais parecem ponderar mais as implicações da esterilização como procedimento irreversível, notadamente para novos projetos de vida futuros que envolvam novas uniões conjugais e novos desejos de terem outros filhos. Em tais casos colocam-se tanto aqueles profissionais que prescreveriam desestimular a cirurgia orientando para outros métodos, mas realizando-a diante da forte convicção, assim como aqueles que apesar de reconhecerem o direito não aprovariam nem executariam o procedimento. Nesses casos, os discursos parecem revelar que alguns profissionais sentem-se igualmente responsáveis pelas implicações futuras que possam advir na vida dessas mulheres e homens por avalizarem tal procedimento, o que se Ihes apresentaria como dilemas de decisões.

\subsubsection{Sobre a situação de momento do parto com processo aprovado, ter indicação médica de parto cesárea e a mulher não ter duas ou mais cesáreas anteriores.}

Nesta simulação de caso clínico, a intenção foi de explorar, qual seriam a avaliação e conduta dos profissionais de saúde frente a um caso em que a mulher requereu a esterilização cirúrgica durante a gestação e encontra-se com a aprovação pela equipe multidisciplinar que avaliou o caso e no momento do parto, 
embora não possua o histórico de cesáreas sucessivas anteriores, a referida mulher tenha uma indicação médica de parto cesárea. Diante disso a indagação é se os profissionais aproveitariam o abdome aberto para a prática de laqueadura tubária. Cabe lembrar que embora a execução do procedimento se trate de ato médico na entrevista foi solicitado avaliação de outros profissionais da equipe multidisciplinar.

Os parágrafos da lei que normatizam esta questão se encontram no Art. 10, e se apresentam nos seguintes termos: Somente é permitida a esterilização voluntária nas seguintes situações: Inciso II - risco à vida ou à saúde da mulher ou do futuro concepto, testemunhado em relatório escrito e assinado por dois médicos, $\S 2^{\circ}$ É vedada a esterilização cirúrgica em mulher durante os períodos de parto ou aborto, exceto nos casos de comprovada necessidade, por cesarianas sucessivas anteriores. Foi assim indagado aos profissionais, conforme decisão do caso abaixo, se haveria impedimento da esterilização durante a cesárea nessas condições. Abaixo, descrevemos o caso simulado:

Se o $\operatorname{Sr}\left(\stackrel{a}{ }^{\prime}\right)$ estivesse e escalado para opinar na seguinte situação: Mulher que têm processo de laqueadura tubária autorizada pelo planejamento familiar, estando gestante, sem cicatriz de sucessivas cesáreas anteriores, que porventura tenha indicação médica de cesárea no momento do parto está impedida de ter a sua laqueadura realizada durante o parto.

a- Em sua opinião estará impedida de realizar o procedimento? b- Se não estiver impedida o por quê ?

Para muitos profissionais, em sua interpretação, elas estariam impedidas, pela lei, de serem esterilizadas nesta situação e não executariam o procedimento por este motivo:

Ela não tem duas cesáreas sucessivas, anteriores. Então não pode fazer no momento do parto. Ela está impedida pelo texto da lei. Porque só pode sessenta dias após este parto, mesmo que ele tenha sido uma cesárea. Não faria, nesse caso. Não faria em hipótese alguma. (Anfitrite, médica, 39 anos, trabalha em UBS católica não praticante). 
Pela lei, sim. Pelo texto da lei ela tá impedida, mas ela é uma pessoa que não deveria engravidar mais, assim. Então eu acho assim, é aí que a lei falha. $E$ eu sei que eles fizeram essa lei porque isso dá uma margem, um monte de interpretação lá, que eles vão achar brecha na lei. Talvez faria. Ultimamente a gente não tem feito, praticamente não tem feito, e justamente por causa da lei (Aristeu, médico, 54 anos, trabalha em UBS, católico praticante).

Nesse caso, sim, ela tá impedida. O médico não deverá fazer porque caberão punições aqui pro médico e a equipe. Então eu sou contrária (Erínias, assistente social, 50 anos, trabalha em Hospital, evangélica não praticante).

A lei proíbe, né. Aqui a lei proíbe. Então não deve ser feito. Eu não faria porque eu estaria fazendo uma coisa contra a lei, e nisso eu estaria me submetendo a um processo, diante do CRM, inclusive Ético disciplinar, então eu não faria. Eu acho assim, se a gente analisar objetivamente, com o campo aberto, né, o certo seria já aproveitar pra se fazer a laqueadura, mas tem certos, certos procedimentos que a gente não pode ir contra a lei, né. Então aqui, como eu estaria indo contra a lei, apesar de achar muito conveniente, seria conveniente... Eu acho que seria o termo certo, seria conveniente, mas não seria prudente, então eu não faria (Eros, médico, 56 anos, trabalha em UBS, espírita praticante).

Sim. Porque a lei é clara, ela diz que a laqueadura no momento do parto é só por múltiplas cesáreas anteriores ou por risco de vida materno. Se a indicação de cesárea foi por qualquer outra situação que não envolva risco de vida materno, eu não posso estar realizando a laqueadura no momento do parto. Tá impedida. Não eu não faria porque a lei aqui é bastante clara e... Assim, no meu entendimento eu acho uma pena, realmente, a paciente ter que se submeter a todo esse processo de internação, de passar por uma nova anestesia e por uma nova cirurgia, porém, a lei nesse aspecto coloca múltiplas cesáreas anteriores ou risco de vida materna. Se não cair nessa situação, eu não faria. (Afrodite, médica, 48 anos, trabalha em Hospital, católica não praticante). 
Sim. A lei, infelizmente, isso que eu coloquei no começo, essa parte do texto me parece muito infeliz. Porque não se contemplou a possibilidade de uma realização de uma esterilização no período, vamos chamar de pós-parto imediato, ainda durante o próprio procedimento, e que foi uma falha do texto, no meu modo de entender e, portanto, se nós vamos cumprir a lei essa é uma mulher que não pode ser submetida, salvo se ela estiver contemplada na Portaria, como eu falei na Portaria 48 da SAS, mil novecentos e noventa e nove, que estabelece essa possibilidade caso um novo procedimento cirúrgico-anestésico seja considerado de alto risco. Ou seja, se houver alguma comorbidade que vá fazer com que uma nova, um novo procedimento cirúrgico-anestésico seja considerado de alto risco, que é uma coisa difícil de avaliar, inclusive, aí sim, mesmo sem as cesáreas anteriores, não por força da lei, mas por força dessa complementação de alguns anos após. Mas nesse caso em particular, subentendendo que ela não é portadora de alguma comorbidade, uma cardiopatia ou alguma coisa assim, eu entendo que ela não pode ser submetida a esse procedimento. Mesmo. Como eu disse, assim, a lei, ela tem um aspecto dela que me incomoda, que é de novo o da regulamentação. Agora, já que eu sou obrigado a cumprir, afinal, a lei, eu acho que ela tem que ser cumprida na sua totalidade e, portanto, eu vou cumprir e vou cumprir respeitando esse aspecto. Eu acho que é importante, inclusive, tentar mudar. Não vejo grandes perspectivas, mas o texto, pra mim, é muito claro. É um texto infeliz, no meu modo de entender, mas ele é muito claro e eu entendo como sendo uma clara proibição nesse caso, em particular, que tá sendo colocado (Zeus, médico,

\section{1 anos, trabalha em hospital, não é adepto a nenhuma religião).}

Olha, pela lei, não, né. Porque aqui diz que são, pelo menos, duas, né, cesáreas sucessivas, anteriores, e no caso ela não tinha. E assim, e nessa... E que ela não tem a... Ela tem a indicação médica pra cesárea para aquele momento. Então eu não faria a laqueadura porque eu estaria respaldada na lei (Tália, psicóloga, 46 anos, trabalha em Hospital, é católica praticante).

Sim, estará impedida. Não, eu não executaria. Porque a lei não permite que se faça esterilização cirúrgica em mulheres durante o período do parto, sem que ela tenha duas ou mais cesarianas, ou cesarianas sucessivas. $E$ você 
acha que mesmo ela tendo que ser submetida a uma nova internação, uma nova anestesia e uma nova... Uma nova cirurgia, né, num momento posterior ao parto, você, nessa situação, você não... Eu não faria. Neste caso eu contemplaria a lei, não faria e estaria amparado (Dionísio, médico, 50 anos, plantonista, espírita praticante).

Para outros profissionais, a sua interpretação é a de que a lei não impede a realização do procedimento nesta situação e, portanto, executariam a laqueadura tubária:

Em minha opinião ela não está impedida, eu consentiria o procedimento. Éo questionamento que as mulheres faziam. "Pô, eu já tô com a barriga aberta. Quer dizer, eu vou ter que voltar lá pra fazer de novo todo o processo?". Elas questionavam essa questão. Elas questionavam. Elas falavam "Porque que já não se aproveita e faz?" (Ártemis, assistente social, 46 anos, trabalha em UBS, católica praticante).

Ela não tá impedida, tá, de jeito nenhum. Eu acho que o fato de não ter cesáreas anteriores, sucessivas, não é um fator de extrema... Embora esteja aí na lei, eu não acho que não é um fator de extremo impedimento pra que seja realizada a laqueadura, uma vez que já foi expressa a vontade, tem a documentação e ela tá dentro do perfil que pode ser realizado. Sim se fosse médica faria sim. Porque eu acho que eu diminuiria os riscos dela pro futuro. Porque se eu não fizesse agora eu teria que submeter essa mulher a uma nova internação, anestesia e cirurgia. Eu faria (Hera, enfermeira, 42 anos, casada, trabalha em UBS, evangélica praticante).

Não, eu acho que o médico já deveria aproveitar e fazer a laqueadura. Não está impedida. Se ela já tem... É, se ela já tem um processo de planejamento familiar feito, está "okay", ela está numa intercorrência, ou seja, nada daquilo foi planejado, né, o planejado seria mais um parto normal, eu acho que ele deveria aproveitar e já fazer. Porque a coisa mais... Eu acho que mais agravante é assim, é ter a sua barriga aberta, vamos colocar assim (Hebe, enfermeira, 46 anos, trabalha em UBS, espírita praticante).

No discurso de muitos profissionais, a interpretação da lei é a de que a 
mulher está impedida nessa condição, entretanto executariam o procedimento em benefício do paciente poupando-a de uma nova internação, nova anestesia e nova cirurgia, mesmo com o risco de contrariar uma lei:

Pelo... Bom, é que aqui fala "esterilização cirúrgica em mulher durante os períodos de parto ou aborto, exceto nos casos de comprovada necessidade por cesarianas sucessivas anteriores", então como ele coloca cesarianas sucessivas anteriores... Então eu faria, mas a lei não diz isso, o problema é esse, né. É, se for seguir a lei ao pé da letra, está impedida. Pois é, porque aí ela vai ter o bebê, ela vai ter que esperar uns seis meses e aí a preocupação dela é com o bebê. Então é complicado, né. Se é pra fazer, então faz de uma vez. Mesmo, né, em tese, contrariando a uma lei, vamos

dizer assim. É, porque é exceto nos casos de comprovada necessidade. Então você pode alegar que teve necessidade de fazer, né (Nêmesis, enfermeira, 52 anos, trabalha em Hospital, católica praticante).

Pela lei ela tá impedida. Aí fica uma situação saia justa, até, pro médico, né, se eu fosse o médico. Porque, por lei, ele vai fazer... Se ele fizer ele vai "tá" fazendo uma contravenção, né. Por outro lado, quando a gente vê aqui no atendimento, do nosso atendimento de grupo, to colocando isso como experiência, a pessoa já tá indicada pra uma cesariana. Depois que ela fez a cesariana nós vamos encaminhar ela de novo pra uma cirurgia, ela vai correr um outro risco, vai ter gastos também, se a gente for ver até do ponto de vista financeiro, ela vai de novo pra um centro cirúrgico, ela vai ocupar uma equipe médica, a gente vai correr esse risco, ela vai correr esse risco de ter que fazer outra cirurgia, que a laqueadura é invasiva, não tem como. Aí é um problema complicado. Assim, se fosse médica eu faria (Eufrosina, psicóloga, 54 anos, trabalha em UBS, católica praticante).

Tá. Entendi. É, pela lei, ele não tá contemplando fazer essa cirurgia no momento do parto, tá claro que não tá... Pela lei, não autoriza a fazer, mas em minha opinião eu acredito que deveria fazer, né, porque a pessoa já tá ali, né, ela já tá, vamos dizer, na linguagem mais popular, já tá ali aberta pra tá, né, pra fazer a cesárea, e já aproveitaria e faria a cirurgia, do que depois que ela se recuperar dos pontos, depois que ela se recuperar de tudo, novamente ela entrar numa sala cirúrgica, porque a gente sabe muito bem 
que... É uma cesárea, novamente, é um novo parto, né, porque são novos pontos, é outra dor, eu acho que ocasiona mais problemas, são mais profissionais que vão tá disponibilizando atendimento pra ela e que poderia tá se disponibilizando pra outro paciente. Se ela já tá ali, não tem problema, já poderia tá fazendo ali, naquele determinado momento. Estaria impedida pela lei. Você ia contrariar a lei, vamos dizer assim? É. (Risos). Porque assim, é complicado falar isso porque, às vezes, né, fala assim "Mas você tá contrariando a leil", né, "Você tem que seguir e tal", mas seria mais ou menos isso. Tá contrariando uma lei pensando no paciente (Graças, psicóloga, 28 anos, trabalha em UBS, católica não praticante).

É, pela lei ela "taria" impedida, né, porque tem que ter, no mínimo, sessenta dias da decisão, ela não pode ser realizada, a laqueadura, durante 0 trabalho de parto. Eu acho isso outra questão discutível a ser revista na lei, né. Porque não fazer, aproveitar um procedimento cirúrgico, já realizar a laqueadura se já foi feita toda uma avaliação? Vamos ter que submetê-la novamente a um novo procedimento cirúrgico que gera mais riscos, gera uma internação, gera todo um custo, né, quando isso tudo poderia ter sido resolvido num procedimento cirúrgico só. Eu realizaria, sim, tá, mas eu precisaria conhecer o caso, porque se eu fosse médica eu sei que isso poderia se reverter contra mim, né, num caso de um arrependimento futuro, no caso de uma má resolução, né, deste parto, que o bebê nasça com algum problema. São riscos que a gente tem né, então, eu precisaria avaliar muito bem o caso. Avaliado o caso, eu acho que eu faria, sim. Eu faria porque eu acho que isso seria melhor pra ela, melhor pro casal, né, eu acho que pra saúde dessa paciente. E também se nós pensarmos que no lugar desta laqueadura daqui a noventa dias, não sei, eu poderia estar atendendo outra paciente, já, né. (Agalaia, psicóloga, 52 anos, trabalha em Hospital, evangélica praticante).

Não, eu acho que deveria ser feita. Eu faria a laqueadura porque ela já tá anestesiada, vai „tá" aberta, vai „tá"... Já tem uma carta de laqueadura. Eu não concordo em eu fechar a paciente e mandar daqui um mês ela voltar, daqui dois meses ela voltar, daqui a sessenta... E aí voltar daqui quarenta dias, pós puerpério, voltar pra eu poder fazer uma cesárea porque ela não vai voltar. Ela vai „tá" com filho recém-nascido em casa, quer dizer, não... Eu 
faria. Eu faria. Eu acho que assim, eticamente eu faria porque acho que seria melhor. Eu penso no paciente (Átropos, médica, 41 anos, trabalha em Hospital, católica não praticante).

Bom, embora a lei diz que não é pra fazer durante a cesárea...Pela lei, a lei diz que se não é interativa não é feito, né, logo no trabalho de parto. Tá impedido de fazer. Agora, vai da cabeça do profissional também. (Risos). Eu acho que eu faria, sim (Hermes, médico, 56 anos, trabalha em Hospital, espirita praticante).

Até onde eu conheço a lei. Antes... Até onde eu conheço a lei, você não tem autorização para a realização da laqueadura numa situação dessa, tá. Agora...Honestamente, sim. Faria. Porque eu acho que não faz sentido você fazer a paciente se submeter a outro procedimento cirúrgico, anestésico, pra realizar algo que já tá aprovado, que já tá caracterizado, que já tem toda uma legalidade. Então independente da lei, né. Eu faria. (Nikê, médica, 48 anos, plantonista, espírita praticante).

Eu acho que „taria" impedido, legalmente, de fazer. Mas, independente da lei, você executaria o procedimento? Eu acho que sim. Nessa aqui, talvez me criasse alguma dúvida se fosse no serviço público. Se fosse uma paciente que eu conhecesse e tudo, eu acho que se tem a indicação da cesárea e eu conheço o caso, eu não acho que isso seja... Porque uma das outras coisas que a lei fez foi evitar que se indicasse uma cesárea... Pra fazer a laqueadura. Aqui diz que a indicação é por outra causa. Então eu vou estar com a barriga aberta e já indiquei a cesárea por outro motivo. Executaria, perfeitamente (Apolo, médico, 57 anos, plantonista, católico praticante).

Só se tiver risco de vida materno, numa próxima gestação, ou risco de vida fetal, pelo que fala lei. Tirando esse risco, ela não pode ser realizada durante o procedimento cirúrgico, só em caso de cesáreas anteriores, pelo menos duas cesáreas. Não pode realizar. Teria que ser quarenta e duas, quarenta e dois dias após o procedimento, o puerpério, né, no quadragésimo segundo dia, que eu também acho... É uma das grandes falhas que eu acho. Quer dizer, você vai reabrir essa mulher, expor a um novo risco anestésico e cirúrgico, sendo que você poderia ter feito quarenta e dois dias antes. Neste 
caso está impedida porque não tá na lei, e como não tá na lei aí complica, né. Porque no dia de amanhã a paciente se arrepende por qualquer outro motivo e ela pode alegar que foi feita de forma irregular, fora da lei, né. E a gente já teve pacientes lá no hospital, você sabe disso, que a gente fez a laqueadura com o consentimento dela e do marido, e dez anos depois ela chegou e falou que não sabia, né, com o termo de consentimento assinado, né. Então o receio é isso, do ponto de vista legal você corre risco. Realmente, quando tem risco de vida aí mais dois colegas assinam e aí eu acho que não tem problema nenhum. $O$ duro é esses casos limítrofes que eu te falei dessa outra paciente minha, por exemplo, né, é uma paciente de trinta e nove anos, sabia o que queria, já tinha dois filhos, eu acho que, perfeitamente, poderia ser beneficiada com a laqueadura (Deméter, médica, 55 anos, trabalha em UBS, católica não praticante).

Não, eu não entendo disso. Na lei eu não entendo... Se eu for me basear pela lei, na realidade, se eu achar que tem uma indicação cirúrgica, tá, eu não vou deixar de fazer uma laqueadura na paciente que eu tô fazendo uma coisa por uma indicação cirúrgica, fazendo uma cesárea. E se ela tiver a indicação médica de "tá" fazendo a cesárea, pra mim é claro que eu posso fazer a laqueadura, tá. Eu não vejo nesse sentido. A lei me fala, lógico, pra mim não fazer a laqueadura, não fazer a cesárea estritamente para laqueadura. Eu entendo assim na lei, tá. Agora, não porque ela não tinha cesárea nenhuma e precisou fazer uma cesárea, e de repente ela não tem o direito de fazer a laqueadura. Não, eu faria a laqueadura. Eu faria o procedimento, normal, tá, mesmo porque eu não indiquei a cesárea dela pra fazer a laqueadura, eu indiquei a cesárea dela por uma não evolução satisfatória, como parto via baixa, tá. Não teve evolução satisfatória, houve realmente uma necessidade cirúrgica, tá, em se havendo o processo todo, tá, é lógico que eu vou fazer, independente de essas questões, "Ah, não, ela não tem cesárea anterior". Pra mim não tem isso e eu entendo que eu estou autorizado a fazer, tanto pela lei quanto pela minha casa... Pela minha consciência... Pelo meu eu, né, de realmente satisfazer o quadro da paciente (Hefesto, médico, 57 anos, plantonista, católico não praticante).

Para Láquesis, esta questão não está clara na lei e interpreta que a 
intenção do legislador foi a de coibir a indicação de cesárea para fins exclusivos de laqueadura tubária e não de proibir aqueles casos de indicação absoluta de cesárea, daí entender que cada profissional interpreta da maneira como entender ou mesmo, ideologicamente falando, como quiser:

Não. Eu a... Assim, a lei é um pouco... Não fica tão claro. Esse é um outro ponto da lei que ela não deixa muito claro, esse aspecto, mas eu não vejo... Eu. Então fica muito da intuição do profissional, mas eu não vejo como impedimento. Não tem cabimento eu anestesiar, colocar em risco essa mulher duas vezes, risco anestésico, risco cirúrgico, todos os riscos possíveis e imagináveis. Eu acho que o que o legislador quis dizer com isso é impedir que as pessoas fizessem a cesárea... A mulher chega pra você, teve um parto normal, "Ah, já que ela vai fazer laqueadura, então eu vou fazer a cesárea". Essa foi a intenção do legislador. Não foi a intenção de coibir aquela que é uma indicação absoluta, entendeu, de ter uma cesariana e de você fazer. É que o que o legislador quis dizer foi isso, entendeu? Agora, as pessoas usam o profissional, de acordo com a consciência de cada um, ele vai interpretar, infelizmente, da maneira como ele quiser. Eu imagino, eu, que o legislador pensou isso. E eu não tenho como colocar uma paciente na mesa, abrir a barriga dela e não fazer a laqueadura dela (Láquesis, médica, 55 anos, plantonista, católica não praticante).

Como podemos observar, o texto da lei traz ambiguidades e gera controvérsias na sua interpretação. Neste caso cada profissional interpreta à sua maneira. Daí, conflitos com a lei estarem presentes na medida em que para beneficio do paciente, médicos procurariam evitar segundo seus valores e visão de mundo e de sua prática profissional, uma nova anestesia, uma nova internação e uma nova intervenção cirúrgica para a mesma, contrariando com isso. Assim, embora entendam que pela lei eles estão impedidos de realizar a esterilização, se arriscam, contudo, a cometer uma ilegalidade, assumindo muitas vezes a possibilidade de serem penalizados.

Nesse particular inscreve-se a narrativa de Láquesis que atenta para usos e abusos da própria autonomia de que o médico dispõe no próprio processo de 
decisão para a realização de esterilização cirúrgica, quando realizada pelos chamados trâmites legais. Isto porque, muito embora em todo processo de avaliação a equipe multidisciplinar possua papel importante para subsidiar decisões médicas, o que pudemos observar, notadamente em relação aos casos aqui relatados, é o de que, em última instância a decisão pela realização ou não do procedimento caberá ao médico. Talvez por isso, sinta-se confortável em decidir, independentemente de um processo anterior de avaliação sobre transgredir ou não a lei em nome de sua própria avaliação pessoal e ética profissional. 


\subsection{Sobre o aperfeiçoamento da lei $9263 / 96$ no discurso dos profissionais.}

A quase totalidade dos profissionais entrevistados consideraram a importância da revisão e aperfeiçoamento da lei, com exceção de dois, Ártemis, assistente social, e Hermes, médico, pelos seguintes argumentos: Segundo Ártemis uma mudança, no texto da lei, relativa, por exemplo, ao parágrafo "idade ou dois filhos vivos", substituindo a conjunção "ou" pela conjunção "e", aspecto considerado um dos mais polêmicos dentre os entrevistados, não permitiria o que considera uma possibilidade atual de flexibilização da lei, valendo lembrar justamente pela ambiguidade do mesmo. Daí não entender a necessidade de alteração no texto da lei atualmente vigente.

Não, porque se você coloca vinte e cinco anos e mais de dois filhos, então a pessoa teria que se encaixar nesses critérios. Eu acho que ali você dificultaria o acesso à esterilização, certo? (Ártemis, assistente social, 46 anos, trabalha em UBS católica praticante).

Para Hermes, não há a necessidade de aperfeiçoamento porque em sua interpretação considera o texto atual da lei claro, portanto, sem ambiguidades. Em relação aos critérios relativos à idade e número de filhos vivos o profissional menciona que sempre interpretou o texto como " 25 anos e mais de dois filhos vivos" e não como "25 anos ou pelo menos dois filhos vivos". Tal interpretação parece ter relação, por um lado, pela sua afirmação de que norteia sua prática profissional muito pela sua consciência e, também, por outro, pela sua observação, como especialista em esterilidade conjugal, de casos de arrependimento e buscas de reversão. Vale observar, assim, que a posição de Hermes, que podemos observar em outros discursos, coloca notadamente à medicina, a questão da autonomia médica frente à complexidade de muitos procedimentos atuais considerados como pertencentes notadamente ao campo da Saúde Pública, que envolvem não somente questões éticas, mas questões morais que ultrapassam os limites da medicina como prática passível de ser considerada puramente técnica quando considerada em suas relações mais amplas no campo 
da Saúde em geral.

Não. Porque eu me baseio muito por minha consciência também, né. (Risos). Sim, porque eu interpreto dessa maneira que eu venho dizendo até agora, é vinte e cinco anos com mais de dois filhos. Então, acho que... Embora a lei respalde a paciente a partir dos vinte e cinco anos, a gente tem que ter cuidado em orientá-la e abrir os olhos da paciente, né, por que...Em relação ao arrependimento, né. Porque em trinta e dois anos o que eu vejo é que cresceu bastante, né. E eu fiz como sub-especialidade a esterilidade conjugal e eu tive a oportunidade de ver bastante esse tipo de coisa. $\dot{E}$ vem crescendo a fila para reversão (Hermes, médico, 56 anos, trabalha em Hospital, espírita praticante).

A lei foi promulgada em 1996, estando vigente, portanto, há quase quinze anos. A contínua mudança da sociedade, principalmente em relação à chamada estabilidade conjugal como padrão esperado ou tradicionalmente observado em nossa realidade, o aumento da oferta de outros métodos contraceptivos, a divergência na interpretação do texto da lei, a experiência adquirida nestes anos em relação à prática profissional e aplicação da lei pelos mesmos e pelos serviços são aspectos que se descortinam nos discursos de muitos profissionais que se manifestaram a favor de um aperfeiçoamento da lei, tendo em vista exercer a sua atividade profissional de uma forma regulamentada, sem constrangimentos e sem conflitos com a sua própria consciência, portanto, notadamente com os seus valores pessoais e profissionais.

Para Atena, assistente social, a lei é datada e, nos dias de hoje, diante das grandes transformações notadamente nas relações sociais, existem dificuldades na aplicação da mesma. Entende que a lei deve ser repensada contemplando, sobretudo, a questão das relações de gênero, especialmente quando se considerada suas implicações no campo da saúde pelo predomínio da laqueadura em relação a vasectomia, fato esse que pode ser observado em sua fala, mas, igualmente, na literatura especializada, como exemplifica o trabalho de MARCHI (2006).

Agora, ela é uma lei datada de noventa e seis, ela tem... Hoje, com a 
experiência prática, um pouco, de trabalhar com essa temática, eu acho que ela tem óbices, ela tem problemas, ela poderia ser repensada e levada em consideração, sobretudo, a determinação de gênero, né. Eu acho que hoje a gente assiste a questão, por exemplo, da opção pela laqueadura, muitas das vezes quando poderia ser um relacionamento estável, tal, é um procedimento muito menos invasivo, como é o caso da vasectomia, mas por um problema de determinação de gênero. Uma sociedade patriarcal, o machismo presente não só no homem, mas presente na mulher também, né, então eu acho que a lei, ela tá datada, como eu disse a você (Atena, assistente Social, 50 anos, trabalha em UBS, católica não praticante).

Para Eumênides, assistente social e Íris, enfermeira, como a lei permite a esterilização cirúrgica de pessoas jovens deve ser dada uma ênfase na conscientização e educação, no sentido de desencorajar a esterilização precoce. Vale observar que no discurso de Eumênides apresenta-se igualmente a questão de gênero, apontada antes por Atena, agora relacionada à importância do conhecimento sobre o corpo, a sexualidade e as saúde sexual e saúde reprodutiva, amplamente discutida nos estudos feministas sobre relações de gênero, identidade, autonomia (SOARES, 1994). No discurso de Íris observamos a menção a problemas clínicos de saúde decorrente de sequelas de esterilizações realizadas em jovens ou adolescentes, laqueadas precocemente, como é o caso mencionado de uma paraibana, com três filhos, que foi laqueada aos vinte e um anos em troca da venda de votos, em um período eleitoral, prática corrente no Brasil notadamente até a promulgação da lei (VIEIRA, 1994).

É vinte e cinco. É, desculpa. Vinte e cinco anos, isso poderia deixar um pouco mais claro, né. Então, ficando um pouco mais claro, eu acho que toda equipe que trabalha com planejamento familiar trabalharia um pouco mais tranquila, né. Porque a lei garante que uma mulher muito jovem, né, sem conhecimento do corpo, sem conhecimento de métodos, sem noção do que tá fazendo ali naquele momento, porque se a mulher não tem conhecimento do próprio corpo, ela não tem, muitas vezes, conhecimento de nada. A gente percebe que ela vem aqui para orientação, realmente, sem conhecer nada ali, como as coisas funcionam dentro do seu corpo e como os métodos vão 
agir ali dentro de seu organismo. Então sim, eu acho que falta mais incentivo, né, mais políticas públicas aí em relação a essa parte da educação, né. Então eu colocaria a educação sexual na escola, no ensino médio. A gente sabe que algumas coisas já estão encaminhando nesse sentido, mas assim, eu mudaria nesse sentido de melhorar essa questão da idade, né. Eu trabalharia mais na questão da educação mesmo, né. Quanto mais precoce essa educação, mais acesso a essa educação, eu acho que menos esterilizações iriam existir. Não, eu acho que a lei tem que ser mais clara, né. Como eu disse no começo, não dá pra ter dezoito anos e dois filhos vivos aí, e a lei garante ali, mas a gente tem que tomar o cuidado aí e conscientizar essa usuária que ela é muito jovem (Eumênides, assistente social, 40 anos, trabalha em Hospital, católica praticante).

Então nisso você já... Isso faz a gente pensar muito em todas essas situações. Porque a gente pode, né, não ter filhos sem partir pra esterilização. Eu não sou muito favorável às situações radicais, assim, cirúrgicas. Então... E outra que a gente vê, também, é a questão da sequela, né que você fica trabalhando no meio dos ginecologistas e, o pessoal traz aí. "Ah, sequela, né. O sangramento é por conta da esterilização". Então quando você vai vendo um caso, quando você pega os casos de sangramento, aí você vai ver "Que método utilizou? Fez laqueadura", "Que método utilizou? Laqueadura". Então isso faz a gente pensar na questão, assim, por que tanta esterilização se você pode não ter filhos sem partir pra esterilização, né. E a gente vê, assim... Olha, teve uma que eu fiquei muito... Esse eu fiquei chocada, não esqueço, da história, a menina tinha vinte e um anos, tinha três filhos, já era laqueada, e quando você pergunta pra ela se foi em período eleitoral, sabe. Então algumas coisas que são usadas aí, veio do interior da Paraíba, tá. Então assim, quando você começa a pegar histórias assim não dá pra gente ser tão favorável à esterilização (Íris, enfermeira, 46 anos, trabalha em Hospital, católica praticante).

No discurso de Eufrosina, podemos observar que a lei não somente é datada, pelas transformações sociais gerais ocorridas em nossa sociedade no período, mas igualmente pelas transformações específicas nas relações conjugais em nosso meio que apontam para uma diferença de comportamento sexual e 
reprodutivo entre as classes sociais - enquanto nas classes populares é mais comum ter filhos mais precocemente, nas classes média e alta jovens estão voltados para estudos universitários e projetos de vida futuros, num prolongamento do que se qualifica atualmente como um prolongamento da própria juventude. Nessa perspectiva podemos observar que o discurso de Eufrosina aponta, igualmente, para as mudanças nas relações conjugais contemporâneas e implicações para novos projetos de vida, com novas parcerias quando a mulher, ou o homem, são submetidos a esterilizações precoces, aspectos que os profissionais identificam em sua prática como representando uma maior complexidade para a aplicação da lei da esterilização nos dias atuais. Levanta, finalmente, aspecto, que consideramos importante destacar, relativo à natureza da lei, que deve ser aplicada em todo o território nacional, portanto, para todos os casos de mulheres, homens e casais, em dadas situações previstas independentemente das desigualdades regionais observadas em nosso país. Tal aspecto, que revela a prática da esterilização cirúrgica, prevista na lei, como um problema de Saúde Pública, antes que um problema relativo à esfera da prática médica propriamente dita será reconhecido igualmente por outros profissionais, em seus discursos, independentemente de suas formações e tipo de serviço onde atuam. Podemos entender que diante de tais aspectos, que revelam a complexidade enfrentada pelo profissional na aplicação da lei, Eufrosina apresenta a ideia de que para aperfeiçoar o texto da lei, os legisladores deveriam ouvir os profissionais que, no seu dia a dia, estão colocando em prática à mesma e, com isso, tem o que dizer e contribuir:

A lei teria que ouvir mais quem tá na base, quem tá ali no dia-a-dia fazendo as cesarianas, fazendo os partos, os partos de risco, que a gente sabe que tem parto de risco até no primeiro filho. Então a lei, as pessoas que fazem as leis também têm que estar mais próximas de quem pratica a ação, né. Então isso é o começo, a gente sabe que toda lei, quando começa, ela tem que ser aperfeiçoada. Infelizmente, demora muito anos, né, pra se aperfeiçoar uma lei, pelo menos é o histórico que a gente tem. É que hoje em dia, também, a população também está mudando, né. A gente sabe, por exemplo, que com 
vinte e cinco anos muitas pessoas estão fazendo faculdade ainda, não estão pensando nem em ter filhos. Então a verdade é que a população está mudando, então essa de vinte e cinco anos acaba atingindo uma população que não tem essa coisa... Muitos, com vinte e cinco anos, estão dependendo de pai, estão morando com os pais, né, então eu acho assim, que de repente essa idade, ela pode avançar um pouquinho mais. Vinte e cinco anos nós temos pessoas muito imaturas ainda, mesmo que tenham dois filhos vivos, né. Muita coisa pode mudar. A gente vê aqui, pela prática, que tem pessoas que depois dos trinta, ainda, "Olha, agora eu vou começar a estudar, eu vou começar a fazer tudo aquilo que eu não fiz", e numa dessa ela pode estar esterilizada e querer fazer tudo aquilo que ela nunca fez, talvez ter um outro companheiro, ter mais filhos, e falar "Hoje eu tô em condição de ser mãe, ou ser pai". Então assim, é claro que uma lei, ela também não pode ser facetada, né, não pode falar "Eu vou fazer uma lei desse jeito, outra desse, outra desse", ela vai tentar abranger, mas eu acho que a gente, como profissional, sempre vai ter que estar avaliando isso. Vinte e cinco anos e dois filhos, será que realmente mesmo a lei garantindo, a gente vai autorizar? Isso que nós temos que ter essa consciência, mas aí nós sabemos que vamos enfrentar a lei, porque a pessoa pode procurar o direito dela. Então assim, é um pouco complicado. Porque a lei, também, ela vai tentar abranger o maior número de casos, né, e a gente sabe que nas populações que não tem essa expectativa de vida, tipo assim, que já sai de casa com dezesseis anos pra cuidar da própria vida, com vinte e cinco muitas já tem mais de dois filhos, até. Então eu acho assim, o importante é a gente estar fazendo esse trabalho na base, de conscientizar as pessoas, os casais, as famílias, participar de um planejamento familiar não significa, necessariamente, fazer uma cirurgia. Participar de um planejamento familiar pode ser coisa do tipo assim... Por isso que eu acho que tem que ter em todas as unidades. Mostrar pros casais jovens, principalmente, que eles podem estar evitando as gravidezes sem método definitivo. (Eufrosina, psicóloga, 54 anos, trabalha em UBS, católica praticante).

O identificado aspecto da generalização da lei relacionado às diversidades regionais, já observados no discurso acima de Eufrosina, encontra-se de maneira explícita, igualmente, no discurso de Hebe, abaixo descrito. Tal fato faz com que 
devamos pensar que ao falarmos em classes populares seja necessário considerarmos, do ponto de vista teórico, que as mesmas possuem condições objetivas de existência e estilos de vida diferentes na Região Sudeste e Região Norte ou Nordeste, por exemplo. Assim, como política de saúde pública o planejamento familiar e, notadamente a esterilização cirúrgica, observamos que os discursos apontam de maneira reiterada para o fato de a esterilização cirúrgica apresentar-se antes como prática social, que prática médica - de natureza simplesmente técnica - em nível dos serviços de saúde, notadamente quando se refere à demanda da população jovem. Uma leitura nas entrelinhas, do discurso de Hebe, deve ser destacada, pela natureza ideológica, ética e mesmo eugênica que a esterilização cirúrgica pode se apresentar em algumas práticas. Isto quando se refere questão da existência - em seu serviço de saúde - de pacientes caracterizados como possuindo um "déficit intelectual muito diminuído" e indaga ao entrevistador: "Nós vamos permitir que ela tenha um filho por ano, né?".

Para Hebe, portanto, diante de tais aspectos acima identificados descritos por nós, falta clareza no texto da lei, e, na falta desta, cada caso é um caso, que relaciona com questões relativas à generalização que uma lei que trata de uma questão complexa como é a esterilização cirúrgica. Daí concluir, em seu discurso, que a lei quando promulgada deveria prever em uma maior autonomia da equipe multidisciplinar para tomada de decisão, tendo em vista sua aplicação. Do discurso de Hebe, assim como de outros profissionais, podemos identificar mais uma vez como, a partir dos discursos colhidos a questão da complexidade da prática da esterilização cirúrgica se revela nas ambiguidades, controvérsias e dilemas nesse tipo de prática profissional, em relação ao texto da lei, apontando para a importância do que os profissionais entendem como flexibilização da mesma.

Eu acho que é na redação da lei, visando sempre assim, como na matemática, dois mais dois nem sempre são quatro né, então, eu acho que tem casos e casos, né. Sempre visando assim, que a equipe multidisciplinar tem que estar avaliando caso por caso e decidir juntos se houver alguma controvérsia a respeito da situação, né. Então assim, tem sei lá, vinte anos, mas tem uma vida sócio-econômica ruim, com cinco ou seis filhos qual que é 
o prognóstico disso, né? Então eu acho que são coisas que a gente tem que levantar a questão. E porque não esterilizar? Têm pacientes aqui, por exemplo, que tem um déficit intelectual muito diminuído. Nós vamos permitir que ela tenha um filho por ano, né? Porque ela tem difícil de compreensão de fazer um método contraceptivo, então porque não laquear? Quer dizer, cada caso é um caso, eu acho que isso precisa ser estudado e todo o contexto desse caso. No sentido assim, que os casos têm que ser estudados pela equipe multidisciplinar e essa equipe multidisciplinar é que vai decidir. Sim, porque a gente tem que pensar que essa lei, ela não é válida, por exemplo, só pra cidade de São Paulo ou só pro Estado de São Paulo, nós estamos falando de Brasil, então quando a gente fala de Brasil eu não posso me basear na cidade de São Paulo, os profissionais da cidade de São Paulo com os profissionais do restante do Brasil. Então acho que tudo isso tem que ser levado em consideração. Então eu tenho que pensar no cara que tá lá no alto Amazonas, lá no meio daquela Floresta Amazônica, que vai pegar a lei e ler, porque se a minha... Se uma paciente, né, se uma cidadã aqui da cidade de São Paulo tem o direito, aquela que mora lá no meio da Floresta Amazônica também tem, e quais são os profissionais que estão lá? Então eu acho que a lei tem que estar clara pra todo mundo, isso com certeza, mas que ela não pode ser assim, totalmente ao pé da letra. Eu acho que tem que tá, hã... A decisão tem que estar na equipe multidisciplinar visando todos os fatores, né, todo o contexto daquele cidadão. Que a equipe multidisciplinar pode decidir a respeito da lei, por exemplo. (Hebe, enfermeira, 46 anos, trabalha em UBS, espírita praticante).

No discurso de Graças mais uma vez, a exemplo do observado nas falas anteriores de Hebe e Eufrosina, observamos a colocação da questão da generalização da lei, como política de saúde pública, frente à tradição da prática médica que deve analisar, caso a caso, decisões para pacientes em intervenções como a esterilização cirúrgica. Aponta problemas para a implementação da Lei quando menciona que a falta de clareza do texto prejudica o usuário, pois, ocorrem casos em que a esterilização cirúrgica é aprovada pela equipe multidisciplinar, mas o mesmo retorna à Unidade Básica de Saúde sem ter feito o procedimento por discordâncias dos profissionais em sua execução. Tal fato 
permite-nos inferir, ao menos em alguns serviços, a existência de uma falta de articulação entre diferentes equipes envolvidas na aplicação da lei, uma vez que, conforme observamos pelos discursos já analisados em itens anteriores, existe uma dissociação entre o processo de aprovação e de execução da esterilização cirúrgica. Em termos da identificação de tornar a lei mais flexível a lei, o discurso de Graças aponta para a questão da idade, assim como da restrição da laqueadura no momento do parto:

Eu acho que ela deveria ser mais clara. Eu acredito que assim, você teria que tá colocando, não uma idade específica, explicando sim, que pela idade você corre riscos se for muito nova. Eu acredito, sim, a pessoa é muito nova e corre riscos na saúde, ponto. Mas há casos e casos. Eu acho que deveria... Tem que ser colocado de uma forma que não enquadre que não deixe fechado. Teria que ter uma flexibilidade. Deveria ter um artigo que, por exemplo, haja casos, algumas exceções poderiam ser feitas, né, pra tá... Não enquadrar, que pra mim está enquadrado. Para maiores de vinte e cinco anos ou, pelo menos, com dois filhos vivos, né. Então assim, a gente já mandou casos que são menos de vinte e cinco anos, com mais de dois filhos vivos, e retornou porque não foi aprovada, então a gente acredita que é pela idade, também, que eles se pegam sobre isso, né. Então pra fazer de uma forma que não se enquadre né, que deixe uma forma flexível de entendimento, que a gente possa tá trabalhando e tá orientando mais a população a esse respeito. Outra alteração seria em relação à restrição no momento do parto. E que também, a gente vendo pelo lado médico, né, pro lado médico também não é, vamos colocar entre aspas, não seria justo por que você estaria contrariando uma lei, né, e a gente sabe os casos e problemas que tem com o profissional que contraria uma ética médica ou uma lei médica, vamos supor. Mas que seriam você, como profissional médico, a partir do momento que você se forma, você faz um juramento que você, acima de tudo, você tem que primeiro pensar no paciente, e se naquele determinado momento o paciente, você acredita que seria o melhor pra ele, então você tá desrespeitando uma lei. Então por isso que eu acredito que nessa lei deveria ter uma flexibilidade maior com relação a este caso, também, pra que vocês, médicos, possam estar mais embasado por esta lei, não sendo contrariado por ela (Graças, psicóloga, 28 anos, 
trabalha em UBS, católica não praticante).

Para Deméter, a falta de clareza no texto da lei traz ambiguidades, contradições e dilemas para a decisão dos profissionais, quanto à aprovação ou não da esterilização cirúrgica tende em vista a especificidade de cada caso, notadamente diante de questões clínicas envolvidas no processo de avaliação. Entende que deveria estar definida, no texto da lei, uma idade mínima, que sugere deva ser vinte e um anos, considerada a maioridade civil. Entende, igualmente, que a esterilização deveria também ser permitida no momento do parto, mesmo sem cesáreas sucessivas anteriores, pois na sua avaliação, o aumento da taxa de cesárea independe da lei 9263/96:

Eu acho que a lei foi o início. Tem algumas coisas que precisam ser em minha opinião, readequadas, melhoradas, né, mas eu acho que, a princípio, é uma lei boa. Com algumas pequenas mudanças, é uma boa lei. Eu acho que tem alguns pontos que precisariam ser um pouquinho mais detalhados, né, que dão margem à confusão. Então talvez se tornar um pouco mais clara, né, os dezoito anos e pelo menos dois filhos, ou vinte e cinco anos, mesmo sem filhos, então eu acho que isso precisaria estar mais esclarecido na lei, porque dá muita margem a dúvidas e a interpretação duvidosa. É eu acho que deveria ficar mais claro, dezoito anos, talvez aumentar um pouquinho essa faixa etária pra vinte e um anos, né, quando você imagina que a pessoa já tenha um pouquinho, um maior grau de discernimento, né, e acabar com essa hipocrisia, porque assim, a gente não viu reduzir o número de cesáreas por conta das laqueaduras, e têm pacientes que você pode, ou estipular em que casos você pode fazer durante a cesárea, mas não vetar totalmente e só colocar a laqueadura com risco de vida materno e fetal. Eu acho que tem algumas coisas, como eu já te falei, que precisam ser modificadas, né. Por exemplo, uma das coisas que eu acho que precisa ser modificada é o fato de você só poder fazer laqueadura em cesáreas anteriores, né, porque aí se subentende que sejam duas. Há pouco tempo atrás, mesmo, eu tive uma paciente de trinta e nove anos, um diabetes gestacional leve, com cesárea anterior, acabou tendo um sofrimento fetal e foi pra segunda cesárea, e eu não pude fazer uma laqueadura, embora ela quisesse, por estar fora do protocolo. Então eu abri, fiz uma nova cesárea, 
não era risco de vida materno e não era risco de vida fetal, mas era uma paciente de trinta e nove anos. Então ela tem uma chance maior de ter má formação na próxima gestação, mas não que obrigatoriamente vai ter né, ou seja, não é nem risco de vida materna, nem fetal, mas eu acho que é uma paciente extremamente consciente e que poderia ser feita uma laqueadura. Como a lei vê nesse sentido, assim, não vamos fazer a cesárea pra fazer laqueadura, pra reduzir o número de cesáreas, a gente não viu que isso ocorreu, o número de cesáreas continua elevado. $E$ as pacientes que realmente tem indicação, né, que poderiam ser beneficiadas durante $o$ ato cirúrgico, não podem ser beneficiadas. Então eu acho que isso é uma coisa que precisa ser mudada. (Deméter, médica, 55 anos, trabalha em UBS, católica não praticante)

Segundo relato de Agalaia, psicóloga, observamos que a questão da flexibilização da lei está igualmente presente nos discursos dos profissionais, mas adquire, em sua proposta, uma maior amplitude, uma vez que entende que a lei deveria definir tão somente a idade mínima de 21 anos, considerada a maioridade civil, sendo que os outros requisitos a serem decididos ficariam a critério da equipe multidisciplinar tendo em vista a necessidade de individualizar caso acaso.

É eu acho que essa lei já tem mais de dez anos e a sociedade mudou nesses mais de dez anos. Eu acho também que a área da saúde, a área médica evoluiu muito também nesses últimos dez anos. Eu acho que a esterilização cirúrgica não é mais barganha política, não é mais controle de natalidade, controle demográfico, como era antigamente, então eu acho que a lei tem que ser revista, sim, né. Eu acho que ela tem que ser ampliada, né, ela tem que ser... Ela tem que dar um pouco mais de autonomia pra equipe de saúde, individualizando os casos. É eu acho que contemplar no momento do parto é uma necessidade hoje, né, de saúde pública, uma necessidade da mulher, do casal, né. Eu acho também que ampliar um pouco esse parâmetro dos vinte e cinco anos ou dois filhos. Eu acho que ampliar um pouco a...

Eu acho que eu colocaria como idade mínima vinte e um anos, tá. A partir daí eu acho que seria avaliação a critério médico e também a critério da assistente social ou do psicólogo, né. Eu acho que ter filhos é um desejo de algumas mulheres, não é um desejo de todas as mulheres como todo mundo 
imagina né. E também ficar tomando contraceptivo hormonal ao longo dos anos pode não ser uma opção dessa mulher. Então eu acho que cada caso tem que ser avaliado. Essa ideia da lei de que dois médicos devem avaliar eu acho interessante, eu acho que tem que ser, não sei se dois médicos, mas talvez o médico e um outro profissional de saúde, né, então eu não limitaria, talvez, ao número de gestações ou a idade, né. Eu acho que a gente tem que individualizar, eu acho que a gente tem que dar o direito a todas as mulheres a partir de vinte e um anos, mas sempre com o trabalho educativo antes. Eu acho que as mulheres têm que receber informação, eu acho que elas têm que ser orientadas, elas tem que avaliar toda a condição pra elas poderem optar por uma esterilização cirúrgica, mas eu acho que isso tem que ser aberto a todas as mulheres e todos os homens a partir de vinte e um anos (Agalaia, psicóloga, 52 anos, trabalha em Hospital, evangélica praticante).

A questão da necessidade de flexibilização da lei coloca-se, igualmente, na fala de Apolo. Para esse profissional, devido à falta de exceções na lei, notadamente em relação à questão da idade mínima, mas, igualmente, em relação a outros aspectos que envolvem a prática médica relacionada à esterilização cirúrgica. Isto porque a aplicação da lei não permite contemplar diferentes situações que podem estar presentes no processo de execução do procedimento, sem que o profissional tenha "garantias" da avaliação do caso por se tratar de um processo complexo, mas realizado de maneira fragmentada, no qual diferentes equipes e profissionais atendem sem uma necessária articulação. Uma questão presente no discurso de Apolo, que merece destaque, refere-se à recomendação presente na lei para o desencorajamento da esterilização precoce, por parte da equipe. Pelo que podemos depreender tal prática fica prejudicada se for da responsabilidade do médico, uma vez a mesma envolve um processo de orientação específica por parte de outros membros da equipe, para a existência e oferta de outros métodos contraceptivos via estratégia de planejamento familiar, o que implicaria uma melhor definição de divisão de trabalho por parte dos diferentes profissionais. 
Mas eu acho que o critério que foi usado, ele atende algumas regiões e não atende outras, principalmente no fato da idade, né. Porque aqui no sudeste, e talvez no sul, a realidade social de vinte e cinco anos é muito diferente da realidade social, tanto na paridade quanto na perspectiva profissional, em uma série de coisas que não são médicas, né, e que eu acho que são diferentes. Então eu acho que isso é... Ela teria espaço pra uma mudança. E a outra é na redação, que eu ainda acho que ela é uma redação, principalmente nesse artigo dez, aqui no parágrafo primeiro, né, que ele determina, mas ele não dá nenhuma brecha das exceções, aqui, que você tem, tanto pro bem quanto pro mal. Mas o desencorajar, às vezes, fica na responsabilidade do médico, de fazer ou não. De forma, assim, muitas vezes imediata. Quer dizer, às vezes eu tenho quinze minutos, às vezes, da hora que eu conheço a paciente, que ela chega com uma carta de laqueadura, eu tenho que tomar uma decisão que, às vezes, ficou ou não ficou claro, de alguém que acompanhou durante o pré-natal. Então eu acho que é uma situação específica. Eu acho que aqui mereceria alguns subitens, né. Se a paciente faz pré-natal com o mesmo médico que faz o parto tem essas atenuantes e esses agravantes. Se a paciente faz o pré-natal com um médico e depois é atendida por outro na hora do parto, eu acho que têm agravantes e atenuantes. Então eu acho que a lei, ela foi um avanço, mas ela colocou, assim, coisas diferentes numa mesma sacola, numa mesma situação. Eu acho que a gente tem que considerar a lei como um avanço, Sérgio, certo? Então eu acho que isso é significativo. Agora, ela vai precisar de alguns ajustes ao longo do tempo aí.

(Apolo, médico, 57 anos, plantonista, católico praticante).

Nos discursos de alguns outros profissionais, 0 considerado aperfeiçoamento da lei apresenta-se de maneira mais explícita no sentido da mudança do artigo 10, relativo à definição, em seu texto, do critério de 25 anos ou pelo menos dois filhos vivos para 25 anos e dois filhos vivos, para a realização da esterilização cirúrgica, além da necessidade de ser retificada a restrição da esterilização nos períodos do parto e puerpério presente no artigo 10, Inciso II $\S$ $2^{\circ}$, uma vez que tal restrição coloca limites à prática médica em detrimento da própria paciente. 
Eu acho que mudaria essa questão de é vetado durante processos de períodos de parto e aborto, e cesáreas sucessivas anteriores eu acho que eu colocaria "Ou pacientes que já tenham participado de todo o processo, amparado dentro dessa lei", né, então eu deixaria uma coisa clara dizendo que se a mulher chegasse numa situação dessa poderia ser feito, pra respaldar o profissional que tá fazendo, entendeu? Então eu mudaria, eu acrescentaria aqui. E em relação aos vinte e cinco anos ou pelo menos dois filhos vivos. É difícil dizer. Porque eu, sinceramente, eu acho que... Eu sempre questionei, porque eu acho que deveria ser de 25 anos e dois filhos vivos e não o (Hera, enfermeira, 42 anos, trabalha em UBS, evangélica praticante).

Ah, essa aqui de vinte e cinco anos ou pelo menos com dois filhos vivos. Isso aqui é meio polêmico, porque senão a pessoa com dezoito anos, vinte e um anos pode querer, também, fazer laqueadura. Manter os vinte e cinco anos e dois filhos. Agora, tem as exceções, HIV, né, de repente se a pessoa tem um problema de saúde muito sério, outros problemas de saúde, então eu acho que tem que tá na lei, dependendo do problema de saúde da pessoa que... Eu mudaria. No caso de indicação médica pra uma cesariana, uma vez aprovada essa laqueadura, também poder fazer na hora do parto. $E$ a laqueadura pós-parto que se fazia antes da lei, que é a incisão peri umbilical, né, acho que deveria ser realizado. Ah, eu acho. Porque é o que nós comentamos, a mulher tem o bebê e depois pra ela retornar é muito mais complicado pra ela, pro serviço é mais custo para o serviço, pra mulher fica mais difícil. E o que acontece no nosso serviço? A mulher acaba deixando, deixando, e volta grávida de novo. Então deveria fazer logo após o parto, sim (Nêmesis, enfermeira, 52 anos, trabalha em Hospital, católica praticante).

Eu acho que nesse caso exclusivo, nesse último caso, eu acho que teria que ter alguma mudança, mesmo. Mas pra que isso tenha, teria que ter na reuniões com os profissionais que estão envolvidos, se há, realmente, essa necessidade. Eu acho que tem que ter um movimento mesmo, das políticas, né. Então esta redação que proíbe no momento do parto, Eu acho que pode ser revista, né. Porque é um caso que, realmente, você tá com um documento assinado pela paciente, no momento ela fala que ela concorda 
só que, realmente, a lei não permite. Então eu, como eu não sou médica, assim, eu acho que culturalmente a paciente não iria processar, futuramente, mas aqui na lei se abre a margem aí pra um futuro processo. Eu não faria. Em relação a vinte e cinco anos ou pelo menos dois filhos vivos, Na minha forma de interpretação é vinte e cinco anos, a idade mínima, pelo meu entendimento, abaixo de vinte e cinco anos, ela está impedida. Eu entendo isso. Eu acho que esse ou, ele abre muito, né. Eu acho que poderia, sim. caberia uma modificação Porque aí... Porque aí o quê que acontece? Pra nós aqui, pelo que eu trabalhei aqui na área, a gente vai mesmo pela coisa clínica, então esse ou, pra mim também dá margem a justamente essa parte da paciente, a parte mais clínica, né, e aí com dois filhos vivos. Então é complicado, porque pode ser que seja uma paciente com vinte anos, mas ela não pode ter mais filhos, ou por diabetes, ou sei lá, pela condição. (Tália, psicóloga, 46 anos, trabalha em Hospital, católica praticante).

Primeiro eu acho que ele [o texto da lei ] deveria ter sido discutido entre as instituições que poderiam fazer, tá, todas aquelas ligadas ao Sistema Único de Saúde, né, pra que houvesse um consenso único. E segundo, eu acho que tem que tirar o ou do artigo dez, eu acho que é e pelo menos dois filhos vivos. Isso é a minha opinião, pessoal, tá? E o fato de você não poder fazer em pacientes com uma... Com cesárea, uma cesárea só, também eu acho que isso dificulta um pouco o dia-a-dia da, da, da... Da paciente que dá à luz. Eu modificaria que os pacientes pra fazer, pra ser submetidos à esterilização deveriam ser maiores de vinte e cinco anos e dois filhos vivos. Eu acho que seria um grande avanço, tá. Além de tudo, eu faria um texto permitindo que se faça durante os períodos do parto, tá, contanto que houvesse uma regulação pra isso. Porque eu acho que facilita você internar o paciente, fazer o parto, parto normal, tá, e, no dia seguinte, como era feito no passado, você fazia no dia seguinte [a esterilização] com o bebê internado e, com isso, você estaria estimulando o aleitamento, a continuidade ao aleitamento materno (Dionísio, médico, 50 anos, plantonista, espírita praticante).

Para Erínias, a lei deveria sofrer mudanças apenas quanto ao critério do número de filhos, sendo que a questão da idade deveria ser flexível, caso a caso. Destaca aspecto importante relativo ao fato de profissionais envolvidos na 
aplicação da referida lei não terem o treinamento adequado, com reciclagens periódicas, além da menção à falta de recursos humanos para essa atividade em saúde. Em seu discurso, igualmente, fica a observação quanto à importância de se repensar critérios de inclusão de mulheres e homens no programa de planejamento familiar, em nível dos serviços de saúde, voltado a casais, mulheres ou homens com filhos, uma vez que o planejamento familiar deveria para Erínias, com o que concordamos ser iniciado antes de se conceber qualquer número de filhos:

Quanto ao artigo dez eu acredito que ela [a lei] possa ser repensada e modificada. Quanto à idade mínima eu gostaria de alterar, não pra dois filhos sem mencionar a idade. Eu acredito que dessa forma está muito polêmica e gera um conflito, entre até a questão ética do profissional e o atendimento, que é o usuário que exige o cumprimento da lei. A lei, ela me parece que contempla o necessário, só precisa ser cumprida pelo Estado. O Estado não fornece materiais educativos e nem treinamento pros profissionais. Inclusive eu, tô precisando de muito treinamento. Depois que eu acabei dando uma relida nessa lei, verifiquei que faltam esses treinamentos fora do hospital, uma reciclagem pros profissionais e uma reunião multi profissional para que nós tenhamos mais atualizações dos métodos recentes, que chegam, né, e esse fornecimento de métodos pelo governo que é precário. Eles fornecem, nem dez por cento do necessário. Então falta recursos humanos, treinamento e material. E quanto à Unidade Básica, também, um melhor treinamento dos profissionais, melhor inclusão do atendimento preventivo, que é o mais importante. Antes do casal, pensar em ter filhos o planejamento familiar já deveria estar entrando e iniciando essa vida desses casais, porque quando... Os pacientes que chegam no nosso atendimento com alguns abortos, eles têm uma chance, como eles não têm filhos, de entrar nesse planejamento. Eu verifico a dificuldade deles na Unidade Básica, pra inclusão, porque os profissionais normalmente abordam esses usuários e colocam que eles não têm filhos e que eles não poderiam estar entrando aí no planejamento. Então, pra mim, em minha opinião, o planejamento é antes

de você ter qualquer número de filhos. É um processo educativo, lento e importante (Erínias, assistente social, 50 anos, trabalha em Hospital. evangélica não praticante). 
Diferentemente de Erínias, Calíope sugere uma idade mínima de 25 anos defendendo a ideia de que o número da prole é que deveria ser flexível. Defende a flexibilidade da lei, igualmente, em relação à realização da esterilização no momento da cesárea destacando, ainda, que a autonomia da usuária deveria sempre prevalecer sobre a opinião dos médicos:

Eu entendo que sim, que, no texto da lei, mulheres a partir de vinte e um anos, elas teriam [direito]... É... Com dois filhos ou mais ela teria direito. $E$ o que eu acho é que, talvez emocionalmente, vinte e um anos seja muito precoce, mas se a gente for olhar do ponto de vista financeiro e social, talvez a lei não seja tão absurda assim. Então conforme eu fui trabalhando ao longo dos anos e entrando em contato mais com o dia-a-dia, com a vida das pacientes, com a realidade de cada uma, eu passei a achar que talvez essa idade não seja tão precoce. Mas, mesmo assim, continua me preocupando a imaturidade emocional, que eu acho que talvez algumas tenham insegurança... Em ter uma, uma decisão tão importante com essa idade, mesmo porque muitas, apesar de ter um estado conjugal, naquela ocasião estável, pela própria idade a grande maioria vai mudar o estado conjugal e existe uma, eu acho que uma grande possibilidade de algumas delas, inclusive, mudar de ideia e querer reverter uma esterilização definitiva.

Se eu for pensar como sendo... Que ela é subordinada e tenta regulamentar algo que vem da constituição e que não era regulamentado eu acho, sim, um avanço. Agora, eu sou a favor da laqueadura ser mais liberal e que a paciente, sim, ela precisa ter acesso a todos os outros, mas que não teriam esses critérios tão rígidos. Eu acho que... Eu acho assim, que ela deveria ter acesso a todos os outros métodos. Sim, ser informada de tudo, ter esse acesso, passar com o psicólogo e tudo, mas que ela deveria...ter autonomia. Não precisaria passar sob o crivo de médicos pra decidir se a opinião dela deve ser acatada ou não.

É eu acho que... Como que eu acho que seria o ideal, no meu parecer: uma paciente, sei lá ou por indicação do vizinho, enfim, ela chegar ao serviço solicitando a laqueadura, eu acho que ela deveria ter... Passar como passa agora. Ter a solicitação, passar com o assistente social, passar com um psicólogo, ter acesso aos métodos, todo mundo explicar, tudo como acontece agora, mas ela... Chegou a última lá, a última instância, e ela 
colocou que não, que ela quer mesmo a laqueadura, pronto, que isso fosse seguido e não avaliado por profissionais médicos pra ver se isso deveria ser acatado ou não.

Então, primeiro eu acho... Como o caso desse último, que tem alguns casos em que não justifica ela ser novamente submetida ao procedimento, então a gente já poderia fazer o procedimento nessa cesárea. Eu sei que a preocupação do governo ou de quem regulamentou é na tentativa de evitar que se faça cesárea só por essa indicação, mas eu nem sei se teria como resolver isso, mas eu acho que isso é um ponto que teria que haver uma tentativa de melhora. E quanto à idade eu acho que vinte e um anos é muito precoce, mesmo sabendo que hoje elas iniciam a vida sexual ativa muito precocemente e que aqui tá descrito vinte e um anos com dois filhos vivos, mas é muito comum a gente ver pacientes até com maior número de filhos nessa idade. Mas eu acho que vinte e um anos é muito precoce, emocionalmente, pra ter uma decisão assim, tão definitiva.

Ah, idade mínima eu acho que acima, pelo menos, de uns vinte e seis anos, vinte e cinco anos. Não, eu acho que mais de dois filhos não. Eu acho que vinte e cinco anos, mas dependendo da situação conjugal e financeira eu acho que um filho é suficiente se ela quisesse fazer uma laqueadura. Dependendo... Como eu falei, elas iniciam muito precocemente, então eu acho que atualmente uma paciente que... Uma mulher que chega até os vinte e seis, vinte e sete anos, e que só, até ali ela só teve um filho, eu acho que isso deve ter sido uma escolha, ela deve ser uma paciente que já faz planejamento familiar há algum tempo, então eu acho que um filho pra ela seria suficiente, se fosse a escolha dela (Calíope, médica , 38 anos, trabalha em Hospital, espírita não praticante).

Láquesis, em seu discurso, assim como outros profissionais, sugere a necessidade da definição de uma idade mínima, considerando a ambiguidade presente do texto da lei, independentemente do número de filhos, pois considera que, na perspectiva dos direitos reprodutivos, ninguém é obrigado a ter filhos. Defende, também, a realização da laqueadura logo após o parto normal, como era realizada no passado, para aproveitar a internação, destacando a importância principalmente nos casos das populações mais carentes, dada a necessidade de 
retorno em dois meses para poderem realizar a esterilização com nova internação. Destaca ainda a questão da capacidade civil plena e aborda questão polêmica, sobre a esterilização em pacientes psiquiátricas que, na lei atual, considerada por ela restritiva nesse aspecto, depende de uma autorização judicial dificultando a realização do procedimento:

Algumas coisas... Algumas coisas do texto da lei eu acho que elas são um pouco... Não são tão claras e algumas, elas dificultaram a vida das mulheres, notadamente das mulheres pobres, tá. Então, por exemplo, no caso de pacientes psiquiátricas. Anteriormente a 1996 praticava-se a laqueadura em mulheres psiquiátricas desde que ela tivesse um laudo psiquiátrico, entendeu, dizendo que era uma paciente que tinha um risco de suicídio. Enfim, ela tinha uma avaliação médica e se praticava. Atualmente, as pacientes num quadro psiquiátrico a gente tem que, no texto da lei, nós deveríamos pedir autorização para o Ministério Público, então nós temos muitos casos de pacientes que estão nessa situação. Então dificultou muito pra essas mulheres. Eu acho que esse ponto da lei dificulta. Um dos pontos da lei que eu também considero que dificultou a vida, principalmente das mulheres pobres, é a não permissão da laqueadura puerperal.

Então, um dos pontos que eu considero, também, que dificultaram, é a questão da laqueadura puerperal. Pra quem trabalha, trabalhou ou trabalha nas periferias de São Paulo, a gente sabe que é muito difícil a mãe deixar essas crianças em casa, se internar após sessenta dias pra fazer essa laqueadura. Então esta mãe pobre, ela fazia a laqueadura puerperal, era uma internação. Ela internava, vinha, nascia e fazia imediatamente a laqueadura nela. Não poder fazer a laqueadura puerperal penalizou essas mulheres. O texto da lei foi pra evitar que se fizesse cesárea pra se fazer a laqueadura, mas isso atingia as pessoas de classe média, as pessoas que tinham poder aquisitivo maior, e acabou prejudicando as pessoas com baixo poder aquisitivo. Então essa parte do texto da lei eu acho que também é bastante... Você não poder fazer a laqueadura puerperal eu acho que dificultou pra essas mulheres, tá. Dificultou, além do que, muitas delas não vão parar de amamentar, porque elas ficam com a autorização da laqueadura na mão e ficam desesperadas pra fazerem a laqueadura, e nesse meio tempo elas podem engravidar novamente. Então eu acho que isso dificultou, sim. Para as pessoas de menor poder aquisitivo, dificultou. $A$ 
lei dificultou. Eu modificaria esse pedaço do texto da lei. Outra coisa na lei: é dúbio quando você diz "vinte e cinco anos", "que tenha vinte e cinco anos ou dois filhos", entendeu? Então alguns profissionais interpretam que são vinte e cinco anos com dois filhos, outros interpretam que você tendo dois filhos ela pode fazer a qualquer momento. E aí como é que você faz com o menor de idade? Então eu acho que nessa parte o texto da lei não é muito claro, ele deixou a desejar. A gente sabe que tem estudos mostrando que a maior faixa de arrependimento é entre vinte e cinco e trinta anos, né, então eu acho que ficou meio dúbio aí o texto da lei, tá?

E/ou. Ou você diz o seguinte: "Olha, as pessoas acima de vinte e cinco anos, elas podem fazer laqueaduras, independentemente do número de filhos que elas tenham" ou "As pessoas com dois filhos, elas podem fazer laqueadura". Agora, eu deixaria claro no texto que essas pessoas, elas deveriam ter... Não poderiam ser menores de idade. Não fica claro isso. Um menor de idade, com dezessete anos, que tenha três filhos, você poderia fazer laqueadura, porque ele está emancipado por lei. Ele poderia fazer. Eu colocaria uma idade mínima. Eu colocaria uma idade mínima, independentemente do número de filhos, estado conjugal...

Então o texto é obsoleto. As mulheres não vão mais poder fazer laqueadura? As que tiverem um filho. A mulher tem trinta anos e ela não quer mais ter filhos, ou ela tem, ela teve aquele filho só e ela não quer mais, é um direito dela. E aí? Nós não vamos fazer mais? Eu interpreto como ela ...... Ninguém diz quantos filhos a pessoa pode ter. Porque que eu tenho... Uma pessoa que não tem filhos, ela pode ser obrigada a ter? Eu queria saber..(Láquesis, médica, 55 anos, plantonista, católica não praticante).

No discurso de Zeus, encontra-se presente, igualmente, como no de Láquesis, a preocupação com a esterilização em pacientes psiquiátricas. Diferentemente de Láquesis, sua concepção é em relação à permissividade de retirar a vida reprodutiva dessas, preservando a família de gravidez indesejada, o que poderia ampliar, com a esterilização, sua condição de vulnerabilidade, na medida em que mulheres nessas condições permaneçam vítimas de violência sexual. Ressalta, como Láquesis e outros profissionais, as vantagens da laqueadura pós-parto normal, proibida pela lei vigente. Os argumentos 
apresentados pelo profissional permite-nos observar em que termos a questão da lei da esterilização, como política de saúde pública, coloca dilemas ao exercício da medicina como atividade de âmbito coletivo, por colocar limites e critérios à sua autonomia de decisão. Essa questão do dilema mais uma vez se apresenta quando manifesta dificuldade em avaliar novos parâmetros a serem colocados em relação à idade e número de filhos, tendo em vista o contexto de transformações em nossa sociedade, sugerindo a possibilidade de uma idade mínima de cerca de 30 anos para a realização da esterilização cirúrgica:

Existem alguns pontos desse texto que me parecem... Eles, enfim, eu não acho que eles sejam o ideal. Especificamente, eu sempre cito a questão de proibição da realização no período peri-parto e pós-parto imediato, porque tirou das equipes de assistência médica a oportunidade de realizar uma técnica de esterilização, que é a técnica através de incisão peri-umbilical, que poderia ser realizada em vários pacientes e que, hoje em dia, só pode ser realizada em condições especiais estabelecidas pela Portaria 48 da SAS, de mil novecentos e noventa e nove, uma vez que como você tem no texto a proibição de se realizar no período peri-parto ou pós-parto imediato, exceção feita às pacientes submetidas a cesáreas anteriores, você excluiu um grupo relativamente grande de pacientes que poderia se beneficiar. Então esse aspecto técnico, ainda que ele tenha atrelado uma intenção boa, que é a de tentar evitar a realização de cesáreas desnecessárias para, exclusivamente, a realização da laqueadura, mas eu acho que é um texto que precisaria ser repensado. Então eu não gosto dessa questão no texto. Outra coisa que eu não gosto do texto é a possibilidade de você esterilizar indivíduos que são considerados legalmente incapazes. Quer dizer, existe uma parte dela que diz que, graças a uma definição judicial, existe a possibilidade de se esterilizar um, um... Enfim, uma pessoa no Brasil que não tenha capacidade civil plena. Isso, pra mim, é muito complicado porque, em geral, está atrelado a situações de risco de mulheres submetidas à violência sexual e que não tem condições de se proteger, e na hora que o Estado oferece essa possibilidade pra família, de esterilizar uma moça desse tipo, e que vai tirar, portanto, da família o ônus de eventuais gestações indesejadas, eu fico imaginando se não vai expor essas meninas, essas mulheres, a uma manutenção dessa situação de risco. Ou seja, a partir do momento que eu 
tenha uma menina deficiente que alguns... Que é alvo de violência sexual e que é interesse da família que ela não engravide, a hora que eu permito a esterilização eu vejo, em muitos casos, quase que uma liberação pra que ela continue sendo vítima de violência sexual. Então eu acho que essa é uma parte do texto que deveria ser repensada, porque deveria haver, antes de tudo, uma preocupação em proteger essa mulher, e não em simplesmente retirar a condição reprodutiva dela, facilitando, inclusive, pra que a família afrouxe um pouco os cuidados que ela deveria ter.

Esse é, talvez, o ponto principal pra mim. Ou seja, há que se reconsiderar a possibilidade de realização do procedimento no período de puerpério imediato, seja durante uma, uma, um parto cesáreo, seja no pós-parto vaginal que você tá... Tenha condições de fazer isso através de, ou incisão peri-incisional, ou mesmo através de laparotomia, aproveitando o procedimento anestésico e porque a questão da cesárea, de não estimular a realização da cesárea, não me parece que tá sendo resolvida por esse tipo de atitude. Quer dizer, eu vejo com muita desconfiança essa boa intenção do legislador, no sentido de não estimular a cesárea para a realização de laqueadura, mas eu acho que ela é uma medida ineficaz e, portanto, eu acho que deve ser repensado o texto no sentido de que a gente tenha um leque mais amplo de possibilidade de realização do procedimento, já numa primeira ou segunda cesárea, ou por incisão peri-umbilical, ou por laparotomia no pós-parto vaginal, imediato, porque muitas pacientes são prejudicadas, são obrigadas a retornar à instituição depois de quarenta e dois, quarenta e três dias para a realização do procedimento, e a lei pressupõe uma má intenção por parte do obstetra, no sentido de indicar a laqueadura, de indicar o parto cesáreo só pra laqueadura. Isso não é verdade. Existe esse problema? Existe, mas a gente for avaliar, eu não tenho dúvida que a maior parte das indicações de cesárea, no Brasil, hoje em dia, tem absolutamente nada a ver com uma laqueadura, e consequentemente, não me parece que punir algumas pacientes que poderiam se beneficiar do procedimento nesse momento, seja o de interesse pra população em geral.

Eu não tenho como... Eu até considero os dois filhos como sendo um número razoável, não tenho como estabelecer um número que eu possa considerar ideal, isso já é uma questão muito pessoal, educacional, formação, de tipo de família que as pessoas têm etc, então eu não me 
arriscaria a definir isso. A idade, também é um parâmetro, pra mim, muito complicado. Vinte e cinco anos na população atual, principalmente do ponto de vista da mulher que tá postergando o início da sua prole, é uma idade que não me parece um absurdo, mas que tem que ser melhor discutida. Eu acho que eventuais atrasos, entre aspas, ou seja, eventuais elevações desse número pra algo em torno de trinta anos me parece ser um pouquinho mais condizente com a realidade do país, mas eu confesso que eu não tenho... Eu tenho dificuldade de avaliar esses dois parâmetros. Quer dizer, são questões muito pessoais e, portanto, não sei se é possível chegar a um consenso que atenda, até o interesse da população como um todo, uma vez que é uma lei que vai ser aplicada pra todo mundo (Zeus, médico, 51 anos, trabalha em hospital, não é adepto a nenhuma religião).

Os discursos de Eros e Ares, a seguir, a exemplo do observado em Zeus, retrata como a questão dos diferentes critérios para a esterilização colocam dilemas diferenciados à prática médica em saúde pública, por não se restringir somente a decisões estritamente clínicas. Nessa perspectiva podemos observar no discurso de Eros, sua crítica ao texto da lei que representou, na sua avaliação, um retrocesso por representar uma liberalidade às mulheres e homens, não existente antes, com implicações futuras não somente na esfera pessoal, mas igualmente, em relação a efeitos colaterais do procedimento, levando a sequelas como dores pélvicas. Acredita que o avanço da lei seria o de sua revisão, fundamentada em amplo debate tendo em vista embasá-la de maneira sustentada, considerando a importância do aspecto multidisciplinar envolvido. Na sua visão, o direito à esterilização deve relacionar-se com a questão clínica, por considerar que o maior direito é o direito à vida. Quanto à idade mínima e número de filhos para a autorização à esterilização, sua proposição é a de que deveria ser de 30 anos com 3 filhos, e não somente dois. Para Ares, esse critério deveria contemplar trinta anos, com dois filhos, por considerar que realizada precocemente, como permite 0 atual texto da lei, a esterilização representa uma agressão ao corpo da mulher. $\mathrm{Na}$ mesma perspectiva de Eros e Ares, médicos, relativiza os direitos de mulheres, homens e casais previstos pela lei, destacando, sobretudo, o que poderíamos 
sinalizar como uma discriminação de gênero quando afirma, por exemplo, que não é pelo fato de a mulher desejar que a esterilização deva ser aprovada pela equipe ou realizada pelo médico, uma vez que tal fato abriria espaço para uma liberação da mesma que a tornaria vulnerável notadamente às doenças sexualmente transmissíveis, incluindo o HIV.

Pra mim a lei foi um retrocesso. Retrocesso, porque assim, porque eu acho que passou a se permitir o que a gente não permitia e essa liberalidade, eu sou contra. Então pra mim, havendo essa liberalidade toda, e com tanta... Com tantos problemas que vem em decorrência disso, como eu disse, não só de arrependimento, mas pacientes que têm algias pélvicas. Você sabe disso, você faz ambulatório de algia pélvica e você sabe totalmente disso. Então, que não leva em conta a, vamos dizer assim, os efeitos colaterais do procedimento, as seqüelas vamos dizer, assim, se pode considerar como uma sequela, eu acredito que sim. Então que não leva isso em consideração, então eu acho, eu volto a dizer que eu acho esse estudo, o estudo que levou a essa lei muito mal embasado, então eu não acho que houve avanço nenhum. Eu acho que o avanço seria, realmente, no contrário, seria na revisão dessa lei, num embasamento mais forte, com vários profissionais, e também aqui, novamente, no aspecto multidisciplinar com os vários profissionais da área de assistência social, de psicologia, da área médica, de obstetrícia, e havendo um grande debate pra haver, assim, uma lei muito mais bem... Muito mais fundamentada.

$E$, depende do que a gente considera como direito, né, porque qual é o direito de cada um, né? A pessoa tem o direito de fazer uma coisa que vai prejudicá-la? Essa pessoa não tem, também, o direito de ser bem orientada, se ela tá mal orientada naquele momento, né? Então depende do que a gente considera direito. Tem, uma pessoa, o direito de estar mal orientada e fazer um procedimento definitivo em relação à sua vida reprodutiva? Eu não acho que isso seja um direito. Eu acho que o direito é de uma boa informação, então é isso que eu considero um direito dos pacientes. Os pacientes têm, sim, o direito de ser muito bem orientados, o que não são. Então eu não considero direito o fato de ir lá e você colocar a paciente numa mesa e ligar as tubas dela, eu não acho que isso é um direito, eu acho que direito... Eu acho que quem tem esse direito é uma paciente com hipertensão pulmonar, com uma cardiopatia grave, essa paciente tem $o$ 
direito porque ela tem o direito à vida, isso é constitucional, todos nós temos direito à vida. Então uma pessoa dessa que tem alto risco e tem risco de vida com uma gravidez, ela tem direito de ser esterilizada para não correr o risco de vida, aí sim, ela tem esse direito. $O$ resto tem o direito de ser muito bem orientada e pra fazer um procedimento correto, que seja mais, assim... Que seja mais adequado pra situação dela, né.

Pra mim são itens fundamentais: a idade, pra mim vinte e cinco anos é muito cedo. Eu considero a faixa entre vinte e oito a trinta e cinco anos, ou algo nesse intervalo, eu considero melhor do que vinte e cinco, e algo acima de três filhos eu também considero melhor em relação à prole, do que dois filhos, e patologias que aí realmente passa a ser um critério, que tem uma certa... Tem um peso maior do que os outros dois, porque mesmo às vezes com uma idade menos avançada, vamos pensar até na lei, nos vinte e cinco anos, se eu tiver uma paciente com hipertensão pulmonar e com filho único, eu não vou pensar duas vezes, eu indico a laqueadura, sem dúvida nenhuma, sem nenhum peso na consciência. (Eros, médico, 56 anos, trabalha em UBS, espírita praticante).

Eu acho que deveria de ser pelo menos o mínimo... Pelo menos de vinte e oito ou trinta anos, e pelo menos dois filhos saudáveis. E, não é ou. Porque se você abre mão disso eu acho que... Não sei, eu acho que é uma agressão. A gente tá falando sobre laqueadura, né, eu acho que é uma agressão ao corpo da mulher. Eu acho que não tem muito sentido você fazer isso só porque a mulher quer, a mulher deseja né, porque também abre mão pra outras coisas, né, DST, doenças sexualmente transmissível, HPV, HIV, né, gonorréia, sífilis. Então a gente abre espaço pra muita coisa. (Ares, médico, 46 anos, trabalha em UBS, católico praticante).

$\mathrm{Na}$ leitura de Aristeu, médico, a lei, embora discipline um pouco a prática profissional, notadamente em relação a abusos em relação à esterilização, precisa ser aperfeiçoada por ser restritiva, em alguns aspectos como é o caso da laqueadura pós-parto normal que necessitaria ser revista, é permissiva, em outros, como é o caso da idade de vinte e cinco anos, que considera bastante precoce para esse procedimento. Além do número de filhos e da idade mais tardia, que sugere seja de trinta anos, Aristeu considera igualmente importante que a lei 
possa contemplar outro critério social, qual seja, o da situação conjugal.

Eu diria assim, mais... É uma lei que foi feita à revelia, eu acho que houve muito pouca discussão entre os próprios médicos interessados, entre os psicólogos e o serviço de saúde. Foi imposta, né, a lei foi imposta, por isso que não é uma boa lei, eu acho. Mas ela disciplinou um pouco. Tem o lado positivo de disciplinar porque existia muito abuso, em relação dos médicos, mesmo.

Eu acho que eu restringiria muito essa questão de fazer laqueadura sem estar grávida, após vinte e cinco anos. Primeiro, o fator econômico mesmo. Assim, eu acho que é uma situação onde a pessoa não vai tomar um leite pra fazer uma laparotomia, enquanto que a gente tem situações de histerectomia, de... Que não consegue fazer tudo, e dar essa abertura pra fazer esse tipo de procedimento. Então não é prioridade, eu acho, no serviço público. Porque a prioridade é a vasectomia, então tem que direcionar pra vasectomia. Essa questão de fazer laqueadura sem estar grávida, após vinte e cinco anos, eu acho que poderia, até, ser suprimida, ou drasticamente, assim, digamos, é... Reprimida, né. Assim, ter o critério muito mais restrito, restringido. De você internar o paciente só pra laqueadura. Eu acho que não é muito válido, teria que ser muito restrito. Coisa que atualmente, mesmo... O que vem... Porque eu já sou contra, né. Eu nunca fiz, assim, você vê, trinta anos de... Eu nunca fiz uma paciente internar pra fazer a laqueadura. Eu acho assim, o fim da picada se fazer... Eu acho assim, que vinte e cinco anos é uma idade baixa, deveria ser a idade, se fosse aumentada, mais rigorosa. A lei é rigorosa num sentido e permissiva em outros. A idade é uma delas, eu acho. É muito cedo. Muito cedo. É muito permissiva. Quanto a idade... É..eu teria a sugestão de aumentar, por exemplo, pra trinta anos e dois filhos. Teria que se voltar e se estudar a possibilidade de laqueadura pós-parto normal, que é justo, inclusive na residência a gente fazia muito pras pacientes de multíparas. Tem o direito... Tem o lado social disso. Assim, agora porque que vai impedir uma paciente que não quer mais filhos, que com toda a avaliação médica, psicológica, já foi avaliado, impedir que ela tenha um parto normal, então não tá se onerando, não tá fazendo uma cesárea pra fazer laqueadura. Então ela vai ter o parto normal e uma pequena cirurgia depois, do que esperar seis meses pra depois internar novamente e fazer laqueadura. Isso, assim, eu já vou falar, o critério é mais pessoal meu, né. Agora, em relação... Eu não pensei, assim, em termos de 
saúde pública, em relação à grande população. Eu não tenho uma ideia fixa, mas no meu ponto de vista como conduta pessoal, mesmo, eu acho que é importante, é tão importante quanto o número de filhos e a idade, a situação conjugal.

A lei é essa comunicação com o SUS, né(notificação compulsória). É só isso daí que precisa haver uma facilidade nesse sentido, então até hoje eu não sei, eu já me informei com várias pessoas e ninguém sabe como faz isso. Eu nem sei se faz... É, mas os hospitais não têm né. Aí tá uma falha... O Ministério deveria cobrar essa responsabilidade dos hospitais. (Aristeu, médico, 54 anos, trabalha em UBS, católico praticante).

No discurso de Átropos, médica, mais uma vez se observa, na ampla narrativa abaixo apresentada, em que termos a lei se apresenta como possibilidades ou limites para a prática profissional, tirando do médico o que considera melhores possibilidades de decidir tendo em vista o melhor cuidado a ser oferecido ao paciente. Na sua leitura, a lei deveria contemplar as situações específicas de a esterilização ser realizada no momento do parto, quando existe a indicação de cesárea, como no caso clínico simulado pelo investigador que foi apresentado para os entrevistados, para efeitos de avaliação de situações concretas vivenciadas pelos mesmos. Entende, também, a necessidade de ser permitida a laqueadura pós-parto normal, além de destacar que cada caso deve ser individualizado e não analisado de uma forma generalizada, discurso que igualmente repõe, com novas colocações, a ideia de como devemos e/ou poderemos pensar e refletir sobre o exercício da prática médica no contexto da saúde pública que prevê, em suas políticas, leis que se aplicam em âmbito populacional:

Então, eu acho que... Em relação ao texto eu acho que essa coisa... Uma coisa que eu não concordo muito, por exemplo, é você ter que fazer o procedimento fora da cesárea, quer dizer, de um procedimento que a paciente já está lá internada no hospital e sob anestesia. Isso eu acho que inibe um pouco as pessoas de fazerem a esterilização, então eu acho que isso deveria ser revisto, em minha opinião. E também em relação à idade, vinte e cinco anos. Às vezes eu acho que uma pessoa de até vinte e cinco 
anos ou ter dois filhos vivos, ela não tem maturidade. O que a gente percebe muito em consultório, em ambulatório, é que elas se arrependem, casam novamente com outra pessoa. Então nesse sentido eu não concordo, apesar da lei, da idade ser vinte e cinco anos eu acho que é muito jovem pra ter esse tipo de escolha. Eu acho que ele podia ser um pouco mais esclarecedor, assim, no sentido do que ele realmente... Do que seria melhor pro paciente. Eu acho que ele teria que ter o consenso de alguns ginecologistas pra auxiliar na lei, né, então... E acho que em relação ao momento de ser feito, quer dizer, porque que eu tenho que esperar o puerpério e eu não posso fazer durante uma cesárea? Eu não "taria" aumentando o meu índice de cesárea? Acredito que não. Quer dizer, acho que isso aí... Acho que não muda muito isso, não sei se também a preocupação em relação à lei foi essa, mas acho que tem que pensar no melhor pro paciente, então a idade é um fator, assim, eu com quarenta e dois anos que vou fazer, sendo mãe, eu acho que a idade é um fator, porque a gente muda. Eu com vinte e cinco anos era uma pessoa, com trinta outra, com quarenta outra. E com a vivência de consultório você vê que as pessoas mudam também, então a idade é um fator que nem sempre você com vinte e poucos anos tem a idade. Então eu acho que não dá pra você generalizar todas as pacientes com uma lei. Eu acho que a gente... Eu sempre digo isso, a gente tem que individualizar cada caso, o paciente. Quer dizer, se eu tenho uma paciente de vinte e cinco anos e com cinco cesáreas eu vou fazer a laqueadura porque pra ela é melhor, se você tem uma paciente de vinte e oito anos com parto normal que quer fazer a laqueadura eu acho que não tem porque fazer uma laqueadura numa menina de vinte e oito anos, eu vou tentar convencê-la do contrário. Agora, acho que é um desejo do paciente também. Acho que a gente tem que levar em conta isso, também? Acho que também tem que ser levado em conta, mas fica difícil, talvez, com uma lei, eu generalizar pra todo mundo, né. Eu acho que esse é o grande problema da medicina, na medicina a gente não consegue, pra todo mundo, ser igual, a gente tem que tentar individualizar cada caso. Então não sei se vai existir uma lei perfeita algum dia, mas eu acho que alguns... Algumas coisas da lei estão erradas. Por exemplo, acho que essa coisa de não poder fazer no momento do parto, quer dizer, eu vou ter que submeter aquela paciente com um filho de três meses a uma nova anestesia, quer dizer... Então algumas coisas poderiam ser melhor 
colocadas.

Eu acho que deveria ter o direito de fazer esse no pós parto. Fazer uma laqueadura puerperal, eu acho que ela deveria ter esse direito. No momento que ela tá, já, no hospital, já tentar fazer. Acho que tem que individualizar mesmo, eu não consigo ver a medicina dessa forma, como uma lei, assim, em todos os casos. Quer dizer, nesses casos que você colocou, pra cada um eu teria uma postura, apesar de eu entender que na lei ela tem direito, né. (Átropos, médica, 41 anos, trabalha em Hospital, católica não praticante).

Nikê, médica, embora reconheça, em seu discurso, que a restrição colocada pela lei à realização do parto cesariano para fins de esterilização tenha sentido em termos geral, ou seja, em termos de saúde pública, considera que a esterilização cirúrgica deveria ser permitida no momento do parto, prevista em lei, quando a paciente tivesse passado pelo processo prévio de aprovação por parte da equipe multiprofissional. Em seu discurso, a idade de vinte e cinco anos é considerada precoce para esse procedimento, tendo em vista tanto as transformações e dinâmica da vida pessoal, quanto à questão da maturidade de uma jovem para uma decisão que possa vir a causar arrependimento e implicações para a vida futura. Daí incluir, igualmente, a sugestão de que a lei deva ser restritiva, ao lado da idade, também nos casos de ausência de vida conjugal:

Eu acho que essa é uma delas. Numa paciente que tem, já, um processo de aprovação e que você vai submetê-la a um ato cirúrgico, eu acho que você poderia aproveitar o momento do parto pra fazer, tá. Talvez tenha sentido essa restrição legal num âmbito geral. Eu acho que, realmente, não é o melhor momento pra mulher decidir se ela quer ou não ter mais filhos, mas eu acho que numa paciente que já existe um processo, que já houve um tempo pra, realmente, avaliar tudo aquilo, e que existe uma autorização realmente feita, eu acho que poderia alterar a lei nesse sentido. Ser mais permissiva, das pessoas que não tem capacidade civil plena. Isso. E até mesmo envolvendo nisso, questão de droga, questão de limitações.

Eu acho que poderia ser um pouco mais flexível a lei, também. Porque se 
por um lado você tá sendo invasivo no sentido de decidir pela pessoa, por outro lado ela também não tem uma decisão, ela não tem plena consciência quando ela tem um filho e tem que cuidar daquele filho de uma forma inadequada, né, ela não tem essa capacidade plena também pra estar...

Eu acho que o direito, ele, assim, ele sempre sabe como usar e como manipular o palavreado, então se as coisas não são extremamente claras você sempre vai poder usufruir do que te convir, dependendo do que você tá procurando, né. Então eu acho isso muito complicado. Você esterilizar uma moça de vinte e um anos, pra mim não faz o menor sentido. E assim, talvez eu até mudaria os vinte e cinco pra uma idade um pouquinho maior. Eu acho que, principalmente, se você... Acho que aí deveria ter mais exigências, tá. Aumentar o grau de exigência pra uma pessoa solteira poder se submeter a um ato cirúrgico desse tipo. Aí sim, uma avaliação psicológica muito maior. Ter uma... Ter algo que nos respaldasse melhor em relação a isso. A segurança da decisão. A maturidade, mesmo, dessa decisão. Eu acho que muito poucas pessoas têm essa capacidade de decidir de uma forma tão veemente que não quer. Eu acho que a vida é dinâmica, e assim, as circunstâncias são dinâmicas, e você pode mudar de opinião (Nikê, médica, 48 anos, plantonista, espírita praticante).

Afrodite, médica, aponta, como outros profissionais, a ambiguidade do texto da lei notadamente em relação á ideia mínima, mas podemos observar que a mesma restringe suas observações ao que podemos nomear como critérios sociais para a realização da esterilização, aos quais considera importante. Como em outros discursos anteriores, entende que a idade mínima deveria estar relacionada ao número de filhos, mas, igualmente, à situação conjugal. Nesse sentido, sua proposta para a reformulação da lei seria a de a mesma contemplar diferentes combinações, ou seja, para casos de casais sem união conjugal a idade mínima seria de 30 anos, e, nos casos de casais sem filhos, a idade mínima seria de 35 anos. Nos demais casos, a idade mínima seria de 25 anos e dois filhos vivos:

É a lei diz que ou tem que... Ou... A pessoa que tá pleiteando, né, seja ela homem ou mulher, independente da idade, ela tem que ter capacidade civil plena e pelo menos dois filhos vivos, ou então mais que vinte e cinco anos. $A$ 
minha forma de entendimento da lei é que se ela tiver... Se essa pessoa tiver mais do que vinte e cinco anos, que ela pode estar pleiteando o método definitivo. É o meu entendimento da lei, mas, particularmente, eu não concordo com essa, com essa idade limite pra pessoas sem nenhum filho. Eu já conversei com alguns colegas que entendem que é vinte e cinco anos e com, no mínimo, dois filhos, mas eu já li e reli várias vezes o texto e eu entendo da forma que eu citei anteriormente. Principalmente na questão da idade da mulher ou do homem que não tem filhos, e na questão da idade pra... Tanto pra mulher como pro homem que tem filhos, mas que não tem uma união conjugal.

A minha sugestão. A idade mínima pra quem não tem união conjugal seria trinta anos. Então assim, tem dois filhos vivos, mas não tem união conjugal, acima de trinta anos eu acho que seria bem razoável. E acima de quarenta, ou trinta e cinco, aí eu não tenho uma opinião muito... Eu teria que pensar um pouco mais, pra quem não tem filhos. Mas eu acredito que o mínimo seria trinta e cinco anos pra pessoas que não tem filhos. Eu acho que a idade mínima, mesmo pra quem tem filhos, ela está assim, muito baixa. Porque quando a gente lê o que eu entendo é que se ela tiver pelo menos dois filhos, independente da idade, aí acaba se caindo nessas situações de pessoas com vinte e um anos, nessa situação que você trouxe. Vinte e um anos com dois filhos, pela lei, seria possível. Então eu acho que a idade mínima, mesmo pra quem tem dois filhos e a uma união conjugal, seria de vinte e cinco anos (Afrodite, médica, 48 anos, trabalha em Hospital, católica não praticante).

Finalmente, o discurso de Hefesto, médico, no qual podemos observar que, similarmente aos de outros profissionais, há não somente o reconhecimento da ambiguidade da lei especialmente em relação ao parágrafo que versa sobre a idade de 25 anos ou 2 filhos vivos, mas, igualmente, uma preocupação e mesmo ênfase na discussão dessa questão, que consideramos um critério social, e não clínico, para a realização da esterilização . Embora mencione que a lei deveria incluir aquelas mulheres que não tenham duas cesáreas consecutivas para a realização da esterilização no momento do parto, Hefesto enfatiza e amplia a discussão da dimensão social contida no atual texto da lei, relativa à idade mínima 
e número de filhos, como critério para a realização da esterilização por mulheres e homens. Isto ao acrescentar não somente a menção à existência da relação conjugal, a exemplo do sugerido como novo critério nos discursos de outros profissionais que a lei deveria contemplar, mas também qualifica essa relação ao referir-se à mesma a partir da questão da estabilidade conjugal. Sugere, portanto, que no caso de uma revisão da lei a idade mínima deveria ser maior de 28 anos, o casal ter dois filhos vivos, além de uma relação conjugal estável.

É eu acho que isso seria uma das coisas pra arredondar, tá. No momento do parto, desde que tenha a indicação médica de se fazer. Ela não precisa ter cesárea nenhuma, tá, mas que a indicação seria médica, de resolução... Não pra fins de esterilização, mas sim pra fins médicos de realização. Isso é uma coisa que deveria ser arredondada, tá. A outra coisa seria a estabilidade conjugal ou a idade do paciente, porque às vezes você tem uma idade muito jovem e de repente você não tem uma estabilidade conjugal, tá, e aí de repente você pode ter até uma idade diferente, sem estabilização, sem o número de filhos, tá... Ah, "Em homens e mulheres com capacidade civil plena e maiores", "Com capacidade civil plena e maiores de vinte e cinco anos de idade ou pelo menos com dois filhos vivos", tá. É, esse parágrafo aqui, tá, ele acaba sendo muito confuso, que eu acho que grande parte das pessoas entendem esse ou como e. Que fala assim, "Olha, tem que ter vinte e cinco anos e tem que ter pelo menos dois filhos". Agora, é muito ruim, né, você tem vinte e seis anos, você pode. E aí você tem... Isso é ruim. Agora, você tem dois filhos com dezoito anos, dezessete anos, então você também pode? Então isso tá muito ruim na lei, então... Tá. Eu sugeria, tipo assim, um número de idade... Eu não sei, eu não sei te dizer, mas sei lá eu, eu acho que deveria ter pelo menos vinte e sete, vinte e oito anos de idade e com um número de filhos tipo, dois filhos, pelo menos, tá. Eu acho que essa palavra ou fica muito ruim, tá. Eu acho que se você tiver aí pelo menos vinte e sete anos de idade e dois filhos, além de tudo isso uma estabilidade conjugal, eu acho que é muito mais correto pelo que a gente tem de discernimento das coisas do que atuar numa maneira, nesse sentido que a lei fala dos vinte e cinco anos ou então ter dois filhos, ta. (Hefesto, médico, 57 anos, plantonista, católico não praticante). 
Como podemos observar, nos discursos relativos ao aperfeiçoamento da lei emergem nas narrativas dos vários profissionais não somente propostas, mas, igualmente, em que termos se colocam as controvérsias na interpretação da lei, dada, a ambiguidade do texto notadamente em relação ao parágrafo que versa sobre critérios que consideramos sociais para realizar a cirurgia, como é o caso da idade de 25 anos ou dois filhos vivos. Esse parágrafo, ao lado da questão da proibição da esterilização no momento do parto e no pós-parto imediato, apresenta-se como os aspectos que mais desafiam a aplicação da Lei 9263/196, em nível dos serviços de saúde. Daí podermos constatar que inúmeras são as propostas para o aperfeiçoamento da lei sugeridas pelos diversos profissionais em relação aos mesmos. 


\section{7- CONSIDERAÇÕES FINAIS}

A regulamentação da lei 9263/96, ao disciplinar a prática da esterilização cirúrgica, teve o mérito de incluir a mesma em condições de igualdade e liberdade de escolha entre todos os métodos de contracepção, no contexto do planejamento familiar, opção essa que não estava disponível a todos os usuários antes de sua regulamentação. Tal constatação encontra-se presente nos discursos de muitos dos profissionais entrevistados, independentemente da formação e do local de trabalho.

Outro mérito atribuído à regulamentação da lei, na fala dos profissionais em geral e enfatizada notadamente por profissionais médicos, foi a de disciplinar a prática médica, pois veio respaldar uma prática, que antes de sua normatização, era realizada indiscriminadamente, em um contexto de clandestinidade e ilegalidade, implicando na esterilização de casais muito jovens, por diferentes ordens de interesses de natureza econômica, política e ideológica.

Diferentemente dos outros métodos, a esterilização cirúrgica apresentou-se em nossa pesquisa como um procedimento bastante complexo quando comparado aos demais, na medida em que assume peculiaridades por envolver maturidade no processo de decisão por se tratar de um método definitivo, ou de difícil reversão, porque pode trazer implicações para a vida do casal, presente ou futura, notadamente em caso de arrependimento. Não se trata assim, de uma decisão individual e não reflexiva para projetos de vida futuros. Daí, nos discursos de muitos dos profissionais, a mesma dever ser prescrita como último recurso, constituindo a esterilização precoce num dos fulcros da discussão nos discursos dos profissionais no presente trabalho.

Nos referidos discursos ganha destaque o fato de a regulamentação da lei ampliar e garantir o acesso à esterilização cirúrgica a usuários pertencentes a diferentes estratos sociais, permitindo cumprir, assim, os princípios doutrinários do SUS, como a da Universalidade e Equidade, na medida em que antes este acesso era restrito às populações com maior poder aquisitivo. A ideia presente nesses 
discursos é a de que a esterilização cirúrgica vai além de uma simples retórica de direito, pois, trata-se um direito reclamável, deixando de ser, a autorização do procedimento, simples decisão dos profissionais de saúde, que antes empregavam critérios particulares, mais sujeitos às subjetividades de sua moral, de sua trajetória profissional, de sua religiosidade, de sua ideologia, portanto, de suas convicções pessoais.

Se, por um lado, essa posição em relação a subjetividades encontra-se presente nos discursos, em nível da retórica, acerca dos méritos da lei, por outro, quando os profissionais discursam sobre suas próprias práticas nos serviços de saúde em relação à aplicação da lei 9263/96, tal situação de subjetividade encontrase igualmente presente apontando para a constatação, que pudemos observar na presente pesquisa, acerca das controvérsias e desafios decorrentes da ambiguidade presente no texto da lei, que constituiu nosso problema central de investigação.

Em relação às possibilidades e limites na aplicação da lei, em termos de recursos ou disponibilidade da ampla gama de contraceptivos existentes, os discursos revelaram que, nos serviços de saúde, onde esses profissionais trabalham, os usuários são orientados sobre todos os métodos contraceptivos, entretanto, os métodos modernos como os implantes transdérmicos, anéis vaginais, adesivos dérmicos, dispositivos intra-uterinos (DIU) medicados e pílulas vaginais não estão disponíveis para os mesmos na rede pública de saúde. Talvez este seja um dos obstáculos ao cumprimento da lei 9263/96, pois, conforme prescrito na mesma deveria ser oferecido pelos serviços, todos os métodos contraceptivos.

O processo de aprovação da esterilização cirúrgica, conforme prescrito na lei envolve o trabalho de uma equipe multidisciplinar comportando várias etapas tais como: o desencorajamento da esterilização cirúrgica precoce, a oferta de todos os métodos, o prazo de sessenta dias entre a manifestação da vontade e o procedimento, para cumprir os requisitos legais. Nos discursos dos profissionais podemos observar que o processo prescrito em lei, em relação ao trabalho de 
equipe multidisciplinar, não se apresenta, necessariamente, de maneira articulada, entre a decisão e execução. Daí ocorrer, muitas vezes, a não realização do procedimento, uma vez que, em última instância, a decisão é de domínio do médico executante, que não partilharia, no caso, da mesma visão e avaliação da equipe multidisciplinar, ou, da própria mulher, homem ou casal. Tal fato se deve, sobretudo, ao forte componente moral de que se reveste a prática da esterilização cirúrgica em nível dos serviços e nas subjetividades que orientam, em última instância, as decisões dos médicos executantes.

Assim, observamos em nosso trabalho que não somente a não disponibilidade de todos os métodos existentes dificultam, em nível dos serviços, a aplicação da lei, mas, igualmente a articulação da equipe multiprofissional em termos do processo de aprovação e execução, quando ocorre de maneira desarticulada, como presente na maioria dos discursos, representa aspecto de grande relevância para que a esterilização cirúrgica seja de fato praticada e reconhecida como um direito no contexto do planejamento familiar.

Em relação ao aspecto acima mencionado, destaca-se a importância dada pelos profissionais de saúde, da necessidade de avaliação da pessoa que solicita, em sua integralidade, por uma equipe multidisciplinar, com diferentes visões de mundo. No entanto, o que podemos observar nos discursos é o fato de alguns profissionais buscarem avaliar principalmente os dados considerados subjetivos, como a maturidade do indivíduo na sua tomada de decisão, enquanto que notadamente os médicos se centram mais nos chamados dados objetivos, melhor dizendo, aparentemente objetivos, como a idade, a paridade, e as questões de saúde. Assim sendo, a partir dos discursos podemos constatar que a esterilização cirúrgica assume no seu conjunto, um caráter de procedimento clínico e ao mesmo tempo um procedimento de intervenção social, na medida em que narrativas de alguns profissionais buscavam justificar a aprovação e realização da esterilização para minimizar as precárias condições sócio-econômicas de alguns casais, assim como, mulheres sem vida conjugal.

Em relação aos motivos pelos quais, casais, homens ou mulheres, 
escolhem a esterilização como método contraceptivo os profissionais entrevistados entendem que os mesmos decorrem de um conjunto de condições como o número de filhos, a questão econômica, os problemas de saúde, intolerância à utilização de outros métodos, intolerância que entendem influenciadas, muitas vezes, pela falta de conhecimento e tradicionalismo cultural, discursos esses concordantes com resultados presentes na literatura especializada. Nesses discursos, os profissionais entendem que a escolha da esterilização, por mulheres e homens é atribuída à sua alta eficácia, comodidade do uso do método, livrar-se, no caso das mulheres, da ingestão de medicamentos, além de outros motivos como o dos de cuidados médicos relativos a exames e consultas de controle, que também foi relatada. A escolha foi atribuída, igualmente, à vantagem do livre exercício da sexualidade, sem a preocupação com uma possível gravidez, embora com observações sobre o problema do esquecimento do uso de práticas de proteção contra doenças sexualmente transmissíveis.

Nos discursos sobre os critérios para tomada de decisão, pelas equipes, que passam obrigatoriamente pela interpretação da lei e suas controvérsias, é que

podemos melhor observar como a aplicação da lei encontra-se sujeita à subjetividade e aos valores pessoais de cada profissional. Os critérios como idade, número de filhos, estado conjugal, condição sócio-econômica assumem, em seus discursos, uma estreita intersecção entre a dimensão clínica com a social. Em tela permanece a questão da autonomia dos sujeitos, quer profissional, quer o usuário.

Sobre as concordâncias e divergências no processo de aprovação da esterilização, pelas equipes, alguns profissionais entendem que as mesmas ocorrem entre os próprios profissionais na interpretação da lei 9263/96. Nas Unidades Básicas de Saúde, observamos que o consenso é maior entre os profissionais, enquanto que as divergências ocorrem com maior frequência, em âmbito hospitalar, ou seja, no momento de sua execução. Ocorrem divergências ainda entre as equipes de saúde e os usuários, tanto em âmbito da aprovação da esterilização, como na sua execução, se transformando a aplicação da lei 9263/96 e a prática da esterilização cirúrgica, ao que parece em nosso meio, em um 
grande desafio.

Assim, a prática da esterilização cirúrgica, após sua regulamentação, pode ser vista, nos discursos dos profissionais, em termos de uso e abuso, de diferentes ordens, tais como: a ampla abertura da lei em relação ao parágrafo, que prescreve a esterilização para pessoas de 25 anos ou pelo menos dois filhos vivos, a banalização do procedimento sem a devida reflexão e análise de seus riscos; a prática baseada no desejo ou demanda de jovens que elegem a esterilização como de primeira escolha em detrimento dos métodos reversíveis; o planejamento familiar inadequado nas Unidades Básicas de Saúde, cujos profissionais não orientam adequadamente para a disponibilidade de opção para os diversos métodos contraceptivos; a prática profissional centrada em valores e ideologias próprias do profissional que executa a esterilização.

Aspecto a enfatizar, como contribuição do presente trabalho, é o fato da esterilização cirúrgica, embora considerada, em nível dos serviços de saúde, como caso clínico, nos discursos dos profissionais podemos observar que a mesma se apresenta, como uma prática caracteristicamente social, antes de médica. Isso notadamente nos casos de jovens, quando a interpretação da lei encerra ambiguidades na interpretação, controvérsias nas decisões e dilemas para a sua realização, uma vez que, na avaliação do caso, que apresentamos aos entrevistados como simulação de situações passíveis de serem vivenciadas, as narrativas dos profissionais evidenciam uma preocupação maior com problemas de natureza sócio-econômicas e culturais da mulher, homem ou do casal e não dos problemas de saúde propriamente ditos, como justificadores da decisão para a realização ou não do procedimento.

Nessa mesma perspectiva, podemos observar que, a exemplo da idade, 0 número de filhos e estado conjugal dividem as avaliações dos diferentes profissionais. Cabe destacar que a controvérsia na interpretação da lei em relação à idade mínima de 25 anos, a exemplo do que ocorre na literatura, também se encontra presente nos discursos dos profissionais. A preocupação constante de alguns dos profissionais em cumprir a lei, contrariando muitas vezes os seus 
valores pessoais, implicando o que podemos considerar como dilemas da prática profissional podem ser observados nos discursos. Assim, a questão do dilema, no caso da esterilização cirúrgica, apresenta-se notadamente quando o profissional tem que executar o procedimento em determinadas condições que vão contra seus princípios e valores morais e éticos. Para outros profissionais tal dilema não se apresenta na medida em que sua decisão é agir de acordo com a sua própria consciência, independentemente da lei.

Ao lado da idade, número de filhos e estado conjugal, outro aspecto que nos permite observar as ambiguidades e controvérsias em relação a lei, refere-se à realização da mesma no momento do parto e pós-parto. Como a lei não explicita a possibilidade de ser realizada a esterilização nos casos de a mulher não ter duas cesáreas consecutivas anteriores, cada profissional interpreta à sua maneira. Daí, conflitos com a lei estarem presentes na medida em que para beneficio do paciente, médicos procurariam evitar, de acordo com seus valores, visão de mundo e de ética profissional, uma nova anestesia, uma nova internação e uma nova intervenção cirúrgica para a mesma, portanto, contrariando, com isso, a própria lei. Assim, embora entendam que pela lei eles estão impedidos de realizar a esterilização, se arriscam, contudo, a cometer uma ilegalidade, assumindo muitas vezes a possibilidade de serem penalizados. Consideramos esses discursos reveladores, na medida em, que não identificamos colocações dessa ordem em nível da literatura especializada e tais aspectos se apresentam como relevantes, para se pensar, em nível das políticas públicas, o alcance e limitação da lei 9263/96.

Nesse particular inscreve-se a própria autonomia de que o médico dispõe no próprio processo de decisão para a realização de esterilização cirúrgica, quando realizada pelos chamados trâmites legais. Isto porque, muito embora em todo processo de avaliação a equipe multidisciplinar possua papel importante para subsidiar decisões médicas, o que podemos observar, notadamente em relação aos casos aqui relatados, é o de que, em última instância, a decisão pela realização ou não do procedimento caberá ao médico. Talvez, por isso, esse 
profissional se sinta confortável em decidir, independentemente de um processo anterior de avaliação, sobre transgredir ou não a lei em nome de sua própria avaliação pessoal e ética profissional.

Como podemos observar, nos discursos relativos ao aperfeiçoamento da lei emergem nas narrativas dos vários profissionais não somente propostas, mas, igualmente, em que termos se colocam as controvérsias na interpretação da lei, dadas as ambiguidades do texto notadamente em relação ao parágrafo que versa sobre critérios que consideramos sociais para realizar a cirurgia, como é o caso da idade de 25 anos ou dois filhos vivos. Esse parágrafo, ao lado da questão da proibição da esterilização no momento do parto e no pós-parto imediato, apresenta-se como os aspectos que mais desafiam a aplicação da Lei 9263/196, em nível dos serviços de saúde. Daí podermos constatar que inúmeras são as propostas para o aperfeiçoamento da lei, sugeridas pelos diversos profissionais, destacando-se, por um lado, a permissão no pós-parto imediato e no momento do parto da realização da esterilização e, por outro, a definição de uma idade mínima, com sugestões para que seja maior que 25 anos, visando minimizar o risco de arrependimento diante de projetos futuros de jovens mulheres, homens e casais. No entanto, nossa pesquisa revela a complexidade da questão social envolvida na esterilização cirúrgica que se apresenta em relação à idade mínima, assim como ao número de filhos. Isto porque, nos discursos de alguns profissionais, na revisão da lei a situação conjugal da mulher deveria ser incluída como um critério, para aprovação do procedimento, combinando idade mínima, número de filhos e situação conjugal pelo risco que supostamente a esterilização em uma mulher poderia ocasionar em termos futuros.

Finalmente, aspecto que se descortina a partir da análise dos discursos, e que consideramos relevante, refere-se ao fato de tais ambiguidades, controvérsias e dilemas observados em relação à aplicação da lei emergir, nas falas, ao que parece, em função de tal atividade tratar-se de uma ação de saúde pública que envolve a prática médica como uma das atividades para sua realização, e não de uma prática médica em si mesma, praticada como ato médico senso estrito. 
O que podemos visualizar, a partir das narrativas dos profissionais entrevistados, é a importância de que discussões mais aprofundadas, em nível das pesquisas em Saúde, tomem como objeto de investigação as relações entre prática médica e prática de saúde pública e, como a primeira, se reveste de novo significado, quando incorporada em nível de ações de saúde pública propriamente dita voltada a populações ou grupos populacionais. A questão presente é a de que tal prática implica cumprimento de políticas públicas, que não estão voltadas a indivíduos ou casos tipicamente clínicos, no qual o profissional médico sempre manteve autonomia, ou seja, sua atividade com características de profissional liberal. Daí a tônica de muitos dos discursos, médicos e não médicos, relativos às dificuldades de aplicação da lei da esterilização, dada sua generalização para a população brasileira como um todo, independentemente das diferenças regionais e também de classe.

Daí decorre aspecto que consideramos importante a partir da presente pesquisa, como contribuição ao estudo do tema das Políticas Públicas notadamente no campo da Saúde das Mulheres. Trata-se da constatação de que embora os direitos sexuais e os direitos reprodutivos da mulher, do homem e do casal, estejam previstos na Lei 9263/96, esses não são necessariamente respeitados, no processo de aplicação da lei em nível de serviços de saúde, uma vez que, podemos observar pelos discursos de profissionais que, mesmo obedecendo aos critérios e tendo a aprovação da equipe multidisciplinar, a decisão final fica centralizada no poder médico e, dentre esses profissionais, por motivos de diferentes ordens, não há consenso na aplicação da Lei. 


\section{8 - REFERÊNCIAS}

ALVARENGA, A.T. e SCHOR, N. Contracepção feminina e política pública no Brasil: pontos e contrapontos da proposta oficial. Saúde Soc., São Paulo, v. 7, n. 1, p. 87-110, jan/jul. 1998.

ÁVILA, B.A. Direitos Sexuais e Reprodutivos: desafios para as políticas de saúde.

Cad. Saúde Pública, Rio de Janeiro; v.19, n. 2, p. 465-469, 2003. Suplemento.

BARATA L.R.B. e col. Por um processo de descentralização que consolide os princípios do Sistema Único de Saúde. Epidemiol. Serv. Saúde, Brasília, v. 13, n. 1: p.15-24, mar. 2004.

BARBOSA, L.F. e col. Arrependimento após esterilização feminina no Brasil.

Rev. Bras. Saúde Matern. Infant., Recife, v. 9, n.2, p. 179-188, abr./Jun.2009 BERQUÓ, E. Brasil, um caso exemplar- anticoncepção e partos cirúrgicos - a espera de uma ação exemplar. Estud. Fem. Florianópolis, v.1, n. 2, p.366-381, Jul. 1993.

BARBOSA, R.M e KNAUTH D.R. Esterilização feminina, AIDS e cultura médica: os casos de São Paulo e Porto Alegre, Brasil. Cad. Saúde Pública, Rio de Janeiro, v. 19, p. 365-376, 2003. Suplemento 2.

BERQUÓ, E. e CAVENAGHI, S. Direitos reprodutivos de mulheres e homens face à nova legislação sobre esterilização voluntária. Cad. Saúde Pública, Rio de Janeiro, v.19, p.441-53, 2003. Suplemento 2.

BERQUÓ, E. e CAVENAGHI, S. Mapeamentos sócio-econômico e demográfico dos regimes de fecundidade no Brasil e sua variação entre 1991 e 2000. In: ENCONTRO NACIONAL DE ESTUDOS POPULACIONAIS 14. 2004, ABEP, Caxambú - Minas Gerais.

BRASIL, Lei $n^{\circ}$ 9.263, de 12 de janeiro de 1996. Regula o $\S 7^{\circ}$ do art. 226 da Constituição Federal, que trata do planejamento familiar, estabelece penalidades e dá outras providências. Diário Oficial da União; Brasília, DF, 15 jan.1996. Seção 1.

BRASIL. Portaria n‥ 144, de 20 de novembro de 1997. Diário Oficial da União, 
Brasília, DF, 24 nov. de 1997.

BRASIL. Ministério da Saúde. Parto, aborto e puerpério: assistência humanizada à mulher. Brasília, DF; 2001.

BRASIL. Ministério da Saúde. Secretaria de Atenção à Saúde. Departamento de Ações Programáticas Estratégicas. Relatório de Gestão 2003 a 2006 - Plano Nacional de Atenção Integral à Saúde da Mulher. Brasília, DF;2007.

BRASIL. Ministério da Saúde. Pesquisa Nacional de Demografia e Saúde da Criança e da Mulher. PNDS 2006. Dimensões do processo reprodutivo e da Saúde da criança capítulo 5 Desigualdade socioeconômica na utilização de métodos anticoncepcionais no Brasil: uma análise comparativa com base PNDS 1996 e 2006. Brasília, DF; 2009.

BRASIL, Secretaria Especial de Políticas para Mulheres - Presidência da Republica. II Plano Nacional de Políticas para Mulheres. Brasília, DF,2008.

CAREGNATO, R.C.A. e MUTTI, R. Pesquisa Qualitativa: Análise de Discurso versus Análise de Conteúdo. Texto contexto Enferm, Florianópolis, v.15, n.4, p. 679-684, out/dez 2006.

CARVALHO, L.E.C. e col. Número ideal de filhos como fator de risco para laqueadura tubária. Cad. Saúde Pública, Rio de Janeiro, v. 20, n. 6, p. 15651574, nov./dez. 2004.

CARVALHO, L.E.C. e col. Esterilização cirúrgica voluntária na Região Metropolitana de Campinas, São Paulo, Brasil, antes e após sua regulamentação. Cad. Saúde Pública, Rio de Janeiro, v. 23, n. 12, p. 2906-16, dez. 2007.

CARVALHO, M.L.O e Schor N. Motivos de rejeição aos métodos contraceptivos reversíveis em mulheres esterilizadas. Rev Saúde Pública, São Paulo, v.39, n. 5, p.788-794, out. 2005.

COSTA, M.C. e col. Planejamento Familiar: a autonomia das mulheres em questão. Rev. Bras. Saúde Matern. Infant. Recife, v. 6, n. 1, p.75-84, jan./mar. 2006.

CUNHA, A.C.R. e col. Fatores associados ao futuro reprodutivo de mulheres desejosas de gestação após ligadura tubária. Rev. Bras. Ginecol. Obstet., 
Ribeirão Preto, v. 29, n. 5, p. 230-234, mai. 2007.

CURTIS, M.K. e col. Regret folowing female sterilization at a young age: a systematic review. Contracepcion, Amsterdã, v. 73, n. 2: p. 205-210, feb.2006.

DIAS-DA-COSTA, J.S. e col. Uso de métodos anticoncepcionais e adequação de contraceptivos orais na cidade de Pelotas, Rio Grande do Sul, Brasil: 1992 a 1999. Cad. Saúde Pública, Rio de Janeiro, v. 18, n. 1, p. 93-99, jan/fev. 2002.

DONNANGELO, M.C. e PEREIRA, L. Saúde e sociedade. São Paulo: Duas Cidades; 1976.

FARIAS, J.P.Q. e col. Prevenção da transmissão vertical do HIV: atitude dos

obstetras em Salvador, Brasil. Rev. Bras. Ginecol. Obstet., Rio de Janeiro, v. 30, n. 3, p. 135-141, mar. 2008.

FORREST, J.D. e FORDYCE, R.R. Women's contraceptive attitudes and use in 1992. Int. Fam. Plan. Perspect., New York, v. 25, n. 4, p.175-179, jul./aug. 1993. GLINA, S. e col. Vasectomia: Controvérsias. Rev. Hosp. Clin. Fac. Med. São Paulo, São Paulo, v. 41, n. 1, p.43-48, jan./fev. 1986.

HARDY, E. e col. Risk factors for tubal ligation, detectable before surgery. Contraception, Amsterdã, v. 54, n. 3, p.159-162, set. 1996.

HENTZ, A.S. Esterilização humana: aspectos legais, éticos e religiosos. Disponível em http://jus.uol.com.br/revista/texto/6544/esterilização-humana. Acessado em 25/04/2011.

MARCHI, N.M. Consequências da vasectomia entre homens submetidos à cirurgia em Campinas, São Paulo. 2006. 140 p. Tese (Doutorado em Saúde Pública) - Faculdade de Saúde Pública, Universidade de São Paulo, São Paulo. MARCOLINO, C. Planejamento familiar e laqueadura tubária: análise do trabalho de uma equipe de saúde. Cad. Saúde Pública, Rio de Janeiro, v. 20, n. 3, p. 771779, mai./Jun. 2004.

MARCOLINO, C. Representações de uma equipe de saúde acerca de planejamento familiar e esterilização feminina. Rev Esc Enferm USP, São Paulo, v. 38, n. 4, p.422-428, dez. 2004.

MARISCAL, I.D.O. Direitos Sexuais e Reprodutivos da Mulher. Ser Médico - 
revista do Conselho Regional de Medicina do Estado de São Paulo, São Paulo, v. 4, n.15, p. 2-9, abr./jun. 2001.

MINAYO, M.C.S. O desafio do conhecimento: pesquisa qualitativa em saúde. 8. ed. São Paulo: Hucitec, 2004.

MOREIRA, M.H.L. e ARAÚJO, J.N.G. Planejamento familiar: autonomia ou encargo feminino? Psicologia em Estudo, Maringá, v. 9, n.3, p. 389-398, set./dez. 2004.

OLIVEIRA, M.C. A família brasileira no Limiar do ano 2000. Estud. Fem., Florianópolis, v. 4, n. 1, p. 55-63, jan./jun. 1996

ORGANIZAÇÃO DAS NAÇÕES UNIDAS. IV Conferência mundial sobre a mulher. Rio de janeiro: Fiocruz, 1996.

OSIS, M.J.D. PAISM: um marco na abordagem da saúde reprodutiva no Brasil. Cad. Saúde Pública. Rio de Janeiro, v. 14, p.25-32, 1998. Suplemento 1.

OSIS, M.J.D. e col. Atenção ao planejamento familiar no Brasil hoje: reflexões sobre os resultados de uma pesquisa. Cad. Saúde Pública, Rio de Janeiro, v.22, n.11, p.2481-2490, nov. 2006.

OSIS, M.J.D. e col. Atendimento à demanda pela esterilização cirúrgica na Região Metropolitana de Campinas, São Paulo, Brasil: percepção de gestores e profissionais dos serviços públicos de saúde. Cad. Saúde Pública, Rio de Janeiro, v.25, n.3, p.625-634, mar. 2009.

PETERSON, H.B. Sterilization. Obstet. Gynecol., Philadelphia, v.111, n. 1, p.189203, jan. 2008.

RIGOTTO, R.M. As Técnicas de Relatos Orais e o Estudo das Representações Sociais em Saúde. Ciênc. Saúde Colet., Rio de Janeiro, v.3, n. 1, p. 116-130, jan. 1998.

SCAVONE, L. Direitos Reprodutivos, Políticas de Saúde e Gênero. In: Dar a Vida e cuidar da vida: feminismo e ciências sociais. São Paulo: UNESP, 2004. p. 55-68.

SOARES, V. Movimento feminista: paradigmas e desafios. Estud. Fem., Florianópolis, v. 2, p. 11-14, jan./jun. 1994. Edição especial. 
SPINK, M.J. Práticas Discursivas e Produção de Sentidos no Cotidiano: aproximações teóricas e metodológicas. 3. ed. São Paulo: Editora Cortez, 2004

UNITED NATIONS POPULATION DIVISION. World Contraceptive Use 2005.

Disponível em http://www.who.int/whosis/indicators/compendium/2008/3pcf/en/. Acessado em 03 de outubro de 2008

UNPFA- Fundo de População das Nações Unidas. Planejamento familiar no Brasil - 50 anos de história. Conclusões do evento comemorativo ao Dia Mundial de População no Brasil. Brasília, DF, 2008.

VIEIRA, E.M. A esterilização de mulheres de baixa renda em região metropolitana do sudoeste do Brasil e fatores ligados à sua prevalência. Rev. Saúde Pública, São Paulo, v. 28, n. 6, p.440-448, dez. 1994.

VIEIRA, EM. O arrependimento após esterilização feminina. Cad. Saúde Pública, Rio de Janeiro, v. 14, p. 59-68, 1998. Suplemento 1.

VIEIRA, E. M. e col. Características dos candidatos à esterilização cirúrgica e os fatores associados ao tipo de procedimento. Cad. Saúde Pública, Rio de Janeiro, v. 21 , n. 6, p. 1785-1791, nov./dez., 2005.

VIEIRA, E.M. O arrependimento após a esterilização cirúrgica e o uso das tecnologias reprodutivas. Rev. Bras. Ginecol. Obstet., Ribeirão Preto, v. 29, n. 5, p. 225-229, mai.2007.

VIEIRA, E.M. e SOUZA L. de. Acesso à esterilização cirúrgica pelo Sistema Único de Saúde, Ribeirão Preto, SP. Rev. Saúde Pública, São Paulo, v. 43, n. 3, p.398404, mai./jun.2009. 


\section{ANEXO I - Lei 9263}

\section{Presidência da República Subchefia para}

\section{Assuntos Jurídicos}

\section{LEI № 9.263, DE 12 DE JANEIRO DE 1996.}

Regula o $\S 7^{\circ}$ do art. 226 da Constituição Federal, que trata do planejamento familiar, estabelece penalidades e dá outras providências.

O PRESIDENTE DA REPÚBLICA Faço saber que o Congresso Nacional decreta e eu sanciono a seguinte Lei:

\section{CAPÍTULO I \\ DO PLANEJAMENTO FAMILIAR}

Art. $1^{\circ}$ O planejamento familiar é direito de todo cidadão, observado o disposto nesta Lei.

Art. $2^{\circ}$ Para fins desta Lei, entende-se planejamento familiar como o conjunto de ações de regulação da fecundidade que garanta direitos iguais de constituição, limitação ou aumento da prole pela mulher, pelo homem ou pelo casal.

Parágrafo único - É proibida a utilização das ações a que se refere o caput para qualquer tipo de controle demográfico.

Art. 3ㅇ O planejamento familiar é parte integrante do conjunto de ações de atenção à mulher, ao homem ou ao casal, dentro de uma visão de atendimento global e integral à saúde.

Parágrafo único - As instâncias gestoras do Sistema Único de Saúde, em todos os seus níveis, na prestação das ações previstas no caput, obrigam-se a garantir, em toda a sua rede de serviços, no que respeita a atenção à mulher, ao homem ou ao 
casal, programa de atenção integral à saúde, em todos os seus ciclos vitais, que inclua, como atividades básicas, entre outras:

I - a assistência à concepção e contracepção;

II - o atendimento pré-natal;

III - a assistência ao parto, ao puerpério e ao neonato;

IV - o controle das doenças sexualmente transmissíveis;

V - o controle e prevenção do câncer cérvico-uterino, do câncer de mama e do câncer de pênis.

Art. 4ㅇ $\mathrm{O}$ planejamento familiar orienta-se por ações preventivas e educativas e pela garantia de acesso igualitário a informações, meios, métodos e técnicas disponíveis para a regulação da fecundidade.

Parágrafo único - O Sistema Único de Saúde promoverá o treinamento de recursos humanos, com ênfase na capacitação do pessoal técnico, visando a promoção de ações de atendimento à saúde reprodutiva.

Art. 5 - É dever do Estado, através do Sistema Único de Saúde, em associação, no que couber, às instâncias componentes do sistema educacional, promover condições e recursos informativos, educacionais, técnicos e científicos que assegurem o livre exercício do planejamento familiar.

Art. 6ํㅡㄹ As ações de planejamento familiar serão exercidas pelas instituições públicas e privadas, filantrópicas ou não, nos termos desta Lei e das normas de funcionamento e mecanismos de fiscalização estabelecidos pelas instâncias gestoras do Sistema Único de Saúde.

Parágrafo único - Compete à direção nacional do Sistema Único de Saúde definir as normas gerais de planejamento familiar.

Art. $7^{0}$ - É permitida a participação direta ou indireta de empresas ou capitais estrangeiros nas ações e pesquisas de planejamento familiar, desde que autorizada, fiscalizada e controlada pelo órgão de direção nacional do Sistema Único de Saúde.

Art. 8ำ $\mathrm{A}$ realização de experiências com seres humanos no campo da regulação da fecundidade somente será permitida se previamente autorizada, fiscalizada e 
controlada pela direção nacional do Sistema Único de Saúde e atendidos os critérios estabelecidos pela Organização Mundial de Saúde.

Art. 9 Para o exercício do direito ao planejamento familiar, serão oferecidos todos os métodos e técnicas de concepção e contracepção cientificamente aceitos e que não coloquem em risco a vida e a saúde das pessoas, garantida a liberdade de opção.

Parágrafo único. A prescrição a que se refere o caput só poderá ocorrer mediante avaliação e acompanhamento clínico e com informação sobre os seus riscos, vantagens, desvantagens e eficácia.

Art. 10. Somente é permitida a esterilização voluntária nas seguintes situações: (Artigo vetado e mantido pelo Congresso Nacional - Mensagem $n^{\circ}=928$, de 19.8.1997)

I - em homens e mulheres com capacidade civil plena e maiores de vinte e cinco anos de idade ou, pelo menos, com dois filhos vivos, desde que observado o prazo mínimo de sessenta dias entre a manifestação da vontade e o ato cirúrgico, período no qual será propiciado à pessoa interessada acesso a serviço de regulação da fecundidade, incluindo aconselhamento por equipe multidisciplinar, visando desencorajar a esterilização precoce;

II - risco à vida ou à saúde da mulher ou do futuro concepto, testemunhado em relatório escrito e assinado por dois médicos.

$\S 1^{\circ}$ É condição para que se realize a esterilização o registro de expressa manifestação da vontade em documento escrito e firmado, após a informação a respeito dos riscos da cirurgia, possíveis efeitos colaterais, dificuldades de sua reversão e opções de contracepção reversíveis existentes.

$\S$ 2ํ É vedada a esterilização cirúrgica em mulher durante os períodos de parto ou aborto, exceto nos casos de comprovada necessidade, por cesarianas sucessivas anteriores.

§ 3ํNão será considerada a manifestação de vontade, na forma do $\S 1^{\circ}$, expressa durante ocorrência de alterações na capacidade de discernimento por influência 
de álcool, drogas, estados emocionais alterados ou incapacidade mental temporária ou permanente.

§ 4ํㅜ A esterilização cirúrgica como método contraceptivo somente será executada através da laqueadura tubária, vasectomia ou de outro método cientificamente aceito, sendo vedada através da histerectomia e ooforectomia.

$\S 5^{\circ} \mathrm{Na}$ vigência de sociedade conjugal, a esterilização depende do consentimento expresso de ambos os cônjuges.

§ 60 A esterilização cirúrgica em pessoas absolutamente incapazes somente poderá ocorrer mediante autorização judicial, regulamentada na forma da Lei.

Art. 11. Toda esterilização cirúrgica será objeto de notificação compulsória à direção do Sistema Único de Saúde. (Artigo vetado e mantido pelo Congresso Nacional) Mensagem $\mathrm{n}^{0}$ 928, de 19.8.1997

Art. 12. É vedada a indução ou instigamento individual ou coletivo à prática da esterilização cirúrgica.

Art. 13. É vedada a exigência de atestado de esterilização ou de teste de gravidez para quaisquer fins.

Art. 14. Cabe à instância gestora do Sistema Único de Saúde, guardado o seu nível de competência e atribuições, cadastrar, fiscalizar e controlar as instituições e serviços que realizam ações e pesquisas na área do planejamento familiar.

Parágrafo único. Só podem ser autorizadas a realizar esterilização cirúrgica as instituições que ofereçam todas as opções de meios e métodos de contracepção reversíveis. (Parágrafo vetado e mantido pelo Congresso Nacional) Mensagem $\mathrm{n}^{\circ}$ $\underline{928, \text { de 19.8.1997 }}$

\section{CAPÍTULO II}

DOS CRIMES E DAS PENALIDADES

Art. 15. Realizar esterilização cirúrgica em desacordo com o estabelecido no art. 10 desta Lei. (Artigo vetado e mantido pelo Congresso Nacional) Mensagem $n^{\circ}$ $\underline{928, \text { de } 19.8 .1997}$ 
Pena - reclusão, de dois a oito anos, e multa, se a prática não constitui crime mais grave.

Parágrafo único - A pena é aumentada de um terço se a esterilização for praticada:

I - durante os períodos de parto ou aborto, salvo o disposto no inciso II do art. 10 desta Lei.

II - com manifestação da vontade do esterilizado expressa durante a ocorrência de alterações na capacidade de discernimento por influência de álcool, drogas, estados emocionais alterados ou incapacidade mental temporária ou permanente; III - através de histerectomia e ooforectomia;

IV - em pessoa absolutamente incapaz, sem autorização judicial;

V - através de cesária indicada para fim exclusivo de esterilização.

Art. 16. Deixar o médico de notificar à autoridade sanitária as esterilizações cirúrgicas que realizar.

Pena - detenção, de seis meses a dois anos, e multa.

Art. 17. Induzir ou instigar dolosamente a prática de esterilização cirúrgica.

Pena - reclusão, de um a dois anos.

Parágrafo único - Se o crime for cometido contra a coletividade, caracteriza-se como genocídio, aplicando-se o disposto na Lei $n^{0} 2.889$, de $1^{\circ}$ de outubro de 1956.

Art. 18. Exigir atestado de esterilização para qualquer fim.

Pena - reclusão, de um a dois anos, e multa.

Art. 19. Aplica-se aos gestores e responsáveis por instituições que permitam a prática de qualquer dos atos ilícitos previstos nesta Lei o disposto no caput e nos $\S \S 1^{\circ}$ e 2ํำ do art. 29 do Decreto-lei oㅜ 2.848, de 7 de dezembro de 1940 - Código Penal.

Art. 20. As instituições a que se refere o artigo anterior sofrerão as seguintes sanções, sem prejuízo das aplicáveis aos agentes do ilícito, aos co-autores ou aos partícipes:

I - se particular a instituição: 
a) de duzentos a trezentos e sessenta dias-multa e, se reincidente, suspensão das atividades ou descredenciamento, sem direito a qualquer indenização ou cobertura de gastos ou investimentos efetuados;

b) proibição de estabelecer contratos ou convênios com entidades públicas e de se beneficiar de créditos oriundos de instituições governamentais ou daquelas em que o Estado é acionista;

II - se pública a instituição, afastamento temporário ou definitivo dos agentes do ilícito, dos gestores e responsáveis dos cargos ou funções ocupados, sem prejuízo de outras penalidades.

Art. 21. Os agentes do ilícito e, se for o caso, as instituições a que pertençam ficam obrigados a reparar os danos morais e materiais decorrentes de esterilização não autorizada na forma desta Lei, observados, nesse caso, o disposto nos arts. 159, 1.518 e 1.521 e seu parágrafo único do Código Civil, combinados com o art. 63 do Código de Processo Penal.

\section{CAPÍTULO III}

DAS DISPOSIÇÕES FINAIS Art. 22. Aplica-se subsidiariamente a esta Lei o disposto no Decreto-lei ํo 2.848, de 7 de dezembro de 1940 - Código Penal, e, em especial, nos seus arts. 29, caput, e $\S \S 1^{\circ}$ e $2^{\circ}$; 43, caput e incisos I, II e III ; 44, caput e incisos I e II e III e parágrafo único; 45, caput e incisos I e II; 46, caput e parágrafo único; 47, caput e incisos I, II e III; 48, caput e parágrafo único; 49, caput e $\S \S 1^{\circ}$ e $2^{\circ} ; 50$, caput, $\S 1^{\circ}$ e alíneas e $\S 2^{\circ}$; 51 , caput e $\S \S 1^{\circ}$ e $2^{\circ}$; $52 ; 56 ; 129$, caput e $\S 1^{\circ}$, incisos I, II e III, $\S 2^{\circ}$, incisos I, III e IV e $\S 3^{\circ}$.

Art. 23. O Poder Executivo regulamentará esta Lei no prazo de noventa dias, a contar da data de sua publicação.

Art. 24. Esta Lei entra em vigor na data de sua publicação.

Art. 25. Revogam-se as disposições em contrário.

Brasília, 12 de janeiro de 1996; 175ํ da Independência e 108 da República.

\section{FERNANDO HENRIQUE CARDOSO}




\section{ANEXO II - Roteiro Temático}

Instituição:

Número de identificação no estudo.

Data.

dia mês ano

Formulário para caracterização sócio-demográfica e profissional do entrevistado(a).

1- Profissão?

2- Idade?

3- sexo: $M() F()$

4- Quantos anos de atividade profissional?

5- Estado civil/ situação conjugal?

6- Têm filhos? ( ) sim ( ) não Quantos?

7- Religião?_ praticante? (. ) sim (. ) não

8- O Sr(aㅡ) gostaria de escolher algum "apelido" para se identificar na pesquisa?

( ) sim. Qual?

(. ) não.

Inicialmente, eu gostaria de agradecer o senhor(a) por participar deste estudo.

Devo dizer que tudo que o senhor(a) responder na entrevista será estritamente confidencial, e as informações colhidas dos vários participantes do estudo serão usadas apenas em relatos científicos, sem nenhuma identificação pessoal. E tudo que o $\operatorname{Sr}\left({ }^{a}\right)$ disser será de grande importância para o aperfeiçoamento dessa questão que envolve os profissionais de saúde. 
1. O que o $\operatorname{Sr}(\stackrel{a}{)})$ pensa da esterilização como método contraceptivo? Há quanto tempo o senhor trabalha com essa atividade?

RETER e EXPLORAR: se antes da lei já tinha prática favorável ou não à esterilização cirúrgica como método contraceptivo.

2. Quais os motivos pelos quais os casais escolhem este método?

3. O que o $\operatorname{Sr}(\stackrel{a}{)}$ achou da lei $9263 / 96$ que regulamentou esta prática nos serviços de saúde?

RETER e EXPLORAR: se a lei facilitou ou não o acesso à esterilização cirúrgica, se foi positivo, por quê?

4. O que o $\operatorname{Sr}(\stackrel{a}{)})$ achou do texto da lei?

RETER e EXPLORAR: a fala, as pistas, se achou o texto polêmico, no que achou polêmico? Concorda? Discorda?

5. Como é no seu serviço o processo para aprovação da esterilização?

6. Na sua experiência de equipe o que mais pesa no processo de decisão afirmativa ou negativa?

RETER e EXPLORAR: o que pesa mais se é o número de filhos, idade, solteira, casada, ou outras questões éticas, morais, etc.

7. Qual a importância que o $\mathrm{Sr}(\stackrel{a}{)})$ vê nos relatórios do psicólogo e da assistente social para subsidiar as decisões dos médicos?

8. Gostaria de retomar as suas impressões sobre as discussões relacionadas aprovação ou não da esterilização em sua equipe. Existem muitas opiniões diferentes? Quais são elas? Quais as mais frequentes ou preponderantes? 
9. $\mathrm{O} \mathrm{Sr}\left({ }^{a}\right)$ considera que a lei foi um avanço ou não? . Fale-me um pouco o que pensa dessa questão.

RETER e EXPLORAR: a sua própria opinião em relação à lei.

10. $\mathrm{O} \operatorname{Sr}\left({ }^{a}\right)$ acha que este tipo de lei atende a um direito das mulheres e dos homens?

11. O que o $\operatorname{Sr}(\stackrel{\text { a }}{)})$ acha desse procedimento ser feito pelo SUS ?

12. Vou fazer agora algumas simulações de situações de casos para que o $\operatorname{Sr}\left({ }^{(a}\right)$ comente sobre suas reflexões e possível conduta.

12.1. Se o $\operatorname{Sr}(\stackrel{a}{)})$ estivesse escalado para opinar na seguinte situação : Homem ou Mulher jovem, 21 anos de idade, com dois filhos vivos, com vida conjugal há 5 anos, que deseja contracepção definitiva através de laqueadura tubária ou vasectomia. O que o $\mathrm{Sr}\left({ }^{(}\right)$tem a dizer sobre as seguintes questões:

a- acha que a lei garante claramente o direito a esterilização cirúrgica ? b- $\mathrm{O} \operatorname{sr}(\stackrel{a}{)})$.aprovaria a realização do procedimento?

12.2. $\mathrm{Se} \circ \mathrm{Sr}\left({ }^{(a)}\right)$ estivesse escalado para opinar na seguinte situação: Homem ou mulher solteira com idade maior que 25 anos, sem filhos, que deseja contracepção definitiva através de esterilização cirúrgica. O que o $\mathrm{Sr}\left({ }^{(}\right)$tem a dizer sobre as questões abaixo:

a- $\mathrm{O} \operatorname{Sr}(\mathrm{a})$ acha que a lei garante claramente o direito a esterilização cirúrgica ? b- $\mathrm{O} \operatorname{sr}\left({ }^{a}\right)$.aprovaria a realização do procedimento?

12.3. $\mathrm{Se} \circ \mathrm{Sr}(\stackrel{a}{)})$ estivesse escalado para opinar na seguinte situação: Homem ou mulher com mais de 25 anos com 2 filhos vivos, sem vida conjugal opta pela esterilização cirúrgica. $\mathrm{O}$ que o $\mathrm{Sr}(\stackrel{\text { a }}{)}$ tem a dizer sobre as questões abaixo: 
a- $\mathrm{O} \operatorname{Sr}(\mathrm{a})$ acha que a lei garante claramente o direito a esterilização cirúrgica ? b- $\mathrm{O} \mathrm{sr}(\stackrel{a}{)})$.aprovaria a realização do procedimento?

12.4. Se o $\operatorname{Sr}(\stackrel{a}{)})$ estivesse e escalado para opinar na seguinte situação: Mulher que têm processo de laqueadura tubária autorizada pelo planejamento familiar, estando gestante, sem cicatriz de sucessivas cesáreas anteriores, que porventura tenha indicação médica de cesárea no momento do parto está impedida de ter a sua laqueadura realizada durante o parto.

a- Em sua opinião estará impedida de realizar o procedimento?

b- Se não estiver impedida o por quê?

13. $\mathrm{O} \operatorname{Sr}\left({ }^{a}\right)$ acha que esta lei poderia ser aperfeiçoada? Se sim, em que sentido e quais suas sugestões?

14. O senhor tem mais alguma questão que considera relevante sobre a lei que poderia enriquecer mais esse tipo de discussão?

\section{OBRIGADO POR SEU TEMPO E ESFORÇO EM CONCEDER A ENTREVISTA!}




\section{ANEXO III: Termo de Consentimento Livre e Esclarecido Projeto: A esterilização cirúrgica no Brasil, controvérsias e desafios na interpretação e aplicação da Lei 9263.}

Pesquisador: Sergio Toshio Yamamoto

Estamos realizando um estudo sobre A esterilização cirúrgica no Brasil, controvérsias e desafios na interpretação e aplicação da Lei 9263.

(que se encontra em anexo)

Se você aceitar o convite e concordar em participar voluntariamente do estudo:

1- Será entrevistado pelo pesquisador, com perguntas sobre dados pessoais e sobre o texto da lei 9263/96 e algumas situações que ocorrem, em relação a solicitação de esterilização, aprovação e execução do procedimento na prática do dia a dia no contexto do planejamento familiar. Esta entrevista será gravada e transcrita posteriormente.

2- O roteiro temático para a entrevista é composto por 14 questões abertas

3- $\mathrm{Se}$ o $\mathrm{Sr}\left({ }^{a}\right)$ se sentir desconfortável em responder qualquer uma das perguntas da entrevista poderá se recusar a respondê-la e a qualquer momento desistir de continuar a sua entrevista.

4- De acordo com as normas estabelecidas pela resolução 196/96 do Conselho Nacional de Saúde (Ministério da Saúde 1996), os participantes do presente estudo receberão informações sobre o mesmo, sendo que sua participação será voluntária. Os sujeitos, que mediante explicação dos objetivos da pesquisa, concordarem em fazer a entrevista terá a privacidade e o sigilo garantidos, assim como a liberdade de desistir a qualquer momento, sem qualquer prejuízo do entrevistado.

\section{Confidencialidade:}

Sua participação no estudo e informações sobre o senhor(a) será mantida sob sigilo. Qualquer registro ou não será divulgado a ninguém, além dos pesquisadores. 
Sua participação é voluntária. Os dados obtidos serão publicados em trabalhos científicos em periódicos e congressos. Se o fizermos, não vamos usar o seu nome ou qualquer outra coisa que faria com que as pessoas saibam quem você é.

\section{Como você pode começar?}

Se você decidir que vai participar do estudo, você assinará este Termo de Consentimento Livre e Esclarecido, isto é, depois de entender as razões e condições do estudo e as aceitar.

Gostaria de esclarecer que o $\operatorname{Sr}(\stackrel{a}{)})$ não terá ressarcimento de despesas referentes a alimentação e transporte e outros benefícios para participar deste estudo, e também nenhum prejuízo inclusive quanto sua estabilidade no seu emprego, em não aceitar a ser voluntário para participar desta pesquisa.

Você receberá uma cópia do Consentimento Livre e Esclarecido assinado pelo investigador.

\section{Quem contatar:}

O senhor(a) poderá fazer perguntas no caso de dúvidas sobre o projeto de pesquisa agora ou futuramente e poderá entrar em contato a qualquer momento com:

Dr. Sergio Toshio Yamamoto (pesquisador)

Hospital Maternidade Leonor Mendes de Barros. Fone: 2694-1999 ou 92442527

Se o Senhor(a) tiver dúvidas ou alguma denúncia quanto as questões éticas poderá a qualquer momento entrar em contato com:

Comitê de Ética em Pesquisa da Faculdade de Saúde Pública da Universidade de São Paulo

Av. Dr. Arnaldo, 715 Cerqueira César São Paulo - SP

Caixa Postal: 01246-904 Tel. (11) 30617779e-mail:coep@fsp.usp.br.

Comitê de Ética em Pesquisa da Secretaria Municipal de Saúde-CEP/SMS

Rua General Jardim, 36 - $1^{\circ}$ andar

Fone: 33972646/Fax: 33972465e-mail:smscep@gmail.com 
Comitê de Ética em Pesquisa do Hospital Maternidade Leonor Mendes de Barros pelo telefone 2292-4188 ramal 278.

Nome Participante:

Assinatura:

Data: / /

Nome do Pesquisador: Sergio Toshio Yamamoto

Assinatura:

Data: / / 